\title{
BALANCO DE NUTRIENTES EM UM SISTEMA AGROFLORESTAL NO CERRADO DE BOTUCATU, SP
}

\author{
ÁLVARO LUIZ MAFRA
}

Engenheiro Agrônomo

Orientador: Prof. Dr. ANDREAS ATTILA DE WOLINSK MIKLÓS

\begin{abstract}
Dissertação apresentada à Escola Superior de Agricultura "Luiz de Queiroz", da Universidade de São Paulo, para obtenção do título de Mestre em Agronomia, Área de Concentração: Solos e Nutrição de Plantas.
\end{abstract}

P I R A C I C A B A

Estado de São Paulo - Brasil

Agosto - 1996 
Dados Internacionais de Catalogação na Publicação (CIP) DIVISÃo DE BIBLIOTECA E DOCUMENTAÇĀ́O - Campus “Luiz de Queiroz"/USP

Mafra, Älvaro Liuiz

Balançode nutrientes em um sistema agroflorestal no cerrado de Botucatu, SP / Álvaro Luiz Mafra. - - Piracicaba, 1996.

65p. : il.

Dissertaçāo (mestrado) - Escola Superior de Agricultura Luiz de Queiroz, 1996.

Bibliografia.

1. Matéria orgânica do solo 2. Nutriente em solo 3. Sistema agrofloretal Balanço de nutrientes I. Título 


\title{
BALANCO DE NUTRIENTES EM UM SISTEMA AGROFLORESTAL NO CERRADO DE BOTUCATU, SP
}

\author{
ÁLVARO LUIZ MAFRA
}

Aprovada em: 26.08.1996

Comissão julgadora:

Prof. Dr. Fábio Poggiani

ESALQ/USP

Dr. Marco Antônio Ferreira Gomes

EMBRAPA/CNPM/Jaguariúna-SP

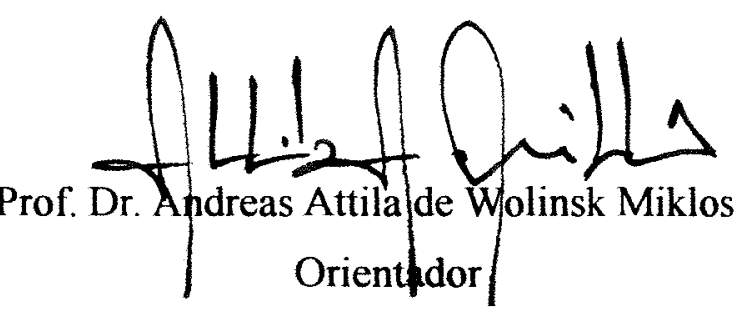




\section{AGRADECIMENTOS}

- Ao Prof. Andreas Attila de Wolinsk Miklós, pelos ensinamentos e amizade;

- Ao Departamento de Ciência do Solo, pela oportunidade de realização da pósgraduação;

- Aos professores Hilton Thadeu Zarate do Couto e Paulo Cesar Ocheuze Trivelin, pelo auxilio no planejamento do experimento;

- A Fundação de Amparo à Pesquisa do Estado de São Paulo (FAPESP), pelo financiamento concedido ao projeto;

- À Coordenação de Aperfeiçoamento de Pessoal de Nível Superior (CAPES), pela concessão da bolsa;

- Ao Instituto Biodinâmico de Desenvolvimento Rural (IBD), em especial ao Dr. Alexandre Ilumberto llarkaly pela concessão da area expermental e pelas lacilidades

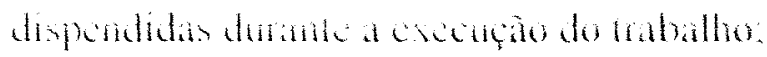

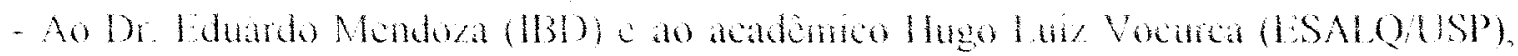
jelo auxilio ma condeção do experimento.

- Aos colcgas da bSALO pela amiado

- Aos familiares, polo estímulo e compreensão. 


\section{SUMÁRIO}

Página

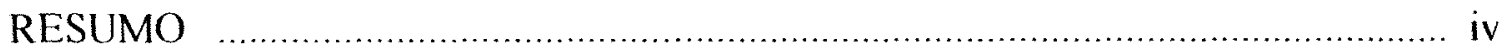

SUMMARY

1. INTRODUÇÃO

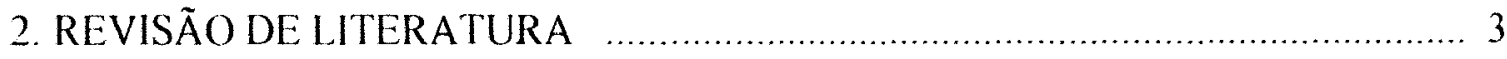

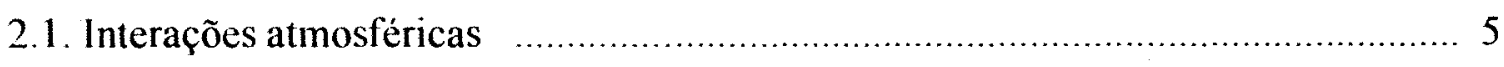

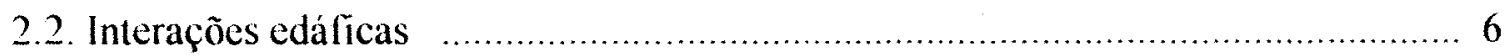

3. MATERIAL E METTODOS …

3.1. Caracterização da área experimental ................................................ 10

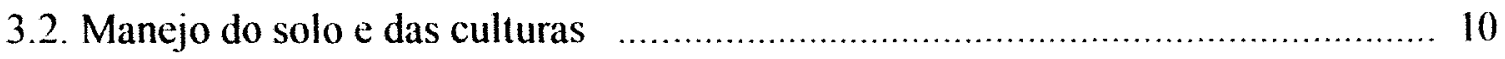

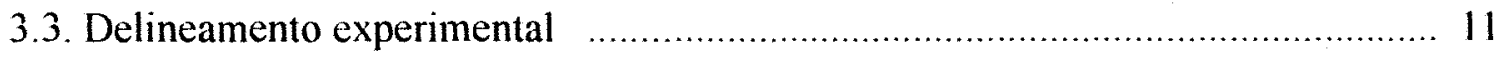

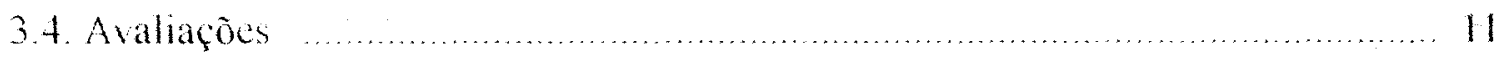

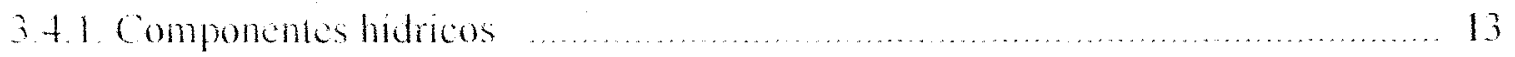

3.2. Componentes vegetais .................................................... 15

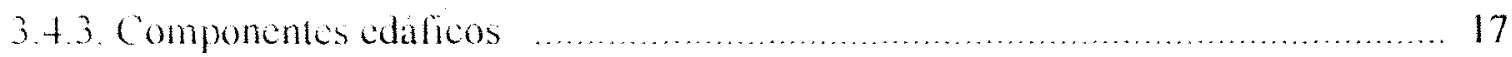

3.4 .4 lestimativa do balanço de nutrientes ............................................... 17

3.5. Análise dos resultados ............................................................ 19

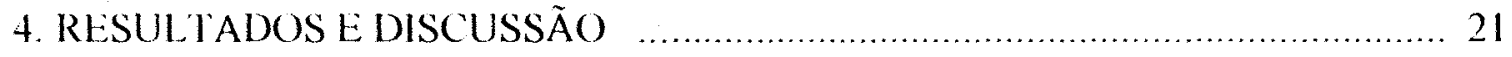

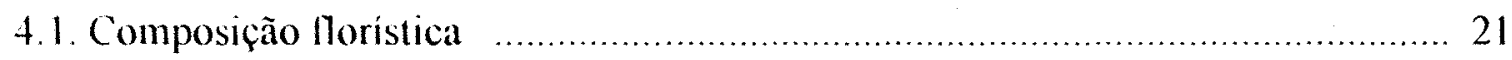

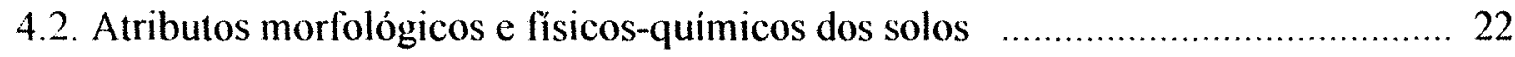

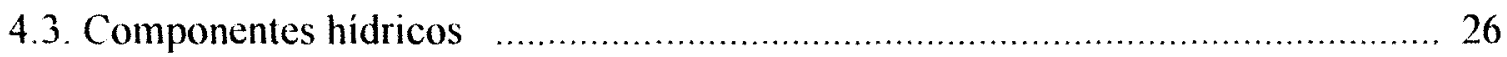

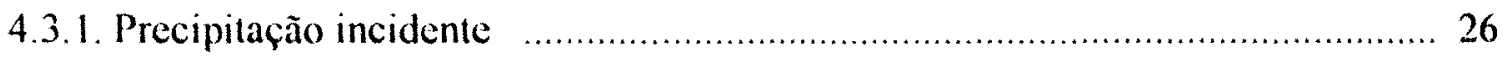

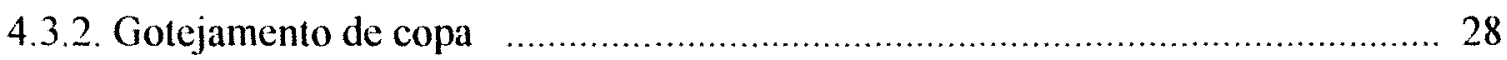

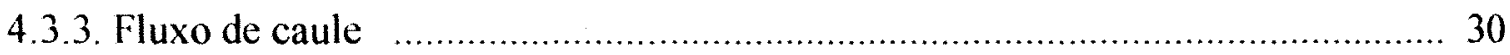

4.3.4. Interceptação

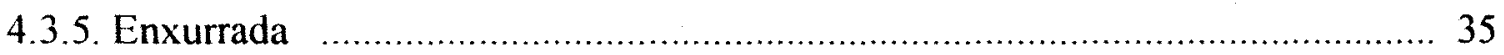

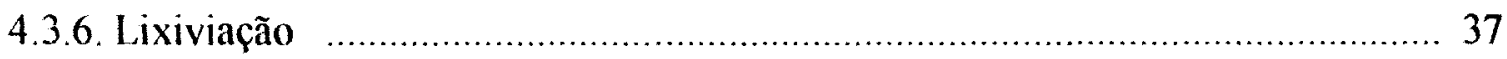

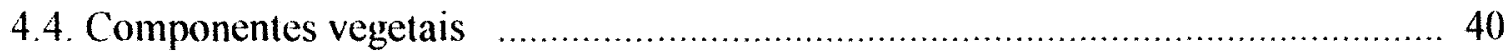

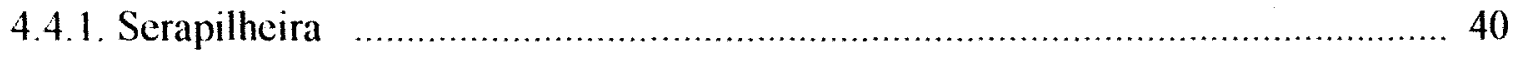




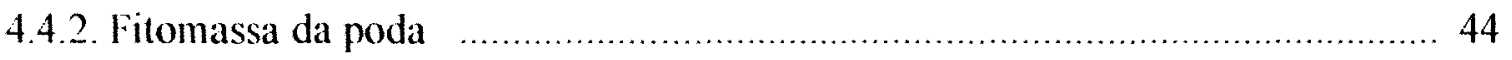

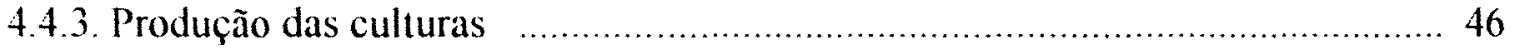

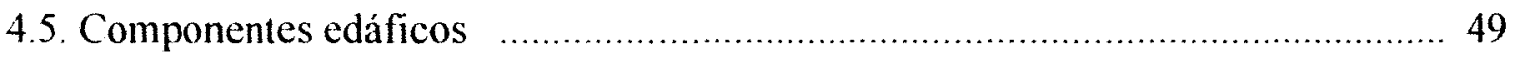

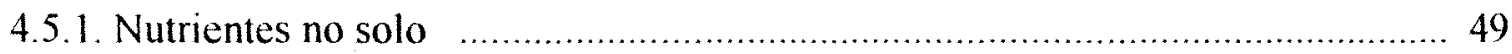

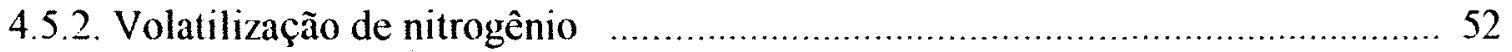

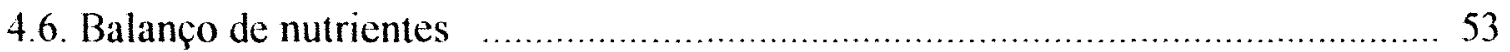

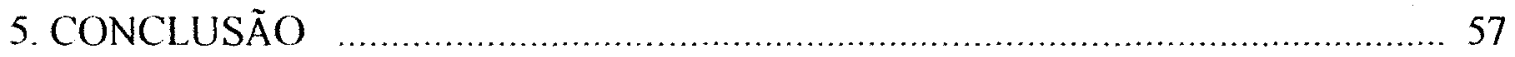

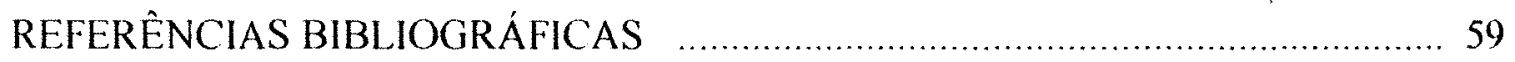




\title{
BALANCO DE NUTRIENTES EM UM SISTEMA AGROFIORESTAL NO CERRADO DE BOTUCATU, SP
}

\author{
Autor: ÁIVAROIUUZ MAFRA \\ Orientador: PROF. DR. ANDREAS ATILLA DE WOLINSK MIKLÓS
}

\section{RESUMO}

O cultivo em aléias é um tipo de sistema agroflorestal em que, as espécies arbóreas, plantadas em renques, são associadas com culturas anuais. Nesse sistema e no corrado, determinou-se o balanço de nutricntes a fim de verilicar o cleito

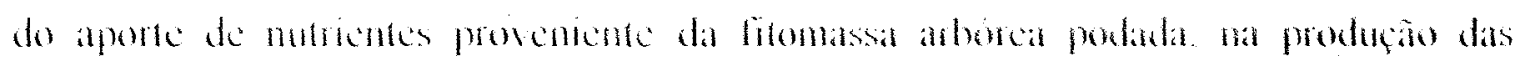

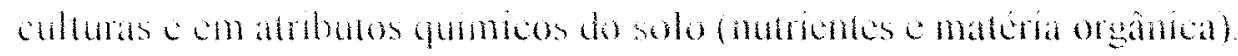

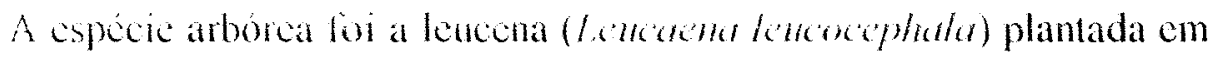
1987. em solo de cerrado (latossolo vermelho amarclo). Os rencus loram espaçados de $6 \mathrm{~m}$, com poda a cada 24 meses. Os cultivos anuais foram: aveia preta + centeio (inverno), usados como adubo verde e milho + feijão adzuki (verão). Aplicou-se adubação mineral somente na implantação da leucena.

As entradas e saídas anuais de macronutrientes foram avaliadas de junho de 1995 a maio de 1996 nos dois sistemas. Os componentes vegetais considerados foram: serapilheira, fitomassa podada da leucena, restos culturais e produção de grãos. Os componentes hídricos foram: chuva livre, gotejamento de copa, fluxo de caule, lixiviação e erosão. O teor de nutrientes no solo e volatilização de $\mathrm{N}$ também foram medidos. O balanço foi calculado pela diferença entre a adição e as perdas externas de nutrientes. Quantificou-se ainda a reciclagem interna de nutrientes para os componentes hídricos e vegetais.

As perdas de nutrientes no cerrado totalizaram $6,9 \mathrm{~kg} \mathrm{ha}^{-1}$ de $\mathrm{N}, 1,5 \mathrm{~kg}$ $\mathrm{ha}^{-1}$ de $\mathrm{P}, 4,7 \mathrm{~kg} \mathrm{ha}^{-1}$ de $\mathrm{K}, 28,4 \mathrm{~kg} \mathrm{ha}^{-1}$ de $\mathrm{Ca} \mathrm{e} \mathrm{4,9} \mathrm{kg} \mathrm{ha}^{-1}$ de $\mathrm{Mg}$. A lixiviação foi mais 
importante, contribuindo com 46 a $96 \%$ do total. As perdas por escoamento superficial foram minimas. No cultivo em aléias, as perdas de nutrientes atingiram $28,3 \mathrm{~kg} \mathrm{ha}^{-1} \mathrm{de}$ $\mathrm{N}, 5,5 \mathrm{~kg} \mathrm{ha}^{-1}$ de $\mathrm{P}, 13,3 \mathrm{~kg} \mathrm{ha}^{-1}$ de $\mathrm{K}, 36,2 \mathrm{~kg} \mathrm{ha}^{-1}$ de Ca e 6,1 $\mathrm{kg} \mathrm{ha}^{-1}$ de $\mathrm{Mg}$. Foram maiores que no cerrado, devido à remoção pelos grãos.

A reciclagem no ciclo planta-solo no cerrado, ocorreu principalmente pela serapilheira, com $2176 \mathrm{~kg} \mathrm{ha}^{-1} \mathrm{ano}^{-1}$ de fitomassa seca. Este componente teve 27,8 $\mathrm{kg} \mathrm{ha}^{-1}$ de $\mathrm{N}, 7,2 \mathrm{~kg} \mathrm{ha}^{-1}$ de $\mathrm{K}$ e $3,7 \mathrm{~kg} \mathrm{ha}^{-1}$ de $\mathrm{Mg}$, contribuindo com 64 a $83 \%$ do total desses nutrientes. Para o P e Ca, o maior retorno ao solo foi pelo gotejamento de copa, com 3,0 kg ha ${ }^{-1}$ de P e 14,9 $\mathrm{kg} \mathrm{ha}^{-1}$ de Ca. No cultivo em aléias, os componentes vegetais foram mais importantes, produzindo $11039 \mathrm{~kg} \mathrm{ha}^{-1}$ por ano de matéria seca. Deste total, $4465 \mathrm{~kg} \mathrm{ha}^{-1}$ foi composto de fitomassa podada, $4176 \mathrm{~kg} \mathrm{ha}^{-1}$ de restos culturais e $2398 \mathrm{~kg} \mathrm{ha}^{-1}$ de serapilheira. Como resultado a reciclagem foi 2,9 a 7,0 vezes superior à do corrado.

Conscquentemente obalanço amal de mutrientes no corado boi de 8,5

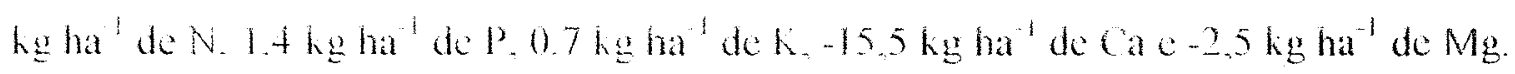
No sistema agroflorestal, o saldo anual de nutrientes atingiu $-12,8 \mathrm{~kg}$ ha de $\mathrm{N},-2,6 \mathrm{~kg}$

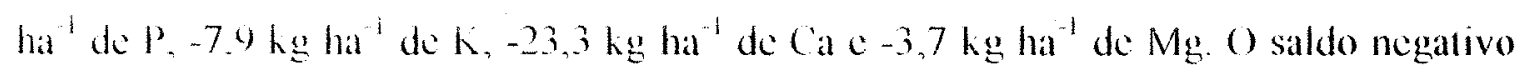
representa perda liquida de nutrientes, empobrecendo gradativamente o solo.

Os principais benefícios do cultivo em aléias, comparados ao cerrado, foram incrementos nos teores de carbono, N, P, Ca e Mg na camada superficial do solo $(0-20 \mathrm{~cm})$. Isso foi possivel, graças à reciclagem continua.

Apesar da melhoria nos teores de nutrientes e matéria orgânica no solo, a produtividade das culturas foi baixa: $1210 \mathrm{~kg} \mathrm{ha}^{-1}$ de milho e $175 \mathrm{~kg} \mathrm{ha}^{-1} \mathrm{de}$ feijão. Isto foi atribuído à competição exercida pela leucena e ao limitado conteúdo de nutrientes no solo, os quais, excetuando-se o $\mathrm{N}$, estavam em niveis baixos a muito baixos.

O cultivo em aléias pode ser indicado para a produção de alimentos sem a aplicação rotineira de fertilizantes. Isto resultará em economia de insumos para o agricultor. A adubação complementar com fósforo e potássio irá aumentar a produtividade das culturas e ajudará a equilibrar o balanço de nutrientes. 


\title{
NUTRIENT BUDGET IN AN AGROFORESTRY SYSTEM IN THE "CERRADO" OF BOTUCATU, SP
}

\author{
Author: ÁLVARO LUIZ MAFRA \\ Adviser: PROF. DR. ANDREAS ATILLA DE WOLINSK MIKLÓS
}

\section{SUMMARY}

Alley cropping is a kind of agroforestry system where tree species planted in hedgerows are associated with annual crops. In this system and in the cerrado, the nutrient budget was delemined, to find the effect of nutrient imput from pruned

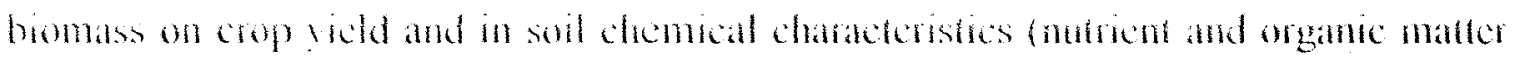
lats

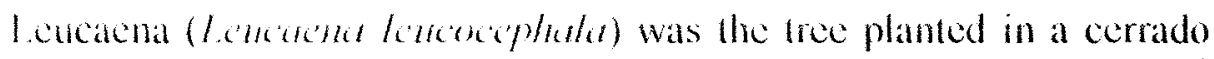
soil (1)aplortox), in 1987. The hedgerows were 6 ap apt and the proming interval was 24 months. Annual crops were oat + rye consorcialed in winter for green manuring. Maize + adzuki bean were grown in the summer. Mineral fertilizers were applied to leucaena at planting time but not to the cereal crops.

Annual nutrient inputs and outputs (from July/1995 to May/1996) were evaluated for both systems. Plant components were estimated (litterfall, pruning biomass, crop residues and grains). Hydric components were separated in total rain, throughfall, stem flow, leaching and runoff. Soil nutrient content and $\mathrm{N}$ volatilization were also measured. The nutrient budget was calculated by the difference between external input and output. Internal turnover was determinated for the hydric and plant components.

Nutrient losses in native vegetation were at $6,9 \mathrm{~kg} \mathrm{ha}^{-1} \mathrm{~N}, 1,5 \mathrm{~kg} \mathrm{ha}^{-1} \mathrm{P}$, $4,7 \mathrm{~kg} \mathrm{ha}^{-1} \mathrm{~K}, 28,4 \mathrm{~kg} \mathrm{ha}^{-1} \mathrm{Ca}$ and 4,9 $\mathrm{kg} \mathrm{ha}^{-1} \mathrm{Mg}$. Leaching was the most important mechanism, reaching 46 a $96 \%$ of total loss; runolf was the smaller process. In alley 
cropping, losses were of $28,3 \mathrm{~kg} \mathrm{ha}^{-1} \mathrm{~N}, 5,5 \mathrm{~kg} \mathrm{ha}^{-1} \mathrm{P}, 13,3 \mathrm{~kg} \mathrm{ha}^{-1} \mathrm{~K}, 36,2 \mathrm{~kg} \mathrm{ha}^{-1} \mathrm{Ca}$ and $6,1 \mathrm{~kg} \mathrm{ha}^{-1} \mathrm{Mg}$. Those values were larger than in cerrado, because nutrient removal by grains.

Nutrient turnover in plant-soil cycle in the cerrado, occurred mainly by litterfall, with $2176 \mathrm{~kg} \mathrm{ha}^{-1}$ year $^{-1}$ of dry matter (DM). This component had $27,8 \mathrm{~kg} \mathrm{ha}^{-1}$ of $\mathrm{N}, 7,2 \mathrm{~kg} \mathrm{ha}^{-1}$ of $\mathrm{K}$ and $3,7 \mathrm{~kg} \mathrm{ha}^{-1}$ of $\mathrm{Mg}$. Litterfall contributed with to $64 \%$ to $83 \%$ of the total of these nutrients. For $\mathrm{P}$ and $\mathrm{Ca}$, the larger return to the soil came from throughfall, with $3,0 \mathrm{~kg} \mathrm{ha}^{-1} \mathrm{P}$ and $14,9 \mathrm{~kg} \mathrm{ha}^{-1} \mathrm{Ca}$. In the alley cropping system, plant components were more important, yielding $11039 \mathrm{~kg}^{-1}$ of $1 \mathrm{M}$ per year. Of this amount, $4465 \mathrm{~kg} \mathrm{ha}^{-1}$ was composed of pruning biomass, $4176 \mathrm{~kg} \mathrm{ha}^{-1}$ of crop residues and $2398 \mathrm{~kg} \mathrm{ha}^{-1}$ of litterfall. As a result, nutrient turnover was 2,9 to 7,0 times that of the cerrado.

Consequently, ammual numien budget in cento was of $8,5 \mathrm{~kg} \mathrm{ha}{ }^{1} \mathrm{~N}$.

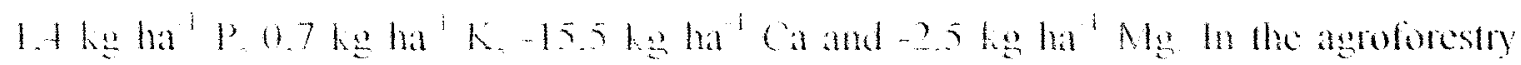

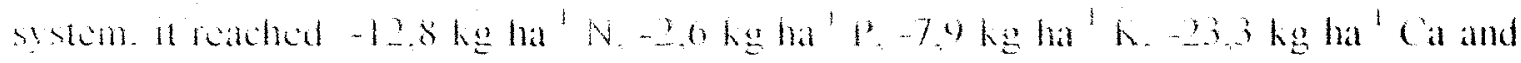
$-3.7 \mathrm{~kg}$ ha $\mathrm{Mg}$. The negative values reveal net loss of soil murients. This effect gradually exhausts soil firtility

The main benclits of alley cropping. as compared to cerrado, were increments in organic C, N, P, Ca and Mg to the soil surface layer $(0-20 \mathrm{~cm})$. This was the result of continuous nutrient turnover.

In spite of those gains in soil nutrients and organic matler, crop yields were low: $1210 \mathrm{~kg} \mathrm{ha}^{-1}$ of maize and $175 \mathrm{~kg} \mathrm{ha}^{-1}$ of beans. This is attributed to competition by leucaena and low soil nutrient levels, which, except for $\mathrm{N}$, were low to very low.

Thus, alley cropping can be recommended for production grain, without continuous fertilization. This will result in lowering external inputs for the farmer. Fertilization with $\mathrm{P}$ and $\mathrm{K}$ will, however, improve crop yields helping to equilibrate nutrient balance. 


\section{INTRODUCÃO}

O ecossistema de cerrado é responsável atualmente por cerca de $25 \%$ da produção brasileira de grãos, tendo como principal característica, a pobreza mineral dos solos. Para explorar adequadamente sua potencialidade agricola, tem se buscado alternativas de manejo viáveis para correção dessas limitações químicas, visando também a manutenção da matéria orgânica, com benefícios sobre a atividade biológica e os atributos lisicos do solo

Neste sentido. kn crescido a mberse por priticas como a

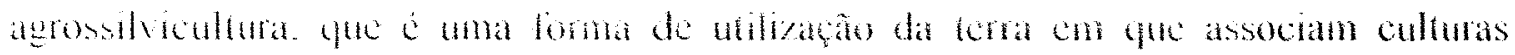

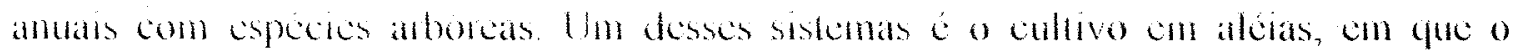
plantio infercalan é levo em laixas ente limhas de anvores listas plantas são periodicamente podadas adicionando litomassa ao solo. Essa prática intensilica a reciclagem de nutrientes e proporciona maior cobertura do solo, prolegendo-o contra a erosão. Como resultado, pode-se esperar uma cconomia no uso de lertilizante, além de manter a fertilidade do solo.

Este tipo de sistema agroflorestal é tradicionalmente empregado em regiões tropicais da África e Ásia, permitindo o cultivo continuo da terra, sem a degradação acelerada dos recursos naturais. No Brasil, os sistemas agroflorestais são novos, faltando estudos para otimizar as interações entre os componentes vegetais e o meio físico. Não se conhece qual a sua influência na ciclagem de nutrientes em condições de solos inférteis como os de cerrado.

O experimento teve como objetivo determinar o balanço de nutrientes (N, P, K, Ca e Mg) em um sistema agroflorestal do lipo cultivo em aléias e em uma área com vegetação nativa de cerrado, estimando-se as entradas e as saídas dos elementos 
minerais no sistema. Avaliou-se a influência do aporte de nutrientes a partir da litomassa das árvores na produção das culturas agrícolas, verilicando a possibilidade de reduzir a necessidade de insumos externos. Observou-se ainda, o efeito sobre os teores de nutrientes e matéria orgànica do solo, após 9 anos de manço, cm relação à condição original. 


\section{REVISĀO DE IITERATURA}

Nos ecossistemas naturais, as comunidades bióticas interagem com o meio, tendo seu desenvolvimento limitado pelas condições climáticas, pela disponibilidade de energia e de minerais. $O$ conhecimento da ciclagem dos nutrientes auxilia na compreensão do funcionamento dos ecossistemas e permite prever o efeito da ação antrópica sobre o sistema (Brown et al., 1994).

A ciclagem mineral pode ser caracterizada pelos componemtes

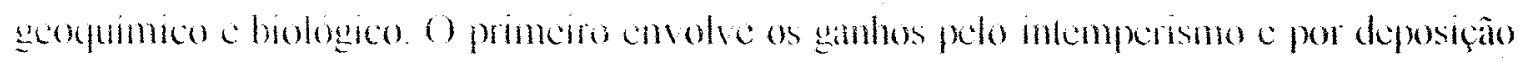

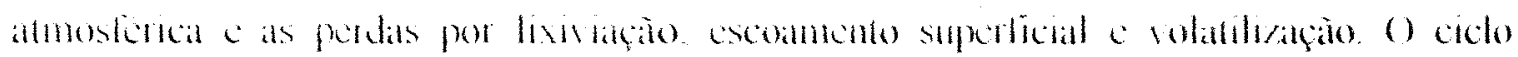

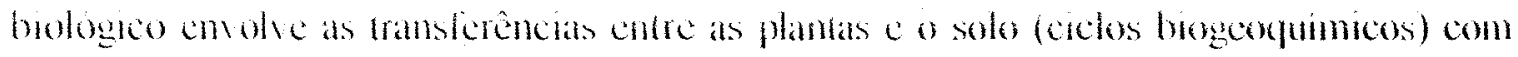
famhos atliares da decomposição da materia orgànica, da deposiçấo pola atividadé dos animais, pela lavagem da copa das árvores por ação da chuva e pelo uso de lertilizantes. As perdas se dão através da absorção pelos organismos, remoção pela colheita e através da queima. Dentro da planta, o metabolismo interno constitui um ciclo bioquímico (Landsberg, 1986).

A adoção de práticas agrícolas interfere em cada um desses ciclos, modilicando-os. A substituição da vegetação nativa por extensas monoculturas, sem levar em conta fatores ecológicos e sócio-econômicos, acarretou na degradação dos recursos naturais. Isso tem ocorrido nas últimas décadas, com a expansão da fronteira agrícola, especialmente no cerrado, onde os solos são ácidos, apresentam elevada saturação por alumínio e baixa reserva de nutrientes (Queiroz Neto, 1982).

A extrema simplificação dos agroecossistemas, tornou-os frágeis e sujeitos ao desenvolvimento incontrolado de pragas e doenças; o que levou ao uso intensivo de insumos de origem industrial, solicitando, portanto, alta demanda energética. $\mathrm{O}$ manejo 
inadequado do agroecossistema trouxe como consequência, a perda da capacidade produtiva do solo, além da contaminação ambiental.

Essa situação exige a busca de alternativas tecnoecológicas, que permitam o equilibrio entre a produção de alimentos e a conservação dos recursos naturais. Faz-se necessário a adaptação de agrossistemas com maior diversidade de espécies e maior estabilidade de produção, intensificando a reciclagem de nutrientes e minimizando perdas ao proteger o solo contra crosão. A redução da necessidade de insumos externos através da integração de dilerentes atividades na propriedade, com produtos diversos, pode minimizar os riscos, do ponto de vista econômico e ambiental.

No passado, grande parte das pesquisas desenvolvidas no cerrado buscaram superar a limitação mineral dos solos, porém, sem maximizar o aproveitamento dos fertilizantes e evitar a perda da matéria orgânica. Hoje, diversas práticas alternativas têm sido propostas, tais como adubação verde, cobertura morta, rotação e associação de culturas c plantio dirctor(cocdert. 1985)

Fisludos lom revelado que as formas de cullivo que associam espécies arbócals cou perence e cullunas agricolas fsistemas agroflorestais), colaboram na manutençào da capacidade produtiva dos solos, possibilitando o cultivo continuo das tertas (Lundgren \& Nair, 1985).

Um tipo de sistema agrollorestal praticado atualmente é o cultivo em aléias, que consiste no aproveitamento agrícola do espaço formado entre linhas implantadas (renques) com espécies arbustivas ou arbóreas. Estas plantas, geralmente leguminosas, são periodicamente podadas durante a época de cultivo. A fitomassa arbórea proveniente da poda é espalhada sobre o solo e a sua decomposição colabora no suprimento de nutrientes para as espécies anuais. O uso de leguminosas ajudaria, ainda, a aumentar o aporte de nitrogênio através da fixação simbiótica (Kang et al., 1981).

Essa prática de adubação verde tende a minimizar o uso de insumos provenientes de fora da propriedade, resultando em vantagem econômica, especialmente para agricultores descapitalizados. Além disso, a associação de diferentes espécies em uma mesma área proporcionaria, também, maior diversidade no ambiente assemelhando-se aos ecossistemas naturais. A maior biodiversidade diminuiria o risco de crescimento 
desordenado de organismos patogênicos ou pragas. Com o sistema agrollorestal obtem-se ainda, uma maior cobertura do solo, reduzindo perdas por erosão e o aparecimento de plantas invasoras (Lundgren \& Nair, 1985).

Embora freqüentemente descrito como sistema de produção de baixo consumo de insumos, o cultivo em aléias não é limitado a essas situações, sendo aplicável em condições de alta tecnologia, com lertilização mineral e irrigação (Ssekabembe, 1985).

O sucesso desse sistema depende, sobretudo, da escolha das espécies arbóreas, com preferência para as de crescimento rápido, com potencial de lixação de nitrogênio, rebrote vigoroso e adaptação às condições edaloclimáticas. A leucena (leucuena lencocephala), uma leguminosa arbustiva perene, originária do Peru, foi avaliada, sob cultivo em aléias, em Botucatu, SP (Bertalot et al., 1993). Mostrou resistência à seca, produção satisfatória de fitomassa, boa aceitação pelos bovinos e rebrote mesmo após priodos de lrio geadas leves.

No Brisil am dos primenos estudos con cultivo em alcias no cerrado,

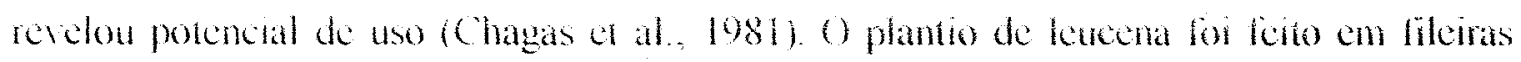
distantes ente si de 5 e $3 \mathrm{~m}$, entre as quais era cultivado o lejäo. A fitomassa dos arbustos atingiu 7 a 10 t ha ${ }^{1}$ de matéria seca Neste sistema, a cultura intercalar (feijão), recebendo apenas a adubação verde incorporada na faixa de cultivo, teve rendimento de $2220 \mathrm{~kg} \mathrm{ha}{ }^{-1}$, equivalente ao tratamento que recebeu adubação mineral.

Resultados como esses, têm motivado o estudo das interações ecológicas, atmosféricas e edálicas, entre as culluras e as espécies arbóreas e/ou arbustivas. Tais interações interlerem na dinâmica dos nutrientes no sistema, podendo ser manejadas, de forma a intensificar o aproveitamento pela culturas (Ong et al., 1991).

\subsection{Interações atmosféricas.}

Como interações atmosfëricas, devem ser considerados o sombreamento, a velocidade do vento, temperatura, umidade do ar e interceptação da chuva. Em um allissol na Nigéria, observou-se que o conteúdo de água na camada superficial do solo $(0-5 \mathrm{~cm})$ foi superior no cultivo em aléias, em relação ao monocultivo em solo arado ou com plantio direto. Isso se deveu ao aumento do 
sombreamento e ao efeito de quebra-vento dos renques, reduzindo a evaporação (Lal, 1989a).

A competição por água, luz e nutrientes, entre as árvores e as culturas, especialmente em clima seco, pode ocasionar redução no rendimento. Conludo, um efeito benéfico dessa interação pode manifestar-se na diminuição do crescimento das plantas daninhas, devido ao maior sombreamento (Singh et al., 1989).

Uma possível estratégia de manejo em sistemas agroflorestais, pode ser a combinação de plantas com diferentes ciclos fotossintéticos. Plantas C3 suportam melhor o sombreamento proporcionado pelos renques. As plantas $\mathrm{C} 4$, por outro lado, apresentam maior competição com as árvores (Ong et al., 1991).

A fileira de árvores pode funcionar como uma armadilha para a poeira, 0 que pode ser benéfico, principalmente quando o pó for mais rico em nutrientes que o solo original. Além disso, o cordão vegetal intercepta também, parte da chuva, redurindo a desagregaçăo a erosào. mantendo assim, a lentilidade do solo (Szoll et al, 1901a).

\subsection{Interaçós edalicas.}

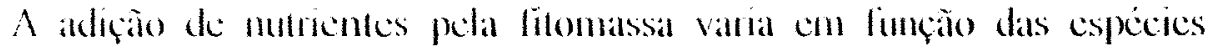
envolvidas e da proporçào relativa entre folhas e caule do material podado. Para uma mesma espécie, o "input" mineral depende da fertilidade do solo, clima, idade da planta e frequência de podas (Palm, 1995). No caso da leucena, a adição de nutrientes pela litomassa a cada poda pode variar de 20 a $100 \mathrm{~kg} \mathrm{ha}^{-1}$ de N, 2 a $5 \mathrm{~kg} \mathrm{ha}^{-1}$ de $\mathrm{P}, 10$ a $90 \mathrm{~kg} \mathrm{ha}^{-1}$ de $\mathrm{K}, 1$ a $10 \mathrm{~kg} \mathrm{ha}^{-1}$ de Mg e 2 a $25 \mathrm{~kg} \mathrm{ha}^{-1}$ de Ca (Fernandes et al., 1993).

Além do aporte de minerais, os sistemas agrollorestais podem fornecer ao solo 3 a $15 \mathrm{t} \mathrm{ha}^{-1}$ ano $^{-1}$ de carbono, com um adicional de 1,3 a $6,5 \mathrm{t} \mathrm{ha}^{-1}$ ano $^{-1}$ de $\mathrm{C}$ através das raizes (Sanchez, 1995).

A presença de raizes profindas das árvores dos sistemas agroflorestais, minimiza a perda de nutrientes por lixiviação, em comparação ao monocultivo. A associação de espécies pode melhorar o enraizamento das plantas anuais, a partir da atividade das minhocas e das raizes mortas, criando canais. Além disso, a liberação dos 
exsudatos radiculares e dos compostos orgânicos durante a decomposição dos tecidos mortos, auxilia na redução da toxidę de alumínio em subsuperlicie (Schroth, 1995).

A dinâmica do nitrogênio também tem sido objeto de investigação em sistemas agroflorestais. A fixação biológica aparece como um dos principais efeitos benéficos das espécies arbóreas. No caso da leucena em cultivo em aléias, num solo aluvial e pobre em nutrientes da Tanzânia, a fixação biológica foi de $110 \mathrm{~kg} \mathrm{ha}^{-1}$ ano-1 de nitrogênio (Högberg e Kuarnström, 1982).

Desse total, porém, somente uma parte é aproveitada pelas culturas. Estudos com uso do isótopo ${ }^{15} \mathrm{~N}$, mostraram que a absorção do $\mathrm{N}$ pelo milho, cultivado após a incorporação da fitomassa, foi de apenas $9 \%$ do total aos 90 dias após a semeadura (Xu et al., 1993). Essa baixa disponibilidade estava relacionada ao alto teor de polifenóis, que atrasaram a decomposição microbiana. Outro trabalho, com milho, revelou que o aproveitamento do nitrogêno proveniente da leucena, variou de $28 \%$ no primciro cultivo ate $70^{\circ}$ " hos cultivos subsequentes (llaggat et al, 1903). A fraça restante licou imobilizada pelos microrganismos do solo, cm moléculas orgânicas, ou então, foi perdida.

Com mancjo adequado do solo (plantio em nível, manutenção dos restos cullurais sobre o solo, não realização da queima), as perdas de $N$ no sistema, são inleriores a $20 \%$ (Palm, 1995). Os processos de perda são a denitrilicação, o escoamento superlicial e a lixiviação.

Com relação ao lósforo, elemento mais limitante na produção vegelal em solos tropicais, observou-se uma absorção até $60 \%$ maior, pelas culturas nas aléias, com adição do material podado, em comparação às parcelas onde a litomassa foi removida (Haggar et al., 1991). Isto foi atribuido à maior capacidade de absorção da leucena, pelo sistema radicular profundo, perene e possivelmente com sistema micorrizico mais eficiente. Outro efeito sugerido foi advindo do aumento da matéria orgânica na camada superficial do solo, diminuindo a fixação do $\mathrm{P}$ pelos minerais e aumentando a disponibilidade a partir de formas orgânicas.

Sob cultivo em aléias, os nutrientes catiônicos ( $\mathrm{Ca}, \mathrm{Mg} \mathrm{e} K$ ) normalmente acumulam-se na camada superficial. A razão apontada é a reciclagem dos cátions a partir de camadas mais prolundas do solo e a consequente liberação através da 
decomposição das raízes, serapilheira e residuos culturais. Quandó é feita a remoção contínua da litomassa sobre o solo ou, ainda, cuando ocorre erosão, pode haver diminuição dos teores destes elementos no solo (Lal, 1989b)

Além do fornecimento de nutrientes, a adição de litomassa intervém favoravelmente sobre outras propriedades do solo. O cultivo em aléias durante cinco anos num alfissol, em Ibadan, Nigéria, aumentou a capacidade de troca catiônica (CTC), na camada de $0-10 \mathrm{~cm}$ de profundidade, quando comparado ao monocultivo (Lal, 1989c). Este aumento esteve relacionado à variação no teor de carbono orgânico.

A conservação da matéria orgânica é um dos aspectos mais importantes na manutenção da capacidade produtiva dos solos, especialmente nas condições de cerrado. Entre os principais benefícios estão a maior disponibilidade de nutrientes e melhoria das propriedades físicas e biológicas do solo (Pereira \& Peres, 1985). Outro efeito observado é a complexaçâo do aluminio, pelos ácidos orgânicos c polissacarideos liberados durante a decomposição dos residuos (Szoll et al , 1991a).

Com relação as propricdades lisicas do solo, observoti-se que o cultivo em aleias em um oxissol, aumentou o diânetro médio dos agregados, em comparação ao monocultivo (Yamoah et al, 1986). Notou-se também a diminuição da densidade do solo e o aumento da capacidade de armazenamento de água, devido ao aporte de matéria orgânica. A conservação da água no solo também é favorecida pela cobertura, que minimiza a evaporação (Ingram, 1990). Tais efeitos podem, provavelmente, reduzir a erodibilidade do solo.

As alterações provocadas pelo manejo do solo sobre os atributos biológicos têm sido relacionados, cada vez mais, à disponibilidade de nutrientes. Num experimento com aplicação da fítomassa podada, notou-se aumento da atividade microbiana; com a duplicação da mineralização de $\mathrm{N}$ em comparação ao monocultivo (Haggar et al., 1993).

Em termos de potencial produtivo, o sistema de cultivo em aléias tem dado resultados animadores. Em um experimento de maior duração, conduzido num alfíssol no Zaire, verificou-se que o rendimento de milho associado à leucena plantada em aléias, foi de até $2000 \mathrm{~kg} \mathrm{ha}^{-1}$, mesmo sem fertilizantes. Tal sistema substituiu com vantagem o 
sistema de cultivo solteiro com fertilizantes, embora as respostas em rendimento, somente ocorreram a partir do 5 ano. Nolou-se também menor llutuação de produção, principalmente nos anos mais desfavoráveis ao crescimento da cultura (Shannon et al, 1994). Sabe-se, porém, que esses resultados são variáveis conforme as condições edafoclimáticas e de manejo adotadas.

Assim sendo, os sistemas agroflorestais apresentam grande potencial para produzir alimentos, além de manter a fertilidade de solos ácidos e inférteis. A eficiência de tais práticas, em termos de ciclagem de nutrientes, tem sido estudada parcialmente, dando-se pouca ênfase às propriedades do solo (Sanchez, 1995). De maneira geral, poucos são os trabalhos que comparam a dinâmica dos elementos minerais em sistemas agrícolas e em ecossistemas naturais. 


\section{MATERIAL E MÉTODOS}

\subsection{Caracterização da área experimental.}

$\mathrm{O}$ experimento localiza-se em Botucatu, SP $\left(22^{\circ} 57^{\prime} \mathrm{S}, 48^{\circ} 25^{\prime} \mathrm{O}\right.$, altitude de $900 \mathrm{~m}$ ). O solo corresponde um Latossolo Vermelho Amarelo distrófico, A moderado, textura média, ácido, derivado de arenito do Grupo Bauru (Instituto de Pesquisas Tecnológicas, 1981). A vegetação natural da área era de cerrado.

O clima é do tipo Cfa: mesotérmico úmido com verão quente, segundo a classificação de Köeppen. A temperatura média anual é de $20{ }^{\circ} \mathrm{C}$ e a pluviosidade média é de $1350 \mathrm{~mm} \mathrm{ano}^{-1}$. A estação seca se desenvolve de junho a agosto (Setzer, 1966). A temperatura média minima anual é de $15,8^{\circ} \mathrm{C}$ e a média máxima anual é de 25,1 "C. A umidade relativa do ar média anual é de $75 \%$ (Nascimento \& Pereira).

\subsection{Manejo das culturas e do solo.}

A espécie arbórea foi a leucena (Leucaena leucocephala var. Peru), plantada em 1987, com espaçamento de $6 \mathrm{~m}$ entre renques e $0,4 \mathrm{~m}$ entre plantas. Não foi feita inoculação das sementes. O manejo da leucena consistiu na poda anual a $60 \mathrm{~cm}$ de altura do solo, realizada antes da semeadura da cultura de verão. Na safra 93/94 não se podou em função da ocorrência de geada, sendo a fitomassa obtida em 1995 equivalente a 24 meses de crescimento vegetativo. Esses ramos e folhas foram distribuidos sobre o solo, nas faixas de cultivo.

As espécies anuais nas faixas de cultivo eram plantadas no inverno e verão, consorciando-se gramíneas e leguminosas (Tabela 1). Em maio de 1995 iniciouse o periodo de avaliação, com a incorporação da fitomassa de milho consorciado com mucuna preta (Mucuna aterrima) e lablab (Dolichos lablab). Seguiu-se, durante o inverno, com centeio (Secale cereale) e aveia (Avena sativa) consorciados, semeados a 
lanço, em 23/05/1995. A fitomassa foi incorporada ao solo como adubo verde em 10/10/1995. As culturas de verão foram o milho e o feijão adzuki (Vigna umbellata) consorciados, semeados em linhas, em 11/10/1995. Cada faixa tinha 5 linhas de milho, com 35.000 plantas ha $^{-1}$ e 4 linhas de feijão, com 150.000 plantas ha ${ }^{-1}$. As sementes utilizadas foram de variedades locais.

Tabela 1. Sequência de cultivos anuais nas faixas entre os renques.

\begin{tabular}{lcc}
\hline CULTURAS & SEMEADURA & COLHEITA \\
\hline Centeio, aveia, ervilhaca & mar/abr. 1988 a 1994 & set/out. 1988 a 1994 \\
Milho, soja, feijão, mucuna preta & set/out. 1987 a 1993 & mar/abr. 1988 a 1994 \\
Milho + mucuna preta + lablab & out. 1994 & $20 /$ maio/1995 \\
Centeio + aveia & $23 /$ maio/1995 & $08 /$ out./1995 \\
Milho + feijão adzuki & $10 /$ out./1995 & 25/jan./1996 (Feijão) \\
& & $29 /$ abr./1996 (Milho)
\end{tabular}

Observação: em destaque o periodo de condução do experimento.

O solo foi corrigido por ocasião do plantio da leucena, com calcário dolomítico $\left(2400 \mathrm{~kg} \mathrm{ha}^{-1}\right)$ e com termofosfato $\left(20 \mathrm{~kg} \mathrm{ha}^{-1} \mathrm{de} \mathrm{P}\right)$. O preparo do solo empregado era a roçada da cultura anterior, seguida de gradagem. Não foi realizada adubação mineral de manutenção nas culturas.

\subsection{Delineamento experimental.}

O delineamento foi inteiramente casualizado, com dois tratamentos (sistema agroflorestal e cerrado) e dez repetições. $\mathrm{Na}$ área de cerrado foi delimitada uma área de $30 \times 30 \mathrm{~m}$. No sistema agroflorestal foram estudadas duas faixas de cultivo, tendo cada uma $22 \times 8 \mathrm{~m}$ (Figura 1).

\subsection{Avaliaçóes.}

Estimou-se a densidade de plantas de leucena e a composição florística no cerrado em 4 parcelas de $10 \times 10 \mathrm{~m}$. Separou-se as plantas em classes de 
altura, em arbustos pequenos (até $1 \mathrm{~m}$ ), arbustos de 1 a $3 \mathrm{~m}$ e arvoretas (mais de $3 \mathrm{~m}$ ). A vegetação rasteira foi quantificada em quatro parcelas de $3 \times 3 \mathrm{~m}$, contando-se o número de plantas e separou-se os indivíduos da família Gramineae.

$\uparrow$ Norte
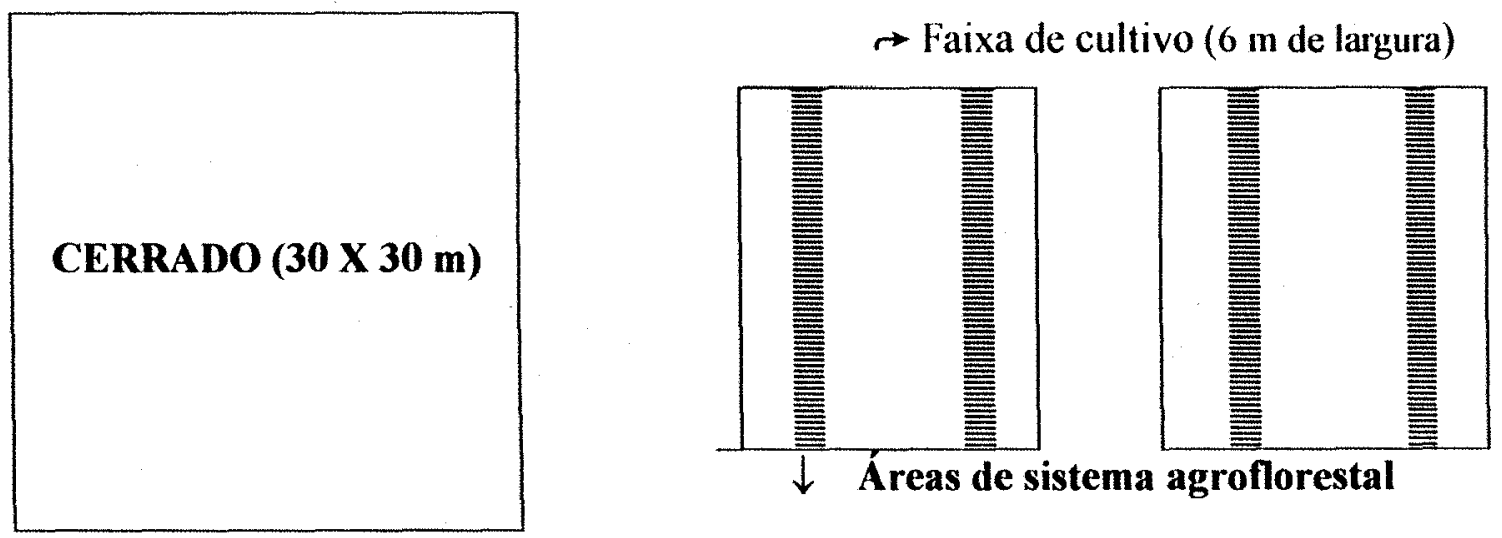

Renques de leucena $\quad(22 \times 8 \mathrm{~m}$, cada $)$

Figura 1. Distribuição das parcelas no campo.

Fez-se a descrição morfológica dos solos, avaliando a cor, estrutura, distribuição de raizes, textura, porosidade e consistência dos horizontes (Lemos \& Santos, 1976). Coletou-se amostras nas profundidades de $0-5 ; 5-10 ; 10-20 ; 20-40 ; 100-$ 110 e 150-160 cm, para análise granulométrica pelo método do densímetro (Empresa Brasiliera de Pesquisa Agropecuária, 1979). As análises químicas seguiram a metodologia descrita por Raij \& Quaggio, (1983). O teor de $\mathrm{N}$ total foi analisado pelo método de Kjeldahl; o $\mathrm{P}$ foi extraído por resina e determinado por colorimetria; o $\mathrm{K}, \mathrm{Ca}$ e $\mathrm{Mg}$ foram extraídos por resina e determinados por espectrofotometria de absorção atômica e o $\mathrm{C}$ orgânico foi analisado pelo método de Walkley-Black. Foram analisados ainda, o pH em solução salina $\left(\mathrm{CaCl}_{2} 0,01 \mathrm{M}\right)$ e a acidez potencial, extraída por solução SMP. Calculou-se a soma de bases, a capacidade de troca de cátions e a saturação por bases $(\mathrm{V} \%)$.

Para estimativa do balanço de nutrientes (N, P, K, Ca e $\mathrm{Mg}$ ) foram distinguidos os componentes hídricos, vegetais e edáficos (Langkamp et al., 1982). $O$ 
periodo de coleta foi de junho de 1995 a maio de 1996, separando-se em estação seca, com o cultivo de inverno (jun./1995 a out./1995) e estação chuvosa, com o cultivo de verão (nov./1995 a maio/1996).

\subsubsection{Componentes hídricos.}

Os componentes hídricos avaliados foram a precipitação incidente, 0 gotejamento de copa, o fluxo de caule, a enxurrada e a lixiviação.

A precipitação incidente foi o mecanismo de entrada de nutrientes externo ao sistema (ciclo geoquímico), sendo considerada a chuva livre, fora da área de ação da copa das plantas. O gotejamento de copa e o fluxo de caule foram os componentes responsáveis pela reciclagem interna do sistema (ciclo biogeoquímico), coletados sob a copa das plantas. São formados a partir da chuva livre, que solubiliza nutrientes na vegetação e os devolve ao solo, juntamente com o processo de lavagem da pocira captada na copa das plantas. Essa divisão permile identilicar a participação da vegetação na interceptação da chuva, que é fração retida na copa das plantas. A parte restante (líquida) consiste na chuva que atinge o solo (Painter, 1976). O cálculo baseiase nas seguintes relações:

Interceptação $=$ Precipitação incidente $-($ Gotejamento da copa + Fluxo de caule) .

Precipitação líquida $=$ Gotejamento da copa + Fluxo de caule.

A enxurrada e a lixiviação foram os mecanismos de perda de nutrientes do sistema (ciclo geoquímico). A enxurrada corresponde à ação da erosão, arrastando nutrientes nos sedimentos e solúveis, pelo escoamento superficial. Na lixiviação, os nutrientes são levados em solução, com o movimento de percolação.

Esses componentes hidricos foram medidos semanalmente, coletandose alíquotas proporcionais ao volume total, conservadas sob refrigeração e acidificadas até pH 2,0 ( $\left(\mathrm{H}_{2} \mathrm{SO}_{4}\right)$. Efetuou-se análise ao final de cada estação para $\mathrm{N}, \mathrm{P}, \mathrm{K}, \mathrm{Ca}$ e $\mathrm{Mg}$, de acordo com Tedesco et al., (1985). Calculou-se a altura da lâmina de água coletada, em mm. A concentração média anual foi calculada pela média ponderada das concentrações em cada safra, considerando a altura coletada em cada periodo. As quantidades de nutrientes foram agrupadas a cada mês. 
a) Precipitação incidente.

Consistiu na chuva livre, sem interceptação. Foi obtida em dois pluviômetros de $\mathrm{PVC}$, de $8,0 \mathrm{~cm}$ de diâmetro, instalados a $80 \mathrm{~cm}$ de altura do solo, sem a cobertura das árvores. Representou a contribuição de nutrientes a partir da atmosfera.

b) Gotejamento de copa.

Compreende a fração da precipitação livre (incidente) que atinge a copa das plantas e respinga 'posteriormente para o solo. Neste processo a solução é enriquecida por nutrientes solúveis do tecido vegetal e presentes nas partículas sólidas sobre as folhas. O gotejamento de copa foi cotetado em 10 pluviômetros de PVC com $8,0 \mathrm{~cm}$ de diâmetro, instalados de forma sistemática no cultivo em aléias, em dois alinhamentos transversais ao renques. Assim, foi possível coletar a fração da chuva que era interceptada pela leucena e posteriormente respingava para o solo. No cerrado foram dispostos 10 pluviômetros, aleatoriamente a uma altura de $80 \mathrm{~cm}$ do solo. A chuva foi armazenada em recipiente plástico de $1 \mathrm{~L}$ (Figura 2a), com tela para impedir a entrada de insetos e folhas.

Os valores (alturas) do gotejamento da copa que foram superiores à precipitação livre foram substituídos pela média desta, nos cálculos. Isto ocorre quando há maior concentração de gotas em alguns pontos, devido ao efeito do vento e à cobertura foliar sobre o coletor, cuja área de coleta é pequena $\left(50,3 \mathrm{~cm}^{2}\right)$.

c) Fluxo de caule.

Considera-se o fluxo de caule como a porção da precipitação livre que chega à copa da planta e desce para o solo pelo caule. Foram postos anéis de plástico, convergindo a solução para recipientes de $5 \mathrm{~L}$ (Figura 2 b). Foi medido em 10 plantas de cada tratamento.

Salienta-se que a adição de nutrientes pelo fluxo de caule e gotejamento de copa, foi calculada, descontando-se o teor médio presente na precipitação incidente.

d) Enxurrada.

Delimitou-se uma parcela de $3,5 \times 5,0 \mathrm{~m}$ por tratamento. A maior dimensão foi disposta no sentido do declive (Figura 2c). A declividade média era de 11 
\%. Determinou-se as perdas de solo, água e nutrientes por escoamento superficial, acumulados nas caixas coletoras (Figura $2 \mathrm{~d}$ ).

e) Lixiviação.

Como lixiviação considerou-se o volume de solução percolado no solo até uma profundidade de 1,6 m. Em cada tratamento usou-se um lisímetro de drenagem.

Os lisimetros tinham $0,8 \mathrm{~m}$ de diâmetro e $1,6 \mathrm{~m}$ de profundidade. No fundo havia uma camada de $10 \mathrm{~cm}$ de brita $(2$ a $3 \mathrm{~cm}$ de diâmetro) e $5 \mathrm{~cm}$ de areia grossa, para facilitar a drenagem até o recipiente armazenador (Figura 3a). Os cilindros foram construidos em chapa galvanizada, revestida com tinta betuminosa. No sistema agroflorestal foi feito a semeadura das culturas na superfície do lisímetro e no cerrado deixou-se as ervas crescerem, simulando a condição local de cobertura do solo.

\subsubsection{Componentes vegetais.}

Os componentes vegetais avaliados foram a serapilheira, a fitomassa da poda da leucena e a produção das culturas (matéria seca da parte aérea e grãos colhidos). Com exceção dos grãos, esses componentes contribuem com a reciclagem de nutrientes da planta ao solo (ciclo biogeoquímico). Os grãos foram um mecanismo de perda de nutrientes no sistema agroflorestal.

A fitomassa dos componentes vegetais foi determinada após secagem em estufa à $65^{\circ} \mathrm{C}$, até peso constante. Em subamostras de tecido vegetal digerido foram analisados o $\mathrm{N}$ total, pelo método semi-micro Kjeldahl, o $\mathrm{P}$ por colorimetria e o K, Ca e Mg por espectrofotometria de absorção atômica (Malavolta et al., 1989).

a) Serapilheira.

Constitui nos fragmentos vegetais caídos sobre o solo, coletados em 10 bandejas de $0,5 \mathrm{~m}^{2}$, com tela plástica de $1,0 \mathrm{~mm}$ no fundo (Figura $3 \mathrm{~b}$ ), dispostas a $50 \mathrm{~cm}$ de altura do solo, de forma sistemática, em alinhamentos transversais aos renques. Assim, foi possivel avaliar o gradiente de produção conforme a distância da leucena. No cerrado foram distribuídas 10 bandejas de forma aleatória. A coleta do material foi quinzenal. 

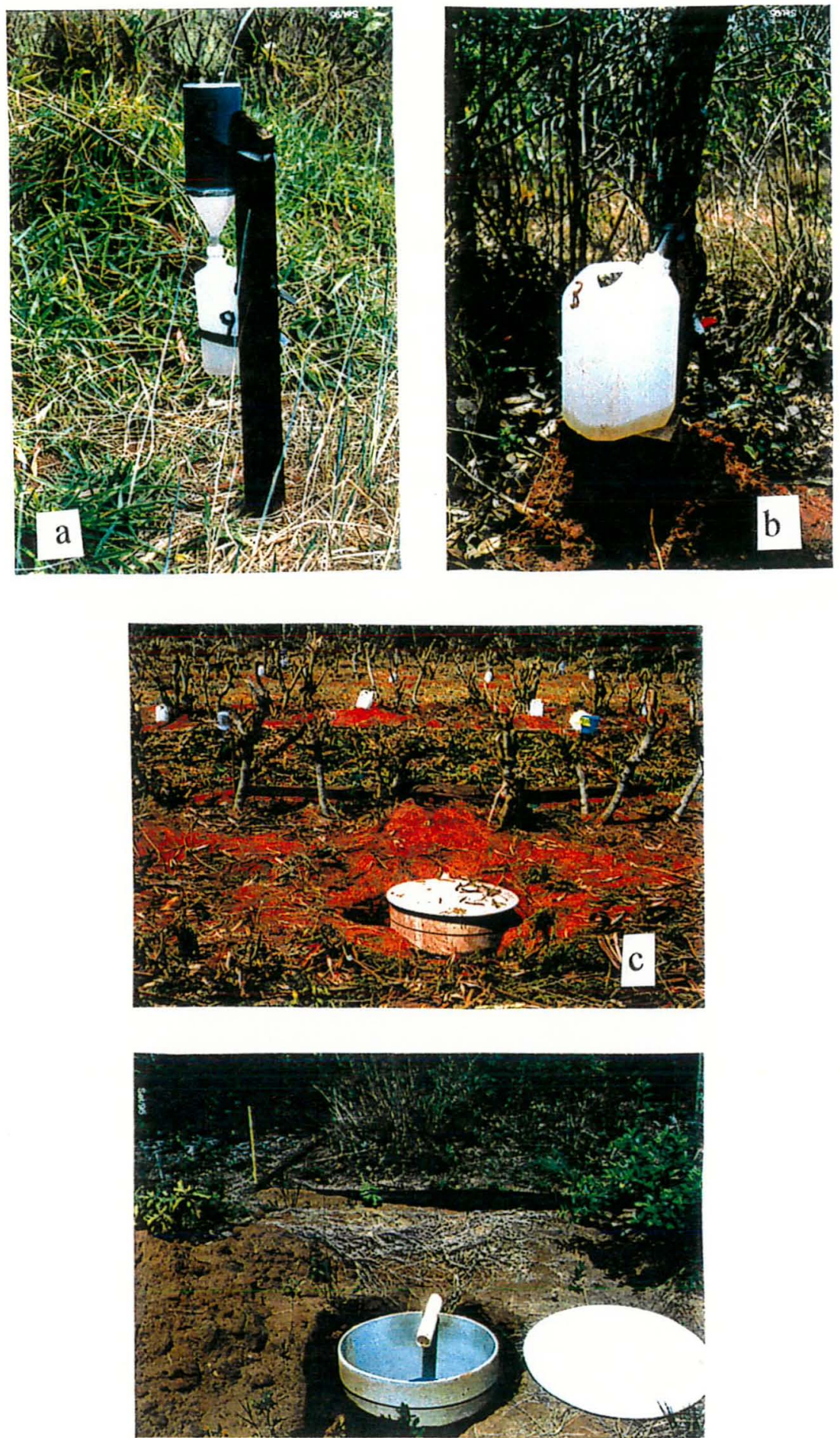

Figura 2. Pluviômetro (a); Coletor de fluxo de caule (b); Parcela coletora de enxurrada (c); Caixa coletora de enxurrada (d). 
b) Fitomassa da poda.

A fitomassa proveniente da poda da leucena foi amostrada em 10 plantas, escolhidas ao acaso. O material foi separado em folhas e ramos (com diâmetro superior a $0,5 \mathrm{~cm}$ ).

c) Produção das culturas.

Quantificou-se os grãos e os resíduos da parte aérea em 16 amostras de $1,0 \mathrm{~m}^{2}$, coletadas de forma sistemática, conforme a distância dos renques.

\subsubsection{Componentes edáficos.}

Foi avaliada a reserva de nutrientes do solo na camada de 0-160 $\mathrm{cm}$ de profundidade e a perda de nitrogênio por volatilização na forma de amônia.

a) Nutrientes no solo.

$\mathrm{O}$ teor de nutrientes no solo foi determinado em duas amostras compostas ( 25 subamostras), na profundidade de $0-20 \mathrm{~cm}$., coletadas a cada 3 meses, totalizando 10 amostras por tratamento. Na profundidade de 20 a $160 \mathrm{~cm}$ utilizou-se os dados obtidos na descrição dos solos nas trincheiras. Analisou-se os teores de C orgânico, N, P, K, Ca e Mg, conforme metodologia de Raij \& Quaggio (1983).

b) Volatilização de nitrogênio.

Foram instalados cinco coletores semi-abertos estáticos, por tratamento (Figura 3c). Os cilindros de PVC transparente, continham espumas, embebidas em solução de ácido sulfúrico $\left(15 \mathrm{ml} \mathrm{L}^{-1}\right)$ e glicerina $\left(30 \mathrm{ml} \mathrm{L}^{-1}\right)$. As amostragens eram feitas a cada 12 dias, de outubro de 1995 (poda da leucena) até março de 1996, num total de 11 coletas. A amônia retida na espuma foi extraída com água destilada, posteriormente destilada e determinada por titulometria (Lara Cabezas \& Trivelin, 1990).

\subsubsection{Estimativa do balanço de nutrientes.}

Estimou-se as perdas e ganhos anuais de nutrientes $\left(\mathrm{kg} \mathrm{ha}^{-1}\right)$, obtendose o saldo (entradas - saídas). Calculou-se a reciclagem de nutrientes entre a planta e solo, estimando assim a disponibilidade para as plantas. 

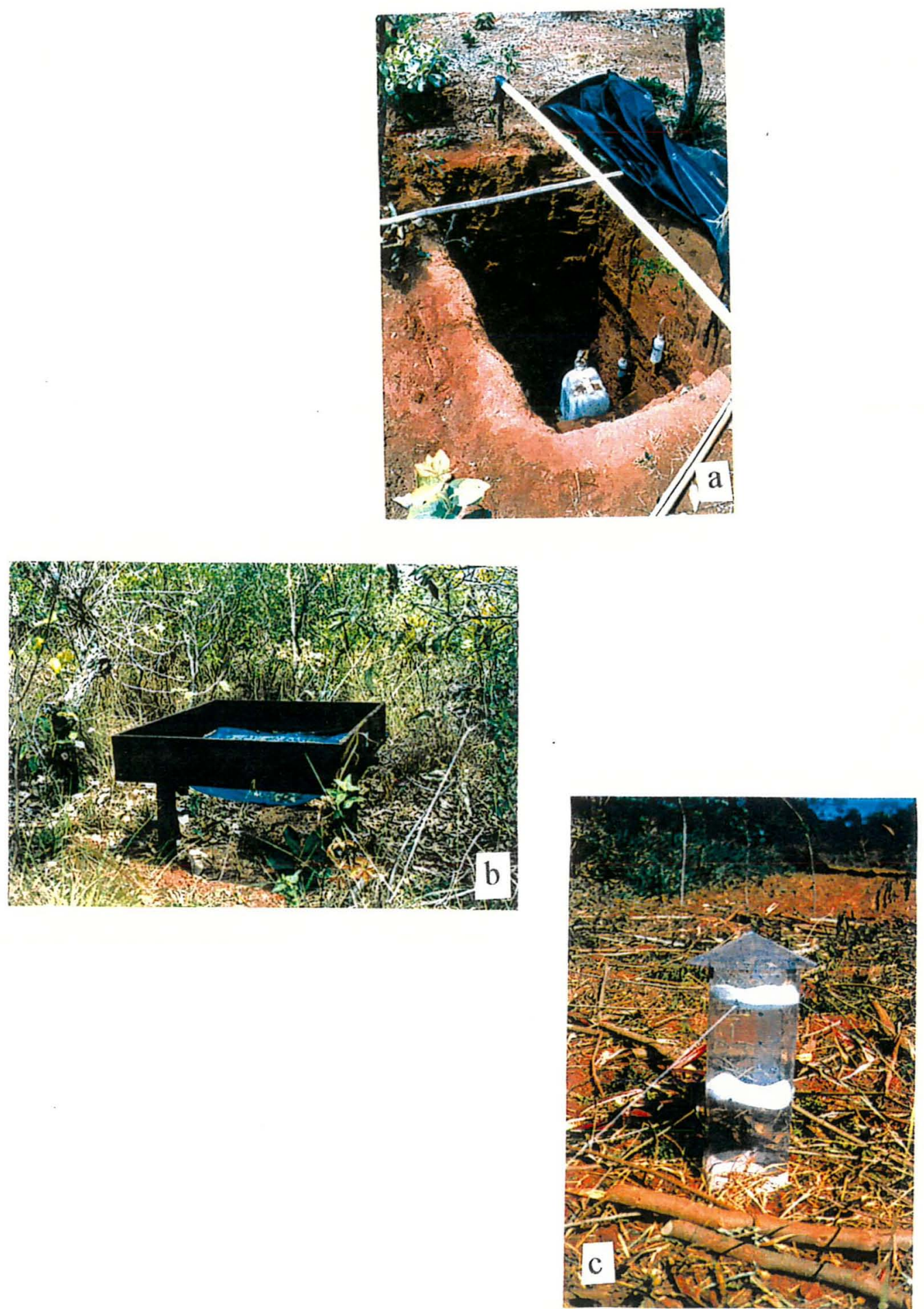

Figura 3. Coletores de lixiviação (a); Bandeja coletora de serapilheira (b); Coletor de volatilização de nitrogênio (c). 
a) Área de cerrado: os componentes considerados foram:

- Entrada = precipitação incidente;

- Ciclo planta-solo = gotejamento de copa + fluxo de caule + serapilheira;

- Saidas = enxurrada + lixiviação.

b) Área do cultivo em aléias:

- Entrada = precipitação incidente;

- Ciclo planta-solo $=$ gotejamento de copa + fluxo de caule + serapilheira + fitomassa podada + resíduos da parte aérea;

- Saídas = enxurrada + lixiviação + volatilização de $\mathrm{N}+$ remoção pela colheita .

\subsection{Análise dos resultados.}

A remoção de nutrientes nos grãos, a fitomassa e a adição de nutrientes pela poda da leucena e pelas culturas no sistema agroflorestal foram descritas pela média \pm intervalo de confiança de $95 \%$, calculado pelo teste $t$.

O fluxo de caule, a lixiviação, a enxurrada, a volatilização de amônia, o teor de nutrientes no solo (camada de $0-20 \mathrm{~cm}$ ) e a produção de feijão na linha central e lateral da faixa de cultivo, foram submetidos à análise da variância pelo teste $F$, com $5 \%$ de significância (Tabela 2 ).

A produção média de serapilheira e os nutrientes na precipitação e lavagem de copa em cada transecto (conjunto de 3 coletores: junto ao renque, em posição intermediária e no centro da faixa de cultivo) foram comparados com os valores do cerrado. Aplicou-se o teste $\mathrm{t}$ para dados não emparelhados, com variâncias populacionais desconhecidas e supostamente distintas, com $5 \%$ de significância.

Calculou-se a correlação entre a chuva e o gotejamento de copa, fluxo de caule e interceptação. Verificou-se também a correlação para o fluxo de caule e o diâmetro e altura das plantas. Nos casos onde o coeficiente de correlação foi significativo, realizou-se a análise de regressão. Esta também foi empregada para a produção de serapilheira da leucena e para o rendimento de grãos do milho, conforme a distância dos renques. 
Tabela 2. Esquema de análise da variância.

\begin{tabular}{llc}
\hline ATRIBUTO ANALISADO & CAUSA DE VARIAÇÃO & GRAUS LIBERDADE \\
\hline Fluxo de caule & Local & 1 \\
& Resíduo & 18 \\
& Total & 19 \\
\hline Lixiviação e enxurrada & Local & 1 \\
& Época & 7 \\
& Resíduo & 7 \\
& Total & 15 \\
\hline Volatilização de amônia & Local & 1 \\
& Resíduo A & 8 \\
& Parcelas & 9 \\
& Épocas & 10 \\
& Local * Época & 10 \\
& Resíduo B & 80 \\
& Total & 109 \\
\hline Nutrientes no solo & Local & 1 \\
& Época & 3 \\
& Local*Época & 3 \\
& Resíduo & 8 \\
& Total & 15 \\
\hline Produção nas linhas de feijãoo & Linha & 1 \\
& Resíduo & 14 \\
& Total & 15 \\
\hline
\end{tabular}

A volatilização de amônia foi corrigida conforme a eficiência dos coletores (Lara Cabezas \& Trivelin, 1990). A perda média no sistema agroflorestal a cada época, foi descontada dos valores obtidos no cerrado, eliminando a contribuição do nitrogênio liberado pela decomposição das espumas absorvedoras, obtendo-se a volatilização líquida proveniente da fitomassa podada da leucena. Posteriormente, fezse a análise de regressão para a perda total de nitrogênio acumulada a cada coleta. 


\section{RESULTADOS E DISCUSSÃO}

A apresentação inicia com a descrição das áreas trabalhadas, quanto a vegetação e solo. Posteriormente, são detalhadas separadamente as entradas e saidas de nutrientes em cada sistema, resultando no balanço.

\subsection{Composição florística.}

No sistema agroflorestal, a leucena tinha densidade de 3833 plantas $\mathrm{ha}^{-1}$, com espaçamento médio de $42 \mathrm{~cm}$ entre plantas no renque. Além do número de plantas, o aporte de nutrientes depende da produção individual de fitomassa. Verificouse que as plantas tinham diâmetro médio de caule $(60 \mathrm{~cm}$ de altura) de $5,5 \mathrm{~cm}$ e a altura variava de 3,0 a 4,0 m, com sistema radicular profundo (+ de $2 \mathrm{~m}$ ).

A vegetação do cerrado mostrou-se heterogênea em termos de espécies, com maior abundância de indivíduos das familias Asteraceae, Mirtaceae, Fabaceae e Araliaceae. Havia vegetação rasteira fechada, composta por gramíneas e outras ervas.

A diversidade de espécies é uma característica marcante desse tipo de vegetação, comprovada numa avaliação fitossociológica detalhada de um cerrado da região de Botucatu, SP. Descreveu-se 54 espécies vegetais entre árvores e arbustos. Na classe de árvores foram consideradas as plantas com mais de $3 \mathrm{~m}$ de altura, totalizando 1179 indivíduos por hectare. Os arbustos com menos de $3 \mathrm{~m}$ de altura e mais de $10 \mathrm{~cm}$ de circunferência de caule, medidos a $30 \mathrm{~cm}$ de altura do solo, totalizaram 3018 plantas por hectare (Gottsberger \& Eiten, 1983).

O porte das plantas caracterizou-se pela predominância de arbustos pequenos (Tabela 3). Notou-se ainda, abundância de vegetação rasteira e de serapilheira 
sobre o solo. Essa cobertura vegetal protege o solo do impacto da chuva, diminuindo a erosão. Além disso, sua decomposição pemite a manutenção de uma camada superficial de solo mais rica em nutrientes.

Tabela 3. População dos diferentes estratos de plantas no cerrado.

\begin{tabular}{lcc}
\hline Estratos de plantas & Altura $(\mathrm{m})$ & Número $^{-\mathrm{ha}^{-}}$ \\
\hline Arvoretas & $>3$ & 500 \\
Arbustos & $1 \mathrm{a} 3$ & 767 \\
Arbustos pequenos & $<1$ & 6467 \\
Gramíneas & -- & 49722 \\
Outras ervas & -- & 84167 \\
\hline
\end{tabular}

No solo, verificou-se a presença de sistema radicular profundo, atingindo mais de $2,5 \mathrm{~m}$ de profundidade. As raizes eram espessas, contribuindo para reserva de água e nutrientes. Nesse tipo de vegetação, as raizes representam importante proporção da fitomassa total da planta. A avaliação em um campo cerrado em Pirassununga, SP, indicou que o material vegetal sob o solo, nos primeiros $36 \mathrm{~cm}$ de profundidade, equivalia a massa presente no extrato subarbustivo-herbáceo acima do solo (Delitti et al., 1986). A fitomassa seca das raizes quantificada no campo cerrado em Mogi-Guaçú, SP, atingiu $12400 \mathrm{~kg} \mathrm{ha}^{-1}$ (Pompéia, 1989).

\subsection{Atributos morfológicos e físico-químicos dos solos.}

Os perfis de solo dos dois tratamentos (sistema agroflorestal e cerrado) eram semelhantes morfologicamente (Tabela 4).

Os solos apresentaram cores bruno avermelhado escura e vermelho amarela, textura média, estrutura fraca a moderada em blocos subangulares em superfície e forte muito pequena (microagregados) em profundidade. A consistência do solo quando seco, nos horizontes superficiais era dura a ligeiramente dura no sistema agroflorestal e ligeiramente dura a macia no cerrado. Em profundidade, era macia em ambos os perfis. A porosidade, tubular e intergranular, era forte. As raízes eram 
abundantes em superficie, muitas em subsuperficie e comuns em profundidade. Tais solos, apresentaram atração magnética muito fraca ou ausente. Podem ser classificados como Latossolo Vermelho Amarelo textura média.

Tabela 4. Características morfológicas dos solos estudados.

\begin{tabular}{|c|c|c|c|c|c|}
\hline Horizonte & $\begin{array}{l}\text { Prof. } \\
\text { (cm) }\end{array}$ & $\begin{array}{l}\text { Cor }^{(1)} \\
\text { (úmido) }\end{array}$ & Textura $^{(2)}$ & $\begin{array}{c}\text { Estrutura }^{(3)} \\
\mathrm{G} / \mathrm{C} / \mathrm{T}\end{array}$ & $\begin{array}{c}\text { Consistência }^{(4)} \\
\text { S/U/M }\end{array}$ \\
\hline \multicolumn{6}{|c|}{ Sistema Agroflorestal } \\
\hline Ap & $0-10$ & $5 Y R 3 / 3$ & md -arg. & $\mathrm{Mo} / \mathrm{BS} / \mathrm{G}$ & $\mathrm{LD} / \mathrm{MF} / \mathrm{LP}, \mathrm{LPe}$ \\
\hline $\mathrm{AB}$ & $11-31$ & 5YR3/4 & md - arg. & $\mathrm{Mo} / \mathrm{BS} / \mathrm{G}$ & $\mathrm{D} / \mathrm{MF} / \mathrm{LP}, \mathrm{LPe}$ \\
\hline $\mathrm{Bw}_{1}$ & $32-58$ & 5YR3/4 & md -arg. & $\mathrm{Fr} / \mathrm{BS} / \mathrm{M}$ & $\mathrm{Ma} / \mathrm{MF} / \mathrm{P}, \mathrm{Pe}$ \\
\hline $\mathrm{Bw}_{2}$ & $59-117$ & $2,5 Y R 4 / 4$ & md - arg. & Fo / Gr / MP & $\mathrm{Ma} / \mathrm{F} / \mathrm{P}, \mathrm{Pe}$ \\
\hline $\mathrm{Bw}_{3}$ & $118-+$ & $2,5 Y R 4 / 4$ & arg. & Fo / Gr / MP & $\mathrm{Ma} / \mathrm{MF} / \mathrm{P}, \mathrm{Pe}$ \\
\hline \multicolumn{6}{|c|}{ Cerrado } \\
\hline A & $0-15$ & $2,5 \mathrm{YR} 3 / 4$ & $\mathrm{md}-\arg$ & $\mathrm{Fr} / \mathrm{BS} / \mathrm{M}$ & $\mathrm{Ma} / \mathrm{F} / \mathrm{LP}, \mathrm{LPe}$ \\
\hline $\mathrm{BA}$ & $16-49$ & $5 Y R 4 / 8$ & md - arg. & $\mathrm{Fr} / \mathrm{BS} / \mathrm{M}$ & $\mathrm{LD} / \mathrm{F} / \mathrm{LP}, \mathrm{LPe}$ \\
\hline$B w_{1}$ & $50-77$ & $5 Y R 4 / 8$ & md - arg. & $\mathrm{Fr} / \mathrm{BS} / \mathrm{M}$ & $\mathrm{Ma} / \mathrm{MF} / \mathrm{LP}, \mathrm{LPe}$ \\
\hline$B w_{2}$ & $78-+$ & $5 Y R 4 / 8$ & arg. & $\mathrm{Fo} / \mathrm{Gr} / \mathrm{MP}$ & $\mathrm{Ma} / \mathrm{MF} / \mathrm{LP}, \mathrm{LPe}$ \\
\hline
\end{tabular}

Legenda:

1. Cor: 5YR3/3, 3/4 e 4/4; 2,5YR 3/4: bruno avermelhado escuro; 5 YR 4/8: vermelho amarelo.

2. Textura: md - arg: média-argilosa; arg.: argilosa

3. Estrutura: $(G=$ grau $)$ Mo: moderada; Fo: forte; Fr: fraca; $(C=$ classe $)$ BS: blocos subangulares; Gr: granular. ( $T=\operatorname{tamanho}$ ) G: grande; $M$ : média; MP: muito pequena.

4. Consistência: $(S=$ seco) LD: ligeiramente duro; D: duro; Ma: macio; (U=úmido) F: friável; MF: muito friável; (M=molhado) P: plástico; LP: ligeiramente plástico; Pe: pegajoso; Lpe: ligeiramente pegajoso.

Os perfis em ambos tratamentos apresentavam, portanto, boa agregação e porosidade, garantindo boa aeração e infiltração da água. Apesar disso, observou-se ligeira compactação no solo sob cultivo em aléias na camada entre 10 e 15 
cm. Isso foi resultante da movimentação excessiva de máquinas e da operação de gradagem.

A análise granulométrica evidenciou uniformidade textural nos perfis, com ligeiro gradiente. A quantidade de argila aumenta progressivamente com a profundidade (Tabela 5). A textura média em superficie pode implicar em maior suscetibilidade à erosão, especialmente nos locais de maior declive e sem cobertura de solo. No sistema agroflorestal, embora haja preparo de solo, deixando a superfície descoberta em parte do ano, não foram observados sinais de erosão (laminar e em sulcos). Isso em função da agregação do solo e da proteção oferecida pela leucena.

Tabela 5. Composição granulométrica dos solos $\mathrm{em}^{\mathrm{g} \mathrm{kg}^{-1}}$.

\begin{tabular}{|c|c|c|c|c|c|c|}
\hline \multirow[b]{2}{*}{ Horizonte } & \multirow{2}{*}{$\begin{array}{l}\text { Profundidade } \\
(\mathrm{cm})\end{array}$} & \multicolumn{3}{|c|}{ Areia } & \multirow[b]{2}{*}{ Silte } & \multirow[b]{2}{*}{ Argila } \\
\hline & & Grossa & Fina & Total & & \\
\hline \multicolumn{7}{|c|}{ Sistema agroflorestal } \\
\hline$A p$ & $(0-10$ & 240 & 400 & 640 & 60 & 300 \\
\hline$B A$ & $|1-3|$ & 230 & $410-$ & 640 & 60) & 300 \\
\hline$B w_{1}$ & $32-58$ & 220 & 390 & 610 & 50 & 340 \\
\hline $\mathrm{Bw}_{2}$ & $59-117$ & 200 & 400 & 600 & 60 & 340 \\
\hline $\mathrm{Bw}_{3}$ & $118-200$ & 100 & 500 & 600 & 40 & 360 \\
\hline \multicolumn{7}{|c|}{ Cerrado } \\
\hline A & $0-15$ & 220 & 440 & 680 & 60 & 240 \\
\hline $\mathrm{AB}$ & $16-49$ & 180 & 510 & 690 & 60 & 270 \\
\hline $\mathrm{Bw}_{1}$ & $50-77$ & 160 & 490 & 650 & 40 & 300 \\
\hline $\mathrm{Bw}_{2}$ & $78-200$ & 160 & 440 & 600 & 80 & 350 \\
\hline
\end{tabular}

Do ponto de vista químico, os solos eram ácidos e de baixa fertilidade. $\mathrm{O} \mathrm{pH}$ era baixo em ambos os perfis, mas na camada superficial $(0 \mathrm{a} 10 \mathrm{~cm})$, havia ligeira elevação, devido à adição contínua de resíduos orgânicos e, eventualmente, pelo efeito residual da calagem no cultivo em aléias, realizada em 1987 (Tabela 6). O teor de $\mathrm{Al}$ trocável era alto, exceto na camada superficial do sistema agrollorestal. 
Apesar do conteúdo de argila ser médio (até $360 \mathrm{~g} \mathrm{~kg}^{-1}$ ), a reserva de nutrientes era baixa em função do predomínio de argilas de baixa atividade.

Observou-se maiores teores de matéria orgânica nos primeiros $40 \mathrm{~cm}$ do solo, passando de 13 à $19 \mathrm{~g} \mathrm{~kg}^{-1}$ no cerrado, para 22 à $29 \mathrm{~g} \mathrm{~kg}^{-1}$ no sistema agroflorestal. Este incremento pode ser explicado pelo maior aporte anual de carbono, a partir da fitomassa da leucena (poda), serapilheira e dos restos culturais. Conjuntamente com os teores de carbono orgânico, notou-se elevação da CTC no solo sob cultivo em aléias. Do ponto de vista agronômico, tais fatores contribuem para maior disponibilidade de nutrientes para as plantas, além da redução das perdas.

Tabela 6. Atributos químicos dos solos no sistema agroflorestal e cerrado.

\begin{tabular}{|c|c|c|c|c|c|c|c|c|c|c|}
\hline Prof. $(\mathrm{cm})$ & $\mathrm{pH} \mathrm{CaCl}{ }_{2}$ & MO & $\mathrm{N}$ & $P$ & $\mathrm{~K}$ & $\mathrm{Ca}$ & $\mathrm{Mg}$ & $\mathrm{Al}$ & CTC & $\bar{V}$ \\
\hline & & \multicolumn{2}{|c|}{$--\mathrm{g} \mathrm{kg}^{-1}--$} & $\mu \mathrm{g} \mathrm{cm}^{-3}$ & \multicolumn{5}{|c|}{$\mathrm{mmol}_{\mathrm{c}} \mathrm{dm}^{-3}$} & $(\%)$ \\
\hline \multicolumn{11}{|c|}{ Sistema agroflorestal } \\
\hline $0-5$ & 4,6 & 29 & 1,2 & 10 & 0,6 & 24 & 12 & 2 & 65 & 57 \\
\hline $5-10$ & 4,7 & 28 & 1,4 & 9 & 0,5 & 25 & 12 & 2 & 72 & 53 \\
\hline $10-20$ & 4,4 & 22 & 1,2 & 3 & 0,8 & 17 & 10 & 4 & 62 & 45 \\
\hline $20-40$ & 4,0 & 19 & 2,3 & 2 & 0,6 & 5 & 4 & 4 & 48 & 21 \\
\hline $100-110$ & 4,4 & 13 & 1,0 & 3 & 0,6 & 3 & 3 & 6 & 35 & 20 \\
\hline $150-160$ & 4,3 & 9 & 0,7 & 1 & 0,4 & 2 & 2 & 6 & 29 & 14 \\
\hline \multicolumn{11}{|c|}{ Cerrado } \\
\hline $0-5$ & 3,8 & 19 & 0,9 & 3 & 0,8 & 4 & 2 & 8 & 49 & 14 \\
\hline $5-10$ & 3,8 & 13 & 0,8 & 2 & 0,7 & 2 & 1 & 6 & 35 & 11 \\
\hline $10-20$ & 3,9 & 13 & 0,7 & 1 & 0,4 & 1 & 1 & 7 & 36 & 6 \\
\hline $20-40$ & 4,2 & 14 & 0,4 & 1 & 0,3 & 1 & 1 & 8 & 24 & 8 \\
\hline $100-110$ & 3,9 & 17 & 0,4 & 1 & 0,5 & 1 & 1 & 8 & 41 & 7 \\
\hline $150-160$ & 3,7 & 8 & 0,4 & 2 & 0,5 & 1 & 1 & 6 & 21 & 14 \\
\hline
\end{tabular}

A matéria orgânica no solo de cerrado acumulou-se na camada superficial $(0-5 \mathrm{~cm})$, devido à queda da serapilheira. 
Constou-se, ainda, no sistema agroflorestal, maiores teores de nitrogênio total ( $0-40 \mathrm{~cm}$ de profundidade). Possivelmente, devido à fixação simbiótica através da leucena e das leguminosas usadas como adubo verde. O potássio apresentava teores semelhantes aos do cerrado, em função da maior exportação através dos grãos colhidos e perdas por erosão e lixiviação.

Verifica-se nove anos da implantação do sistema agroflorestal, teores de nutrientes no solo superiores ao cerrado. Isso se deve, além da aplicação de insumos, à capacidade de reciclagem da leucena e as culturas usadas como adubo verde. Esse sistema proporciona ainda, maior fixação de nitrogênio e maior aporte de carbono orgânico ao solo. Contudo, os teores de $\mathrm{P}, \mathrm{K}, \mathrm{Mg}$ e Ca mantiveram-se em níveis baixos a muito baixos, exceto para o $\mathrm{Mg}$ na camada superficial.

\subsection{Componentes hídricos.}

A precipitação incidente contém nutrientes solúveis, na forma de poeira e cinzas suspensas na atmosfera, constituindo a entrada externa ao sistema. $O$ gotejamento de copa e o fluxo de caule auxiliam na reciclagem interna entre a planta e o solo. A água da chuva atinge a copa e dissolve os nutrientes nos tecidos vegetais e lava a poeira retida nas folhas, transferindo-os ao solo.

\subsubsection{Precipitação incidente.}

A precipitação total anual foi de $1447 \mathrm{~mm}$, sendo $361 \mathrm{~mm}$ durante a estação seca (jun-out./1995) e 1086 mm no período das águas (nov./1995 a maio/1996).

A distribuição mensal da chuva (Figura 4) indica um período seco de abril a agosto. O período mais chuvoso foi de outubro a março, com $1159 \mathrm{~mm}$, ou seja, $80,1 \%$ do total anual. As maiores precipitações ocorreram em dezembro e março com 263 e $248 \mathrm{~mm}$, respectivamente.

A concentração média de nutrientes na precipitação foi de $1,09 \mathrm{mg} \mathrm{L}^{-1}$ de $\mathrm{N}, 0,19 \mathrm{mg} \mathrm{L}^{-1}$ de $\mathrm{P}, 0,37 \mathrm{mg} \mathrm{L}^{-1}$ de $\mathrm{K}, 0,90 \mathrm{mg} \mathrm{L}^{-1}$ de Ca e $0,17 \mathrm{mg} \mathrm{L}^{-1}$ de $\mathrm{Mg}$ (Tabela 7). O maior teor de nutrientes ocorreu no periodo seco, havendo uma relação 
inversa com a altura de chuva. Este fato já foi observado em São Paulo (Meguro et al., 1979) e Mogi-Guaçú, SP (Meguro \& Delitti, 1985).

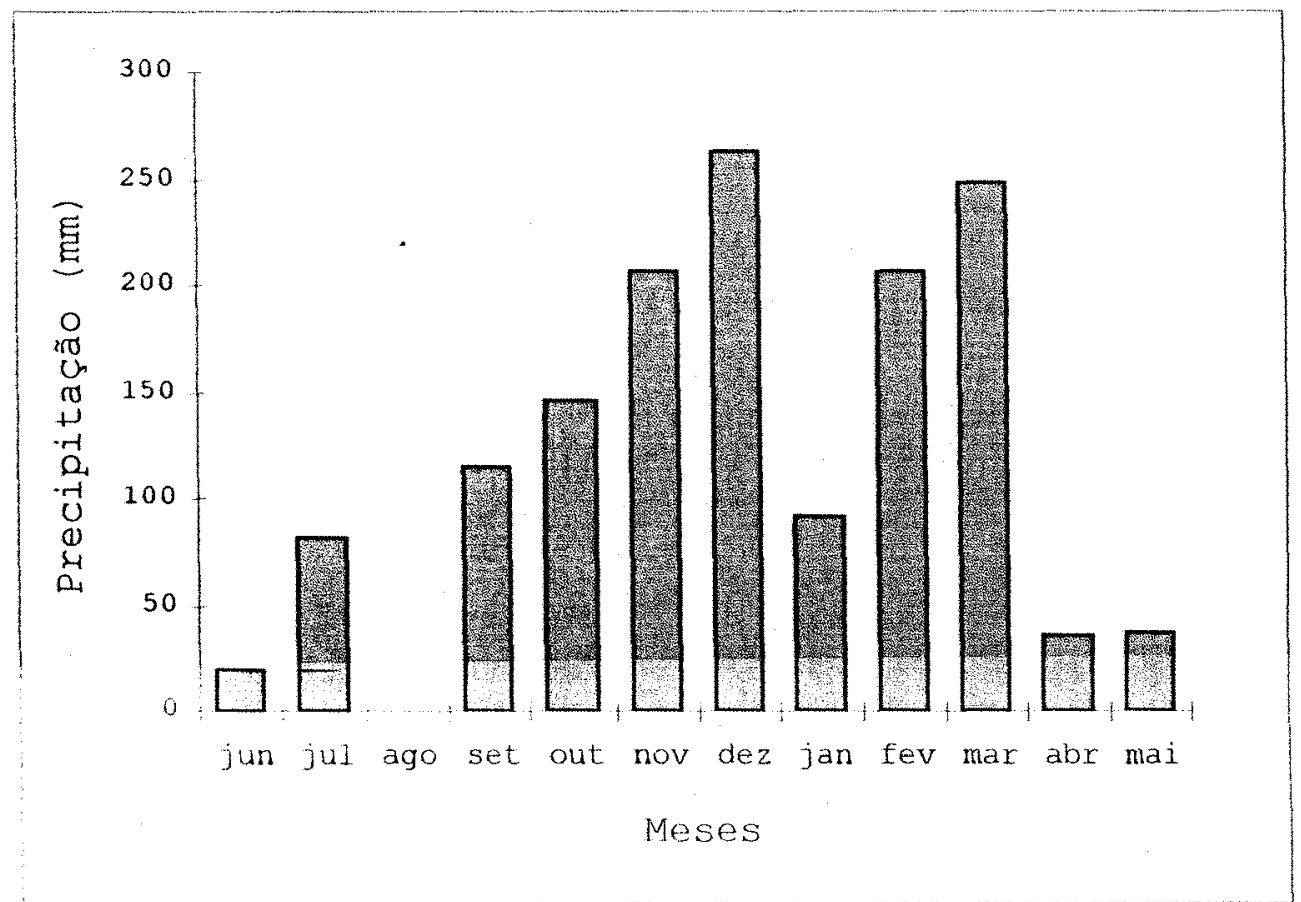

Figura 4. Variação mensal da precipitação em Botucatu.

Tabela 7. Concentração de nutrientes $\left(\mathrm{mg} \mathrm{L}^{-1}\right)$ na precipitação incidente.

\begin{tabular}{lccccc}
\hline Período & N & P & K & Ca & Mg \\
\hline Inverno & 2,48 & 0,36 & 0,88 & 0,82 & 0,31 \\
Verão & 0,63 & 0,14 & 0,20 & 0,92 & 0,12 \\
Média & 1,09 & 0,19 & 0,37 & 0,90 & 0,17 \\
\hline
\end{tabular}

A adição total de nutrientes pela chuva foi de $15,5 \mathrm{~kg} \mathrm{ha}^{-1}$ de $\mathrm{N}, 2,82$ $\mathrm{kg} \mathrm{ha}^{-1}$ de P, 5,35 kg ha ${ }^{-1}$ de $\mathrm{K}, 13,0 \mathrm{~kg} \mathrm{ha}^{-1}$ de Ca e 2,42 $\mathrm{kg} \mathrm{ha}^{-1}$ de Mg (Tabela 8). Tais valores são similares aos valores médios anuais observados em áreas de florestas tropicais úmidas: $10,9 \mathrm{~kg} \mathrm{ha}^{-1}$ de $\mathrm{N}, 3,0 \mathrm{~kg} \mathrm{ha}^{-1}$ de $\mathrm{P}, 7,7 \mathrm{~kg} \mathrm{ha}^{-1} \mathrm{de} \mathrm{K}, 11,9 \mathrm{~kg} \mathrm{ha}^{-1} \mathrm{de} \mathrm{Ca}$ e 4,7 $\mathrm{kg} \mathrm{ha}^{-1}$ de Mg (Vitousek \& Sanford, 1991). 


\subsubsection{Gotejamento de copa.}

O total anual foi de $1330 \mathrm{~mm}$ no cerrado e $1333 \mathrm{~mm}$ no sistema agroflorestal. Observou-se uma relação direta entre a precipitação incidente e o gotejamento de copa, que em média nas duas áreas, representou $92 \%$ da chuva (Figura 5). Para a intensidade de chuva ou época do ano, não houve correlação significativa.

Tabela 8. Altura precipitada $(\mathrm{mm})$ e nutrientes adicionados $\left(\mathrm{kg} \mathrm{ha}^{-1}\right)$ pela chuva.

\begin{tabular}{lccc}
\hline Atributo & Inverno & Verão & Total \\
\hline Altura & 361 & 1086 & 1447 \\
$\mathrm{~N}$ & 8,96 & 6,52 & 15,47 \\
$\mathrm{P}$ & 1,30 & 1,52 & 2,82 \\
$\mathrm{~K}$ & 3,18 & 2,17 & 5,35 \\
$\mathrm{Ca}$ & 2,96 & 9,99 & 12,95 \\
$\mathrm{Mg}$ & 1,12 & 1,30 & 2,42 \\
\hline
\end{tabular}

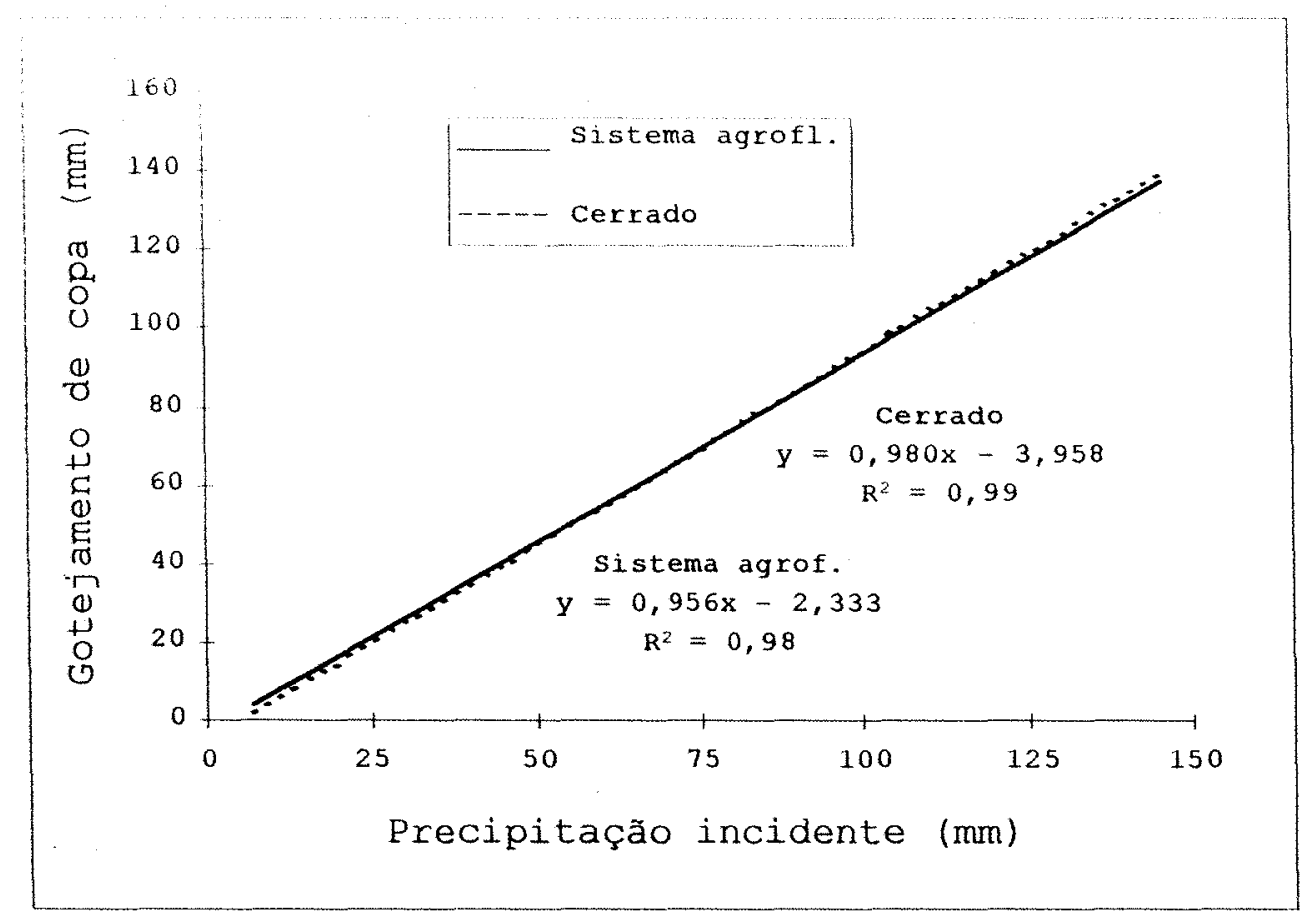

Figura 5. Relação entre precipitação incidente e gotejamento de copa. 
O gotejamento de copa varia com a densidade da cobertura vegetal. Em floresta densa na China, com índice de área foliar de 8,4 e biomassa de $290 \mathrm{t} \mathrm{ha}^{-1}$, representou de 70 a $95 \%$ da chuva total (Wang et al., 1994). Já num campo cerrado em Mogi-Guaçú (SP), teve-se uma proporção de $89 \%$ da chuva total (Pompéia, 1989).

A concentração média no gotejamento de copa foi de $1,49 \mathrm{mg} \mathrm{L}^{-1}$ de $\mathrm{N}, 0,42 \mathrm{mg} \mathrm{L}^{-1}$ de $\mathrm{P}, 0,61 \mathrm{mg} \mathrm{L}^{-1}$ de $\mathrm{K}, 2,03 \mathrm{mg} \mathrm{L}^{-1}$ de Ca e $0,21 \mathrm{mg} \mathrm{L}^{-1}$ de $\mathrm{Mg}$ no cerrado. No sistema agroflorestal os valores obtidos foram $1,49 \mathrm{mg} \mathrm{L}^{-1} \mathrm{de} \mathrm{N}, 0,46 \mathrm{mg} \mathrm{L}^{-1}$ de $\mathrm{P}, 0,73 \mathrm{mg} \mathrm{L}^{-1}$ de $\mathrm{K}, 2,23 \mathrm{mg} \mathrm{L}^{-1}$ de Ca e $0,37 \mathrm{mg} \mathrm{L}^{-1}$ de $\mathrm{Mg}$ (Tabela 9).

Tabela 9. Concentração de nutrientes $\left(\mathrm{mg} \mathrm{L}^{-1}\right)$ na solução do gotejamento de copa.

\begin{tabular}{lcccccc}
\hline & \multicolumn{3}{c}{ Cerrado } & \multicolumn{3}{c}{ Sistema agroflorestal } \\
\cline { 2 - 7 } Nutrientes & Inverno $^{(1)}$ & Verão & Média $^{(2)}$ & Inverno $^{(1)}$ & Verão & Média $^{(2)}$ \\
\hline $\mathrm{N}$ & 3,56 & $\mathbf{0 , 8 2}$ & $\mathbf{1 , 4 9 \pm 0 , 1 5}$ & $\mathbf{3 , 1 4}$ & $\mathbf{0 , 9 3}$ & $1,49 \pm 0,12$ \\
$\mathrm{P}$ & 1,16 & 0,18 & $0,42 \pm 0,10$ & 1,20 & 0,21 & $0,46 \pm 0,11$ \\
$\mathrm{~K}$ & 1,73 & 0,24 & $0,61 \pm 0,15$ & 1,91 & 0,33 & $0,73 \pm 0,18$ \\
$\mathrm{Ca}$ & $2,38 *$ & 1,90 & $2,03 \pm 0,48$ & $3,81 *$ & 1,70 & $2,23 \pm 0,20$ \\
$\mathrm{Mg}$ & $0,47^{* *}$ & 0,27 & $0,21 \pm 0,02$ & $1,13 * *$ & 0,12 & $0,37 \pm 0,09$ \\
\hline
\end{tabular}

1. * = significativo com $95 \%$ de confiança; $* *=$ significativo com $99 \%$ de confiança;

2. Intervalo de confiança com $5 \%$ de significância.

Os teores de $\mathrm{Ca}$ e $\mathrm{Mg}$ no gotejamento de copa no inverno, foram significativamente maiores no cultivo em aléias, em função da maior concentração de nutrientes na fitomassa da leucena.

O gotejamento de copa foi 1,4 a 2,4 vezes mais concentrado em nutrientes que a chuva (precipitação) incidente. Este enriquecimento se deve a solubilização dos nutrientes presentes nas folhas e a lavagem da poeira depositada na copa. A vegetação age como um filtro para as partículas em suspensão na atmosfera, que são colóides orgânicos e inorgânicos e cinzas, provenientes das queimadas realizadas na região, os quais são ricos em nutrientes. 
Esse fenômeno já foi verificado em uma mata tropical subcaducifólia em Fênix (PR), onde o gotejamento de copa foi 2 a 11 vezes mais rico em nutrientes que a precipitação incidente (Santos \& Rodrigues, 1992).

A adição de nutrientes pelo gotejamento de copa no cerrado atingiu $5,30 \mathrm{~kg} \mathrm{ha}^{-1}$ de N, 3,01 $\mathrm{kg} \mathrm{ha}^{-1}$ de P, 3,18 $\mathrm{kg} \mathrm{ha}^{-1}$ de K, 14,93 $\mathrm{kg} \mathrm{ha}^{-1}$ de Ca e 2,03 kg ha${ }^{1}$ de Mg. No sistema agroflorestal contribuiu com 5,20 kg ha ${ }^{-1} \mathrm{de} \mathrm{N}, 2,91 \mathrm{~kg} \mathrm{ha}^{-1}$ de $\mathrm{P}$, $4,74 \mathrm{~kg} \mathrm{ha}^{-1}$ de K, $17,77 \mathrm{~kg} \mathrm{ha}^{-1}$ de Ca e 2,84 $\mathrm{kg} \mathrm{ha}^{-1}$ de Mg (Tabela 10).

Os valores médios encontrados em outras florestas tropicais, ocorrendo em solos pobres em nutrientes, são de $18,0 \mathrm{~kg} \mathrm{ha}^{-1} \mathrm{de} \mathrm{N}, 2,0 \mathrm{~kg} \mathrm{ha}^{-1} \mathrm{de} \mathrm{P,} \mathrm{43,0}$ $\mathrm{kg} \mathrm{ha}^{-1} \mathrm{de} \mathrm{K}, 13,0 \mathrm{~kg} \mathrm{ha}^{-1}$ de Ca e 17,6 kg ha ${ }^{-1} \mathrm{de} \mathrm{Mg}$ (Vitousek \& Sanford, 1986).

\subsubsection{Fluxo de caule.}

O fluxo de caule acumulado durante o ano atingiu $31 \mathrm{~mm}$ no cerrado, representando $2,1 \%$ da precipitação incidente. Isso foi significativamente superior ao sistema agroflorestal, onde escoaram $12 \mathrm{~mm}$ anuais, ou seja, $0,8 \%$ da precipitação (Figura 6).

Não houve correlação significativa entre a precipitação incidente e o fluxo de caule conforme a época do ano. Outro aspecto relevante, foi a reduzida participação em relação ao total precipitado. Isso também foi notado, mesmo em florestas densas como a amazônica, em que essa proporção não excedeu a 8 \% da chuva total (Jordan \& Heuveldop, 1981). Em outro trabalho, numa floresta tropical na China, com índice de área foliar de $8,4 \mathrm{e}$ biomassa de $290 \mathrm{t} \mathrm{ha}^{-1}$, o valor médio encontrado foi menor que $5 \%$ da precipitação incidente (Wang et al., 1994).

Houve correlação significativa ( $99 \%$ de confiança) entre a chuva e o fluxo de caule nas duas áreas, o que não ocorreu para as características de planta (diâmetro à $60 \mathrm{~cm}$ de altura e altura; Tabela 11). Em uma floresta subcaducifólia (Fênix, PR), notou-se também a ausência de correlação entre o fluxo de caule e o diâmetro das árvores. Contudo, verificou-se que as plantas de copa densa e casca lisa apresentaram maior volume de fluxo de caule (Santos, 1988). 
Tabela 10. Altura (mm) e adição de nutrientes $\left(\mathrm{kg} \mathrm{ha}^{-1}\right)$ pelo gotejamento de copa.

\begin{tabular}{|c|c|c|c|c|c|c|}
\hline Mês & Altura (mm) & $\mathbf{N}$ & $\mathbf{P}$ & $\mathbf{K}$ & $\overline{\mathbf{C a}}$ & $\mathbf{M g}$ \\
\hline \multicolumn{7}{|c|}{ Cerrado } \\
\hline Jun & 17,0 & 0,18 & 0,14 & 0,14 & 0,27 & 0,03 \\
\hline Jul & 72,0 & 0,75 & 0,58 & 0,61 & 1,12 & 0,12 \\
\hline Set & 98,2 & 1,02 & 0,79 & 0,83 & 1,53 & 0,16 \\
\hline Out & 139,2 & 1,45 & 1,11 & 1,18 & 2,17 & 0,22 \\
\hline Nov & 181,5 & 0,34 & 0,07 & 0,07 & 1,78 & 0,27 \\
\hline Dez & 250,6 & 0,48 & 0,10 & 0,10 & 2,46 & 0,38 \\
\hline Jan & 70,1 & 0,13 & 0,03 & 0,03 & 0,69 & 0,11 \\
\hline Fev & 199,1 & 0,38 & 0,08 & 0,08 & 1,95 & 0,30 \\
\hline Mar & 244,5 & 0,46 & 0,10 & 0,10 & 2,40 & 0,37 \\
\hline $\mathrm{Abr}$ & 34,9 & 0,07 & 0,01 & 0,01 & 0,34 & 0,05 \\
\hline Maio & 23,3 & 0,04 & 0,01 & 0,01 & 0,23 & 0,03 \\
\hline SOMA & 1330,40 & 5,30 & 3,01 & 3,18 & 14,93 & 2,03 \\
\hline \multicolumn{7}{|c|}{ Sistema agroflorestal } \\
\hline Jun & 17,5 & 0,116 & 0,147 & 0,180 & 0,523 & 0,144 \\
\hline Jul & 77,9 & 0,514 & 0,654 & 0,802 & 2,328 & 0,638 \\
\hline Set & 99,4 & 0,656 & 0,835 & 1,024 & 2,971 & 0,815 \\
\hline Out & 139,3 & 0,919 & 1,170 & 1,434 & 4,164 & 1,142 \\
\hline Nov & 173,1 & 0,519 & 0,017 & 0,225 & 1,350 & 0,017 \\
\hline Dez & 247,2 & 0,742 & 0,025 & 0,321 & 1,928 & 0,025 \\
\hline Jan & 72,7 & 0,218 & 0,007 & 0,095 & 0,567 & 0,007 \\
\hline Fev & 197,0 & 0,591 & 0,020 & 0,256 & 1,537 & 0,020 \\
\hline Mar & 245,7 & 0,737 & 0,025 & 0,319 & 1,916 & 0,025 \\
\hline $\mathrm{Abr}$ & 34,8 & 0,104 & 0,003 & 0,045 & 0,271 & 0,003 \\
\hline Maio & 27,7 & 0,083 & 0,003 & 0,036 & 0,216 & 0,003 \\
\hline SOMA & 1333,0 & 5,20 & 2,91 & 4,74 & 17,77 & 2,84 \\
\hline
\end{tabular}




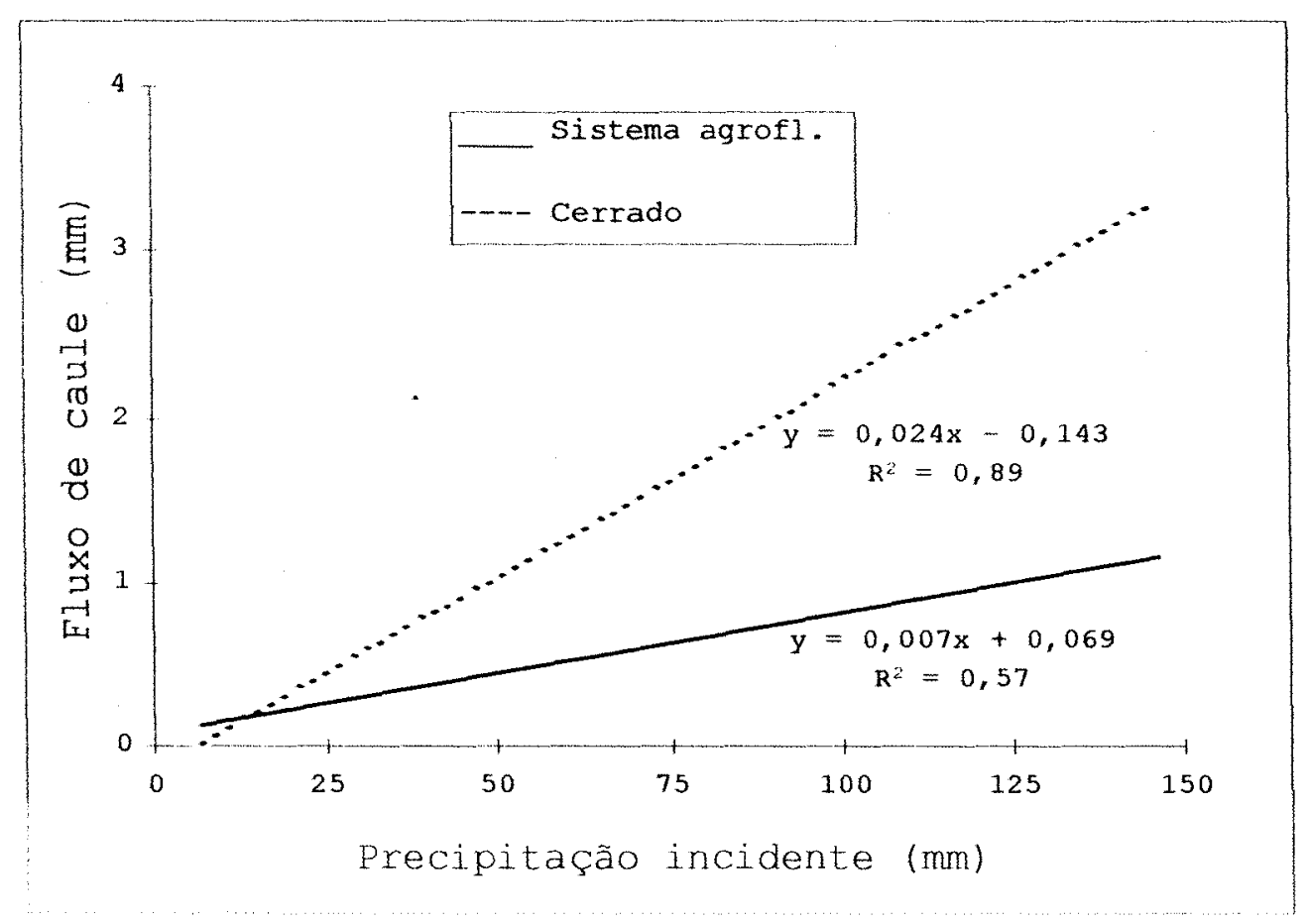

Figura 6. Relação entre precipitação incidente e fluxo de caule.

Tabela 11. Coeficientes de correlação ( $r$ ) para o fluxo de caule.

\begin{tabular}{lcc}
\hline Atributo & Cerrado & Sistema agroflorestal \\
\hline Precipitação incidente & $0,76^{* *}$ & $0,94^{* *}$ \\
Diâmetro de plantas & 0,50 & 0,00 \\
Altura de plantas & 0,46 & 0,58 \\
\hline
\end{tabular}

** = significativo com $99 \%$ de confiança.

A concentração média de nutrientes no fluxo de caule do cerrado foi de $1,86 \mathrm{mg} \mathrm{L}^{-1}$ de $\mathrm{N}, 0,85 \mathrm{mg} \mathrm{L}^{-1}$ de $\mathrm{P}, 2,00 \mathrm{mg} \mathrm{L}^{-1}$ de K, $1,39 \mathrm{mg} \mathrm{L}^{-1}$ de Ca e 0,46 mg $\mathrm{L}^{-1}$ de $\mathrm{Mg}$. No sistema agroflorestal encontrou-se valores médios de $2,03 \mathrm{mg} \mathrm{L}^{-1}$ de $\mathrm{N}$, $1,17 \mathrm{mg} \mathrm{L}^{-1}$ de $\mathrm{P}, 8,62 \mathrm{mg} \mathrm{L}^{-1}$ de $\mathrm{K}, 1,69 \mathrm{mg} \mathrm{L}^{-1}$ de Ca e 1,70 $\mathrm{mg} \mathrm{L}^{-1}$ de $\mathrm{Mg}$ (Tabela 12). As diferenças significativas entre as áreas ocorreram com o $\mathrm{P}, \mathrm{K}, \mathrm{Ca} \mathrm{e} \mathrm{Mg}$ no inverno e $\mathrm{K} \mathrm{e} \mathrm{Mg} \mathrm{no} \mathrm{verão,} \mathrm{sendo} \mathrm{mais} \mathrm{concentrada} \mathrm{a} \mathrm{solução} \mathrm{colhida} \mathrm{no} \mathrm{cultivo} \mathrm{em} \mathrm{aléias.}$ 
Tabela 12. Concentração de nutrientes $\left(\mathrm{mg} \mathrm{L}^{-1}\right)$ na solução do fluxo de caule.

\begin{tabular}{lllllll}
\hline & \multicolumn{3}{c}{ Cerrado } & \multicolumn{3}{c}{ Sistema agroflorestal } \\
\cline { 2 - 7 } Nutrientes & Inverno $^{(1)}$ & Verão $^{(1)}$ & Média $^{(2)}$ & Inverno $^{(1)}$ & Verão $^{(1)}$ & Média $^{(2)}$ \\
\hline $\mathrm{N}$ & 4,64 & 0,87 & $1,86 \pm 0,20$ & 4,17 & 1,05 & $2,03 \pm 0,33$ \\
$\mathrm{P}$ & $0,84^{* *}$ & 0,86 & $0,85 \pm 0,26$ & $2,22^{* *}$ & 0,69 & $1,17 \pm 0,30$ \\
$\mathrm{~K}$ & $3,57^{* *}$ & $1,44^{* *}$ & $2,00 \pm 0,55$ & $14,76^{* *}$ & $5,81^{* *}$ & $8,62 \pm 1,65$ \\
$\mathrm{Ca}$ & $1,47^{* *}$ & 1,08 & $1,39 \pm 0,57$ & $2,04 * *$ & 1,53 & $1,69 \pm 0,24$ \\
$\mathrm{Mg}$ & $0,91^{* *}$ & $0,30^{* *}$ & $0,46 \pm 0,14$ & $2,08^{* *}$ & $1,53^{* *}$ & $1,70 \pm 0,50$ \\
\hline
\end{tabular}

1. ${ }^{*}$ significativo $(\alpha=0,05) ;{ }^{* *}$ significativo $(\alpha=0,01) ; 2$. Intervalo de confiança a $5 \%$.

Em relação à chuva incidente, houve um enriquecimento em nutrientes de 1,7 a 23,2 vezes na solução escoada pelo caule. Numa floresta tropical subcaducifólia, em Fênix, PR, essa relação foi de 5 a 16 vezes (Santos \& Rodrigues, 1992).

A adição total de nutrientes pelo fluxo de caule foi de $0,23 \mathrm{~kg} \mathrm{ha}^{-1}$ de $\mathrm{N}, 0,21 \mathrm{~kg} \mathrm{ha}^{-1}$ de P, 0,51 $\mathrm{kg} \mathrm{ha}^{-1}$ de K, 0,09 $\mathrm{kg} \mathrm{ha}^{-1}$ de Ca e $0,11 \mathrm{~kg} \mathrm{ha}^{-1}$ de Mg no cerrado. No sistema agroflorestal representou $0,10 \mathrm{~kg} \mathrm{ha}^{-1}$ de $\mathrm{N}, 0,12 \mathrm{~kg} \mathrm{ha}^{-1}$ de $\mathrm{P}, 1,00$ $\mathrm{kg} \mathrm{ha}^{-1}$ de K, 0,10 $\mathrm{kg} \mathrm{ha}^{-1}$ de Ca e $0,19 \mathrm{~kg} \mathrm{ha}^{-1}$ de $\mathrm{Mg}$ (Tabela 13).

$\mathrm{A}$ adição anual de $\mathrm{N}$ foi maior no cerrado em função do maior volume escoado. Para o $\mathrm{K} \mathrm{e} \mathrm{Mg}$, observou-se maior contribuição no sistema agroflorestal, devido à maior concentração na solução.

\subsubsection{Interceptação.}

A fração da chuva que ficou retida na copa da vegetação foi de $86 \mathrm{~mm}$ no cerrado, representando $5,9 \%$ da precipitação incidente. No sistema agroflorestal, a interceptação totalizou $102 \mathrm{~mm}$, ou 7,0 \% da chuva total.

Não foi encontrada correlação significativa ( $95 \%$ de confiança) entre a precipitação incidente e interceptação. A variabilidade foi provocada pela intensidade de chuva e pelo efeito do vento. 
Tabela 13. Altura (mm) e nutrientes adicionados $\left(\mathrm{kg} \mathrm{ha}^{-1}\right)$ pelo fluxo de caule.

\begin{tabular}{|c|c|c|c|c|c|c|}
\hline Mês & Altura (mm) & $\mathbf{N}$ & $\mathbf{P}$ & $\mathbf{K}$ & $\mathbf{C a}$ & Mg \\
\hline \multicolumn{7}{|c|}{ Cerrado } \\
\hline Jun & 0,38 & 0,008 & 0,002 & 0,010 & 0,002 & 0,002 \\
\hline Jul & 2,21 & 0,048 & 0,011 & 0,059 & 0,014 & 0,013 \\
\hline Set & 2,31 & 0,050 & 0,011 & 0,062 & 0,015 & 0,014 \\
\hline Out & 3,39 & 0,073 & 0,016 & 0,091 & 0,022 & 0,020 \\
\hline Nov & 4,34 & 0,010 & 0,031 & 0,054 & 0,007 & 0,008 \\
\hline Dez & 5,59 & 0,013 & 0,040 & 0,069 & 0,009 & 0,017 \\
\hline Jan & 1,48 & 0,004 & 0,011 & 0,018 & 0,002 & 0,004 \\
\hline Fev & 4,03 & 0,010 & 0,029 & 0,050 & 0,006 & 0,012 \\
\hline Mar & 6,69 & 0,016 & 0,048 & 0,083 & 0,011 & 0,020 \\
\hline Abr & 0,46 & 0,001 & 0,003 & 0,006 & 0,001 & 0,001 \\
\hline Maio & 0,29 & 0,001 & 0,002 & 0,004 & 0,000 & 0,001 \\
\hline SOMA & 31,18 & $\mathbf{0 , 2 3 4}$ & $\mathbf{0 , 2 0 5}$ & $\mathbf{0 , 5 0 7}$ & 0,091 & 0,113 \\
\hline \multicolumn{7}{|c|}{ Sistema agroflorestal } \\
\hline Jun & 0,18 & 0,003 & 0,003 & 0,025 & 0,002 & 0,003 \\
\hline Jul & 1,34 & 0,023 & 0,025 & 0,185 & 0,016 & 0,024 \\
\hline Set & 1,58 & 0,027 & 0,029 & 0,219 & 0,019 & 0,028 \\
\hline Out & 0,74 & 0,013 & 0,014 & 0,103 & 0,009 & 0,013 \\
\hline Nov & 0,68 & 0,003 & 0,004 & 0,038 & 0,004 & 0,010 \\
\hline Dez & 1,74 & 0,007 & 0,010 & 0,098 & 0,011 & 0,025 \\
\hline Jan & 0,67 & 0,003 & 0,004 & 0,038 & 0,004 & 0,009 \\
\hline Fev & 2,13 & 0,009 & 0,012 & 0,120 & 0,013 & 0,030 \\
\hline Mar & 2,61 & 0,011 & 0,014 & 0,147 & 0,016 & 0,037 \\
\hline Abr & 0,26 & 0,001 & 0,001 & 0,014 & 0,002 & 0,004 \\
\hline Maio & 0,17 & 0,001 & 0,001 & 0,010 & 0,001 & 0,003 \\
\hline SOMA & 12,12 & $\mathbf{0 , 1 0 0}$ & $\mathbf{0 , 1 1 7}$ & 0,997 & $\mathbf{0 , 0 9 7}$ & $\mathbf{0 , 1 8 5}$ \\
\hline
\end{tabular}


A quantidade de chuva interceptada depende da densidade $\mathrm{e}$ continuidade do dossel, porte e arquitetura arbórea e estratificação da floresta (Langkamp et al., 1982). Na floresta amazônica verificou-se que a interceptação variou de forma inversa com a altura de chuva. Para eventos com até $5 \mathrm{~mm}$, encontrou-se até $100 \%$ de interceptação (Jordan \& Heuveldop, 1981).

\subsubsection{Enxurrada.}

A perda anual de água por enxurrada atingiu $31 \mathrm{~mm}$ no cerrado e 7 $\mathrm{mm}$ no sistema agroflorestal, perfazendo $2,1 \%$ e $0,5 \%$ da chuva, respectivamente.

A concentração média de nutrientes na enxurrada do cerrado foi de $5,97 \mathrm{mg} \mathrm{L}^{-1}$ de $\mathrm{N}, 1,65 \mathrm{mg} \mathrm{L}^{-1}$ de $\mathrm{P}, 8,52 \mathrm{mg} \mathrm{L}^{-1}$ de K, $12,8 \mathrm{mg} \mathrm{L}^{-1}$ de Ca e $0,78 \mathrm{mg} \mathrm{L}^{-1}$ de $\mathrm{Mg}$. No sistema agroflorestal, os valores médios foram de $8,71 \mathrm{mg} \mathrm{L}^{-1}$ de $\mathrm{N}, 3,03 \mathrm{mg}$ $\mathrm{L}^{-1}$ de $\mathrm{P}, 22,26 \mathrm{mg} \mathrm{L}^{-1}$ de $\mathrm{K}, 6,68 \mathrm{mg} \mathrm{L}^{-1}$ de Ca e 3,62 $\mathrm{mg} \mathrm{L}^{-1}$ de $\mathrm{Mg}$ (Tabela 14).

Tabela 14. Concentração de nutrientes $\left(\mathrm{mg} \mathrm{L}^{-1}\right)$ na enxurrada.

\begin{tabular}{lcccccc}
\hline & \multicolumn{3}{c}{ Cerrado } & \multicolumn{3}{c}{ Sistema agroflorestal } \\
\cline { 2 - 7 } Nutrientes & Inverno & Verão & Média & Inverno & Verão & Média \\
\hline $\mathrm{N}$ & 7,92 & 4,01 & 5,79 & 11,22 & 6,20 & 8,71 \\
$\mathrm{P}$ & 2,30 & 1,00 & 1,65 & 3,80 & 2,26 & 3,03 \\
$\mathrm{~K}$ & 11,70 & 5,33 & 8,52 & 35,49 & 9,04 & 22,26 \\
$\mathrm{Ca}$ & 14,79 & 10,74 & 12,77 & 5,41 & 7,96 & 6,68 \\
$\mathrm{Mg}$ & 1,04 & 0,53 & 0,78 & 4,25 & 2,99 & 3,62 \\
\hline
\end{tabular}

A remoção total de nutrientes pela enxurrada foi de $1,38 \mathrm{~kg} \mathrm{ha}^{-1} \mathrm{de} \mathrm{N}$, $0,36 \mathrm{~kg} \mathrm{ha}^{-1} \mathrm{de} P, 1,88 \mathrm{~kg} \mathrm{ha}^{-1}$ de $\mathrm{K}, 3,48 \mathrm{~kg} \mathrm{ha}^{-1}$ de Ca e $0,18 \mathrm{~kg} \mathrm{ha}^{-1} \mathrm{de} \mathrm{Mg}$ no cerrado. No sistema agroflorestal, representou $0,49 \mathrm{~kg} \mathrm{ha}^{-1} \mathrm{de} \mathrm{N}, 0,17 \mathrm{~kg} \mathrm{ha}^{-1}$ de $\mathrm{P}, 0,93 \mathrm{~kg} \mathrm{ha}^{-1}$ de $\mathrm{K}, 0,52 \mathrm{~kg} \mathrm{ha}^{-1}$ de Ca e $0,22 \mathrm{~kg} \mathrm{ha}^{-1}$ de $\mathrm{Mg}$ (Tabela 15). As perdas de $\mathrm{N}, \mathrm{P}, \mathrm{K}$ e Ca foram maiores no cerrado, devido ao maior volume de enxurrada. 
A intensidade da erosão nos tratamentos estudados foi bem menor em relação a sistemas agrícolas com maior movimentação do solo e baixa densidade de cobertura vegetal, evidenciando o potencial das árvores de reduzirem a erosão.

Tabela 15. Perdas mensais de água $(\mathrm{mm})$ e nutrientes $\left(\mathrm{kg} \mathrm{ha}^{-1}\right)$ por enxurrada.

\begin{tabular}{ccccccc}
\hline Mês & Altura (mm) & N & $\mathbf{P}$ & $\mathbf{K}$ & $\mathbf{C a}$ & $\mathbf{M g}$ \\
\hline \multicolumn{7}{c}{ Cerrado } \\
\hline Jun & 0,12 & 0,010 & 0,003 & $\mathbf{0 , 0 1 4}$ & 0,018 & 0,001 \\
Set & 0,57 & 0,045 & 0,013 & 0,067 & 0,085 & 0,006 \\
Out & 2,81 & 0,223 & 0,065 & 0,329 & 0,416 & 0,029 \\
Nov & 3,75 & 0,150 & 0,037 & 0,200 & 0,403 & 0,020 \\
Dez & 3,11 & 0,125 & 0,031 & 0,166 & 0,334 & 0,016 \\
Jan & 0,31 & 0,012 & 0,003 & 0,016 & 0,033 & 0,002 \\
Fev & 5,57 & 0,223 & 0,056 & 0,297 & 0,598 & 0,030 \\
Mar & 14,85 & 0,595 & 0,148 & 0,791 & 1,594 & 0,079 \\
\hline SOMA & $\mathbf{3 1 , 0 8}$ & $\mathbf{1 , 3 8 3}$ & $\mathbf{0 , 3 5 6}$ & $\mathbf{1 , 8 8 0}$ & $\mathbf{3 , 4 8 0}$ & $\mathbf{0 , 1 8 3}$ \\
\hline & & Sistema agroflorestal & & \\
\hline Jun & 0,04 & 0,004 & 0,001 & 0,013 & 0,002 & 0,002 \\
Set & 0,28 & 0,031 & 0,011 & 0,098 & 0,015 & 0,012 \\
Out & $\mathbf{0 , 8 1}$ & 0,091 & 0,031 & $\mathbf{0 , 2 8 8}$ & $\mathbf{0 , 0 4 4}$ & 0,034 \\
Nov & 2,62 & 0,163 & 0,059 & $\mathbf{0 , 2 3 7}$ & 0,209 & 0,078 \\
Dez & 1,08 & 0,067 & 0,025 & 0,098 & 0,086 & 0,032 \\
Jan & 0,36 & 0,023 & 0,008 & 0,033 & 0,029 & 0,011 \\
Fev & 0,56 & 0,035 & 0,013 & 0,051 & 0,045 & 0,017 \\
Mar & $\mathbf{1 , 1 8}$ & 0,073 & 0,027 & 0,107 & 0,094 & 0,035 \\
\hline SOMA & $\mathbf{6 , 9 4}$ & $\mathbf{0 , 4 8 7}$ & $\mathbf{0 , 1 7 4}$ & $\mathbf{0 , 9 2 5}$ & $\mathbf{0 , 5 2 4}$ & $\mathbf{0 , 2 2 2}$ \\
\hline
\end{tabular}

A quantidade de solo erodido foi de $1202 \mathrm{~kg} \mathrm{ha}^{-1}$ no cerrado e $614 \mathrm{~kg}$ $\mathrm{ha}^{-1}$ no sistema agroflorestal. No sedimento foram perdidos $0,82 \mathrm{~kg} \mathrm{ha}^{-1} \mathrm{de} \mathrm{N}, 0,01 \mathrm{~kg}$ $\mathrm{ha}^{-1}$ de $\mathrm{P}, 0,02 \mathrm{~kg} \mathrm{ha}^{-1}$ de $\mathrm{K}, 0,29 \mathrm{~kg} \mathrm{ha}^{-1}$ de Ca e $0,04 \mathrm{~kg} \mathrm{ha}^{-1}$ de $\mathrm{Mg}$ no cerrado. No 


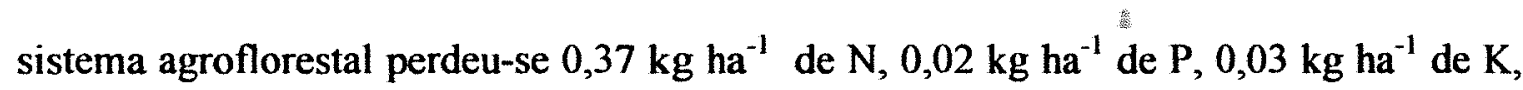
$0,35 \mathrm{~kg} \mathrm{ha}^{-1}$ de $\mathrm{Ca}$ e $0,06 \mathrm{~kg} \mathrm{ha}^{-1}$ de $\mathrm{Mg}$ (Tabela 16). Essas quantidades foram proporcionais ao volume de escoamento superficial.

Tabela 16. Solo erodido $\left(\mathrm{kg} \mathrm{ha}^{-1}\right)$ e concentração de nutrientes $\left(\mathrm{mg} \mathrm{kg}^{-1}\right)$ no sedimento.

\begin{tabular}{lcccc}
\hline & \multicolumn{2}{c}{ Cerrado } & \multicolumn{2}{c}{ Sistema agroflorestal } \\
\cline { 2 - 5 } Atributo & Concentração & Perda anual & Concentração & Perda anual \\
\hline Solo & -- & 1202 & $-\cdots$ & 614 \\
$\mathrm{~N}$ & 682,2 & 0,82 & 602,6 & 0,37 \\
$\mathrm{P}$ & 8,3 & 0,01 & 32,6 & 0,02 \\
$\mathrm{~K}$ & 16,6 & 0,02 & 48,9 & 0,03 \\
$\mathrm{Ca}$ & 241,3 & 0,29 & 570,0 & 0,35 \\
$\mathrm{Mg}$ & 33,3 & 0,04 & 97,7 & 0,06 \\
\hline
\end{tabular}

Lal (1989a) quantificou a erosão em um cultivo em aléias sobre um alfissol, na Nigéria, com declividade média de $7 \%$. As perdas de água e solo foram reduzidas em até $76 \%$ e $92 \%$, respectivamente, em comparação ao solo descoberto. Justificou que os renques controlam a erosão por duas maneiras: reduzindo a velocidade da enxurrada, diminuindo assim a capacidade de transporte de sedimentos e, por impedir a desagregação do solo pelo impacto da chuva, pois há maior cobertura. As perdas anuais de nutrientes foram inferiores a $1,0 \mathrm{~kg} \mathrm{ha}^{-1}$ de $\mathrm{N}, \mathrm{P}$ e Mg, e de até $7 \mathrm{~kg} \mathrm{ha}^{-1}$ de Ca e K.

Em outro experimento conduzido em Yurimaguas, Peru, em solo com declive de $20 \%$, a perda anual de solo em cultivo em aléias foi menor que $1000 \mathrm{~kg} \mathrm{ha}^{-1}$ (Szott et al., 1991a).

\subsubsection{Lixiviação.}

A lixiviação anual em profundidade maior do que $160 \mathrm{~cm}$, atingiu 209 mm no cerrado $(14,4 \%$ da chuva total) e $149 \mathrm{~mm}$ no sistema agroflorestal $(10,3 \% \mathrm{da}$ chuva). 
A concentração média de nutrientes na lixiviação foi de $2,26 \mathrm{mg} \mathrm{L}^{-1}$ de $\mathrm{N}, 0,52 \mathrm{mg} \mathrm{L}^{-1}$ de $\mathrm{P}, 1,33 \mathrm{mg} \mathrm{L}^{-1}$ de $\mathrm{K}, 11,8 \mathrm{mg} \mathrm{L}^{-1}$ de Ca e 2,24 $\mathrm{mg} \mathrm{L}^{-1}$ de $\mathrm{Mg}$ no cerrado. No sistema agroflorestal, os valores obtidos foram $1,72 \mathrm{mg} \mathrm{L}^{-1}$ de $\mathrm{N}, 1,34 \mathrm{mg}$ $\mathrm{L}^{-1}$ de $\mathrm{P}, 3,98 \mathrm{mg} \mathrm{L}^{-1}$ de $\mathrm{K}, 23,3 \mathrm{mg} \mathrm{L}^{-1}$ de Ca e 2,99 $\mathrm{mg} \mathrm{L}^{-1}$ de $\mathrm{Mg}$ (Tabela 17).

Tabela 17. Concentração de nutrientes $\left(\mathrm{mg} \mathrm{L}^{-1}\right)$ na lixiviação.

\begin{tabular}{lcccccc}
\hline & \multicolumn{3}{c}{ Cerrado } & \multicolumn{3}{c}{ Sistema agroflorestal } \\
\cline { 2 - 6 } Nutrientes & Inverno & Verão & Média & Inverno & Verão & Média \\
\hline $\mathrm{N}$ & 1,22 & 2,40 & 2,26 & 1,34 & 1,78 & 1,72 \\
$\mathrm{P}$ & 0,73 & 0,49 & 0,52 & 0,82 & 1,42 & 1,34 \\
$\mathrm{~K}$ & 0,78 & 1,41 & 1,33 & 0,78 & 4,45 & 3,98 \\
$\mathrm{Ca}$ & 14,89 & 11,36 & 11,78 & 36,72 & 21,29 & 23,26 \\
$\mathrm{Mg}$ & 2,92 & 2,15 & 2,24 & 2,79 & 3,03 & 2,99 \\
\hline
\end{tabular}

A perda de nutrientes pela lixiviação no cerrado foi de $4,73 \mathrm{~kg} \mathrm{ha}^{-1}$ de $\mathrm{N}, 1,09 \mathrm{~kg} \mathrm{ha}^{-1}$ de P, 2,79 $\mathrm{kg} \mathrm{ha}^{-1}$ de $\mathrm{K}, 24,66 \mathrm{~kg} \mathrm{ha}^{-1}$ de Ca e 4,69 $\mathrm{kg} \mathrm{ha}^{-1}$ de $\mathrm{Mg}$. No sistema agroflorestal atingiu 2,56 $\mathrm{kg} \mathrm{ha}^{-1}$ de $\mathrm{N}, 2,00 \mathrm{~kg} \mathrm{ha}^{-1}$ de $\mathrm{P}, 5,92 \mathrm{~kg} \mathrm{ha}^{-1} \mathrm{de} \mathrm{K}$, $34,58 \mathrm{~kg} \mathrm{ha}^{-1}$ de Ca e $4,46 \mathrm{~kg} \mathrm{ha}^{-1}$ de Mg (Tabela 18). A diferença somente foi significativa para o $\mathrm{N}$ no cerrado, com maior perda devido à maior altura percolada.

Esses valores devem ser interpretados com cautela, pois o solo adicionado ao lisímetro foi destorroado, alterando sua estrutura e, consequentemente, a velocidade de percolação e o equilíbrio dos nutrientes na solução. Além disso, não teve a presença das raizes das plantas, como no solo natural.

As perdas de nutrientes por lixiviação em solos tropicais pobres em nutrientes não tem sido altas. $\mathrm{O}$ estudo com oxissolos cultivados e recebendo adubação, revelou que as perdas anuais de $\mathrm{P}$ e $\mathrm{Mg}$ foram inferiores a $1,6 \mathrm{~kg} \mathrm{ha}^{-1}$. Para o $\mathrm{N}, \mathrm{K} \mathrm{e} \mathrm{Ca}$, os totais atingiram 7, 36 e $32 \mathrm{~kg} \mathrm{ha}^{-1}$, respectivamente (Lal, 1980). Para o nitrogênio, a lixiviação em solos africanos, em precipitaçðes médias de $1000 \mathrm{~mm} \mathrm{ano}{ }^{-1}$, e com aplicação de até $300 \mathrm{~kg} \mathrm{ha}^{-1}$ de $\mathrm{N}$, tem sido em torno de 6 a $30 \mathrm{~kg} \mathrm{ha}^{-1}$ (Greenland, 1980). 
Tabela 18. Perdas mensais de água (mm) e nutrientes $\left(\mathrm{kg} \mathrm{ha}^{-1}\right)$ por lixiviação.

\begin{tabular}{ccccccc}
\hline Mês & Altura (mm) & N & $\mathbf{P}$ & K & Ca & Mg \\
\hline \multicolumn{7}{c}{ Cerrado } \\
\hline Out & 19,46 & 0,24 & 0,14 & 0,15 & 2,90 & 0,57 \\
Nov & 5,65 & 0,07 & 0,04 & 0,04 & 0,84 & 0,16 \\
Dez & 41,70 & 1,00 & 0,20 & 0,59 & 4,74 & 0,90 \\
Jan & 15,38 & 0,37 & 0,08 & 0,22 & 1,75 & 0,33 \\
Fev & 42,61 & 1,02 & 0,21 & 0,60 & 4,84 & 0,92 \\
Mar & $\mathbf{8 4 , 4 9}$ & 2,03 & 0,41 & 1,19 & 9,60 & 1,82 \\
\hline SOMA & $\mathbf{2 0 9 , 2 9}$ & $\mathbf{4 , 7 3}$ & $\mathbf{1 , 0 9}$ & $\mathbf{2 , 7 9}$ & $\mathbf{2 4 , 6 6}$ & $\mathbf{4 , 6 9}$ \\
\hline & & Sistema agroflorestal & & \\
\hline Out & 14,56 & 0,20 & 0,12 & 0,11 & 5,35 & 0,41 \\
Nov & 4,41 & 0,06 & 0,04 & 0,03 & 1,62 & 0,12 \\
Dez & 51,41 & 0,92 & 0,73 & 2,29 & 10,94 & 1,56 \\
Jan & 8,23 & 0,15 & 0,12 & 0,37 & 1,75 & 0,25 \\
Fev & 21,95 & 0,39 & 0,31 & 0,98 & 4,67 & 0,67 \\
Mar & 48,11 & 0,86 & 0,68 & 2,14 & 10,24 & 1,46 \\
\hline SOMA & $\mathbf{1 4 8 , 6 7}$ & $\mathbf{2 , 5 6}$ & $\mathbf{2 , 0 0}$ & $\mathbf{5 , 9 2}$ & $\mathbf{3 4 , 5 8}$ & $\mathbf{4 , 4 6}$ \\
\hline
\end{tabular}

Nota-se que esse componente é influenciado pelo tipo de solo, clima e pela presença da vegetação. Em condições de solos ricos em nutrientes, a lixiviação pode representar uma perda significativa. Em uma Terra Roxa Estruturada eutrófica coberta com mata nativa, a perda anual foi de $297 \mathrm{~kg} \mathrm{ha}^{-1} \mathrm{de} \mathrm{N}, 1,4 \mathrm{~kg} \mathrm{ha}^{-1}$ de $\mathrm{P}, 50 \mathrm{~kg}$ $\mathrm{ha}^{-1}$ de K, $277 \mathrm{~kg} \mathrm{ha}^{-1}$ de Ca e $78 \mathrm{~kg} \mathrm{ha}^{-1}$ de $\mathrm{Mg}$ (Santos \& Rodrigues, 1992).

Um trabalho desenvolvido na Costa Rica, comparou a lixiviação em um monocultivo de milho, com um sistema agroflorestal com bananeira e cacaueiro. Obteve-se perdas individuais dos nutrientes inferiores a $3 \mathrm{~kg} \mathrm{ha}^{-1}$, atribuídas à presença das plantas perenes e à imobilização microbiana. No monocultivo, as perdas mais evidentes foram o N, Mg e Ca, com 57,43 e $21 \mathrm{~kg} \mathrm{ha}^{-1}$, respectivamente (Seyfried \& Rao, 1991). 
Outro comportamento referente a lixiviação é a movimentação diferenciada da solução e dos nutrientes, ao longo da frente de percolação. Observou-se, especialmente para o nitrato, movimento mais lento do que o da água. Justificou-se devido a descida rápida da água pelos poros grandes, não havendo equilíbrio significativo com os eletrólitos nos poros finos (Van Noordwijk et al., 1991).

\subsection{Componentes vegetais.}

As plantas estão intimamente relacionadas com a dinâmica dos nutrientes nos ecossistemas. Durante o seu crescimento, absorvem os nutrientes, que são convertidos em biomassa. Participam da reciclagem interna no sistema, pela serapilheira ou através da poda como é feito no cultivo em aléias.

\subsubsection{Serapilheira.}

A fitomassa total produzida anualmente atingiu $2176 \mathrm{~kg} \mathrm{ha}^{-1}$ no cerrado e $2398 \mathrm{~kg} \mathrm{ha}^{-1}$ na leucena. Desse total, a produção acumulada no sistema agroflorestal durante o verão foi significativamente superior à do cerrado.

A produção mensal de serapilheira comportou-se de maneira distinta nas duas áreas, sendo mais uniforme ao longo do ano no cerrado, com concentração em agosto e setembro. Nestes meses, acumulou-se $766 \mathrm{~kg} \mathrm{ha}^{-1}$, correspondendo a $35 \%$ do total anual (Figura 7). Isso coincidiu com o periodo de seca. As plantas ai adaptadas perdem parte das folhas nessa época, retornando ao pleno crescimento vegetativo no início da estação chuvosa (outubro).

Em trabalho anterior, realizado no cerrado em Goiânia, também foi observada maior queda de folhas no período seco, tendo um pico em setembro (Rizzo et al., 1971). No cerrado em Mogi-Guaçú, SP, coletou-se $2990 \mathrm{~kg} \mathrm{ha}^{-1}$ de serapilheira ao ano, sendo o período de abril a junho o mais produtivo (Pompéia, 1989).

A produção de serapilheira varia especialmente em função da densidade da cobertura vegetal. Um estudo comparativo de diversas formações vegetais da região tropical, demonstrou que a fitomassa anual produzida varia de $2,0 \mathrm{t} \mathrm{ha}^{-1} \mathrm{em}$ savanas até 12,6 t ha ${ }^{-1} \mathrm{em}$ florestas (Vitousek, 1984). Para a região de cerrado em 
Brasília, DF, verificou-se a mesma tendência. Produziu-se anualmente $7,8 \mathrm{t} \mathrm{ha}^{-1}$ de serapilheira no cerradão e 2,1 t ha $^{-1}$ no cerrado (Peres et al., 1983).

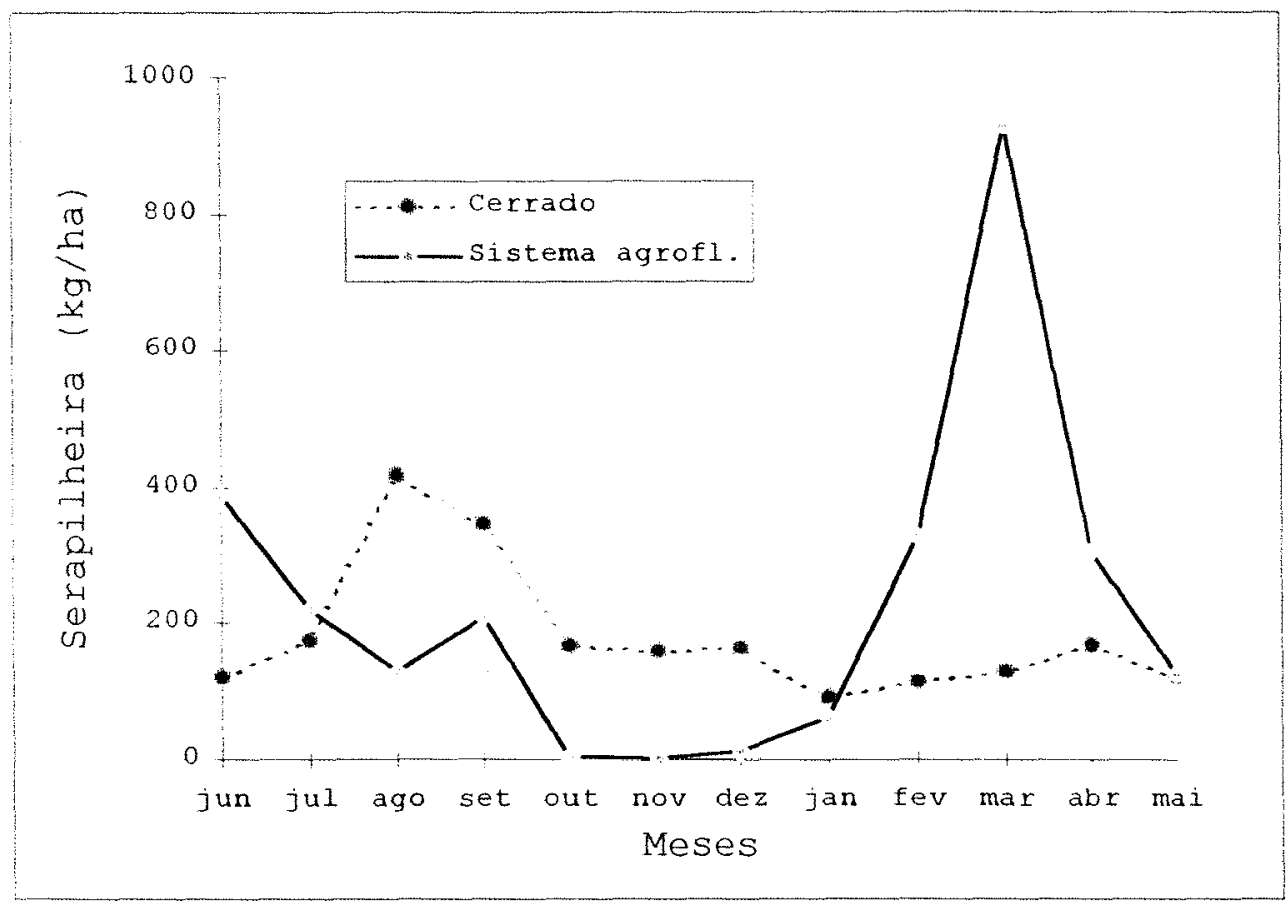

Figura 7. Produção mensal de serapilheira.

A maior produção de serapilheira no sistema agroflorestal ocorreu em março, coincidindo com a fase de reprodução da leucena. $O$ acúmulo de serapilheira da leucena foi baixo no período após a poda (outubro a janeiro), pois estava com intenso crescimento vegetativo. Observou-se também maior produção perto dos renques, atingindo $4897 \mathrm{~kg} \mathrm{ha}^{-1}$ a $0,85 \mathrm{~m}$ da leucena e somente $609 \mathrm{~kg} \mathrm{ha}^{-1}$ no meio da faixa de cultivo (Figura 8).

A serapilheira é uma forma importante de reciclagem da matéria orgânica e dos nutrientes. O estudo em uma área de reflorestamento com leucena, de 2 anos de idade na Índia, demonstrou uma produção anual de $10 \mathrm{t} \mathrm{ha}^{-1}$ de fitomassa seca. Observou-se também, sua decomposição acelerada, restando somente $20 \%$ do $\mathrm{N}$ na fitomassa indecomposta, após 1 ano (Sandhu et al., 1990). 


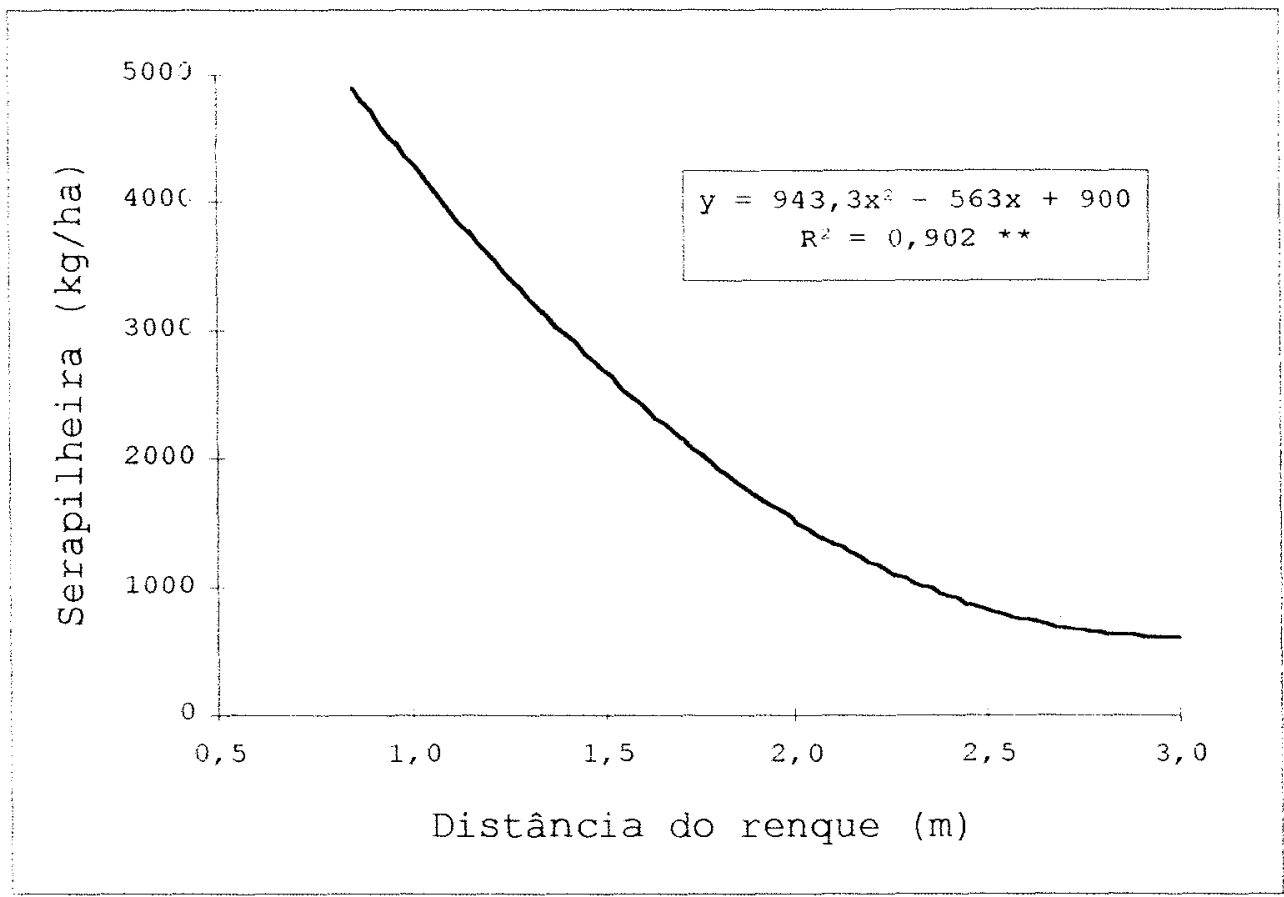

Figura 8. Produção de serapilheira da leucena conforme a distância dos renques.

A concentração média de nutrientes na serapilheira foi de $12,9 \mathrm{~g} \mathrm{~kg}^{-1}$ de $\mathrm{N} ; 0,52 \mathrm{~g} \mathrm{~kg}^{-1}$ de P; 3,41 $\mathrm{g} \mathrm{kg}^{-1}$ de $\mathrm{K} ; 6,28 \mathrm{~g} \mathrm{~kg}^{-1}$ de Ca e 1,72 $\mathrm{g} \mathrm{kg}^{-1}$ de $\mathrm{Mg}$ no cerrado. No sistema agroflorestal, os teores atingiram $22,8 \mathrm{~g} \mathrm{~kg}^{-1}$ de $\mathrm{N} ; 1,28 \mathrm{~g} \mathrm{~kg}^{-1} \mathrm{de} P$; $5,52 \mathrm{~g} \mathrm{~kg}^{-1}$ de K; 15,9 $\mathrm{g} \mathrm{kg}^{-1}$ de Ca e 5,38 $\mathrm{g} \mathrm{kg}^{-1}$ de Mg (Tabela 19).

Tabela 19. Concentração de nutrientes $\left(\mathrm{g} \mathrm{kg}^{-1}\right)$ na serapilheira.

\section{Cerrado Sistema agroflorestal}

\begin{tabular}{lcccccc}
\cline { 2 - 7 } Nutriente & Inverno $^{(1)}$ & Verão $^{(1)}$ & Média $^{(2)}$ & Inverno $^{(1)}$ & Verão $^{(1)}$ & Média $^{(2)}$ \\
\hline $\mathrm{N}$ & $12,59 * *$ & $13,28^{* *}$ & $12,94 \pm 1,38$ & $25,77^{* *}$ & $19,78^{* *}$ & $22,78 \pm 1,15$ \\
$\mathrm{P}$ & $0,67 * *$ & $0,36 * *$ & $0,52 \pm 0,20$ & $1,77^{* *}$ & $0,78 * *$ & $1,28 \pm 0,17$ \\
$\mathrm{~K}$ & $3,01 * *$ & 3,80 & $3,41 \pm 0,66$ & $6,41 * *$ & 4,62 & $5,52 \pm 0,92$ \\
$\mathrm{Ca}$ & $7,40 * *$ & $5,10^{* *}$ & $6,28 \pm 1,13$ & $14,81 * *$ & $16,93 * *$ & $15,87 \pm 1,32$ \\
$\mathrm{Mg}$ & $1,68 * *$ & $1,75^{* *}$ & $1,72 \pm 0,24$ & $4,22 * *$ & $6,54 * *$ & $5,38 \pm 0,32$
\end{tabular}

1. ${ }^{* *}$ significativo $(\alpha=0,01) ; 2$. Média \pm Intervalo de confiança a $5 \%$. 
Os teores de nutrientes na serapilheira do sistema agroflorestal foram superiores aos do cerrado, exceto para o K no verão. No cerrado, a serapilheira era mais fibrosa e pobre em nutrientes, tornando o material mais resistente à decomposição. Isso é vantajoso, pois protege o solo da erosão. Em estudo no cerrado da região de Corumbataí, SP, obteve-se uma taxa de decomposição anual da serapilheira de 34 a 38 $\%$ ao ano (Santos \& Rodrigues, 1982).

As quantidades de nutrientes adicionadas anualmente no cerrado pela serapilheira foram de $27,84 \mathrm{~kg} \mathrm{ha}^{-1}$ de $\mathrm{N} ; 1,08 \mathrm{~kg} \mathrm{ha}^{-1}$ de $\mathrm{P} ; 7,17 \mathrm{~kg} \mathrm{ha}^{-1}$ de $\mathrm{K} ; 13,23 \mathrm{~kg}$ ha ${ }^{-1}$ de Ca e 3,65 $\mathrm{kg} \mathrm{ha}^{-1}$ de Mg (Tabela 20).

Tabela 20. Fitomassa seca e nutrientes adicionados $\left(\mathrm{kg} \mathrm{ha}^{-1}\right)$ pela serapilheira.

\begin{tabular}{lcccccc}
\hline \multirow{2}{*}{ Atributo } & \multicolumn{3}{c}{ Cerrado $^{(1)}$} & \multicolumn{3}{c}{ Sistema agroflorestal } \\
\cline { 2 - 7 } Matéria seca & Inverno & Verão & Total & Inverno & Verão & Total \\
$\mathrm{N}$ & 1228,9 & $947,3 * *$ & 2176,2 & 884,3 & $1513,5 * *$ & 2397,8 \\
$\mathrm{P}$ & 15,15 & 12,69 & $27,84 *$ & 23,36 & $29,97 * *$ & $52,33 *$ \\
$\mathrm{~K}$ & $0,71 *$ & 0,37 & $1,08 * *$ & $1,48 *$ & $1,20 * *$ & $2,68 * *$ \\
$\mathrm{Ca}$ & 3,16 & 4,01 & 7,17 & 5,97 & 6,77 & 12,74 \\
$\mathrm{Mg}$ & 8,31 & 4,92 & $13,23 * *$ & 13,41 & $26,94 * *$ & $40,35 * *$ \\
\hline $\mathrm{l} *$ = significativo com $95 \%$ de confiança; $*$ significativo com $99 \%$ de confiança.
\end{tabular}

A leucena, apesar de ocorrer em menor densidade de plantas em relação ao cerrado, adicionou pela serapilheira $52,3 \mathrm{~kg} \mathrm{ha}^{-1}$ de $\mathrm{N} ; 2,68 \mathrm{~kg} \mathrm{ha}^{-1}$ de P; $12,74 \mathrm{~kg} \mathrm{ha}^{-1}$ de K; $40,35 \mathrm{~kg} \mathrm{ha}^{-1}$ de Ca e 14,18 $\mathrm{kg} \mathrm{ha}^{-1}$ de $\mathrm{Mg}$.

A leucena contribuiu significativamente com maior quantidade de $\mathrm{N}$, $\mathrm{P}, \mathrm{Ca}$ e $\mathrm{Mg}$, em relação ao cerrado. Isso se deveu à maior concentração, que foi aproximadamente o dobro para todos os nutrientes.

A adição de nutrientes pela serapilheira no cerrado varia conforme as condições edafoclimáticas e com a densidade vegetal. Em Mogi-Guaçú, SP, sob cerrado, o aporte anual foi de $43,7 \mathrm{~kg} \mathrm{ha}^{-1}$ de N, 1,5 $\mathrm{kg} \mathrm{ha}^{-1}$ de P, 6,3 $\mathrm{kg} \mathrm{ha}^{-1} \mathrm{de} \mathrm{K}, 24,8 \mathrm{~kg} \mathrm{ha}^{-1}$ de 
Ca e $5,7 \mathrm{~kg} \mathrm{ha}^{-1}$ de $\mathrm{Mg}$ (Pompéia, 1989). Para um cerrado em Brasília, obteve-se uma adição de $17,8 \mathrm{~kg} \mathrm{ha}^{-1}$ de $\mathrm{N}, 1,3 \mathrm{~kg} \mathrm{ha}^{-1}$ de $\mathrm{P}, 3,3 \mathrm{~kg} \mathrm{ha}^{-1}$ de $\mathrm{K}, 6,7 \mathrm{~kg} \mathrm{ha}^{-1}$ de Ca e 2,5 $\mathrm{kg}$ ha $^{-1}$ de $\mathrm{Mg}$ (Peres et al., 1983).

\subsection{2 - Fitomassa da poda.}

A produção total de matéria seca, em 2 anos, foi de $8932 \mathrm{~kg} \mathrm{ha}^{-1}$, sendo $2781 \mathrm{~kg} \mathrm{ha}^{-1}$ de folhas $6150 \mathrm{~kg} \mathrm{ha}^{-1}$ de ramos. Tais valores foram relativamente altos se for considerada a baixa fertilidade do solo. $O$ predominio dos ramos na fitomassa podada esteve relacionado ao porte das plantas, que tinham em média 3 a $4 \mathrm{~m}$ de altura e $5,5 \mathrm{~cm}$ de diâmetro de caule a $60 \mathrm{~cm}$ do solo.

A concentração de nutrientes foi diferenciada conforme a parte da planta. As folhas foram o material mais rico com $33,58 \mathrm{~g} \mathrm{~kg}^{-1} \mathrm{de} \mathrm{N}, 2,10 \mathrm{~g} \mathrm{~kg}^{-1}$ de P, $11,61 \mathrm{~g} \mathrm{~kg}^{-1}$ de $\mathrm{K}, 11,23 \mathrm{~g} \mathrm{~kg}^{-1}$ de Ca e 4,67 $\mathrm{g} \mathrm{kg}^{-1}$ de $\mathrm{Mg}$. Os ramos continham 5,19 $\mathrm{g}$ $\mathrm{kg}^{-1}$ de $\mathrm{N}, 0,36 \mathrm{~g} \mathrm{~kg}^{-1}$ de P, 2,41 $\mathrm{g} \mathrm{kg}^{-1}$ de $\mathrm{K}, 2,79 \mathrm{~g} \mathrm{~kg}^{-1}$ de Ca e $0,81 \mathrm{~g} \mathrm{~kg}^{-1}$ de $\mathrm{Mg}$ (Tabela 21).

Tabela 21. Concentração de nutrientes $\left(\mathrm{g} \mathrm{kg}^{-1}\right)$ nas folhas e ramos da leucena.

\begin{tabular}{lccc}
\hline Nutriente $^{(1)}$ & Folhas & Ramos & Ramos + Folhas \\
\hline $\mathrm{N}$ & $33,58 \pm 3,81$ & $5,19 \pm 0,90$ & $14,98 \pm 2,99$ \\
$\mathrm{P}$ & $2,10 \pm 0,42$ & $0,36 \pm 0,14$ & $0,95 \pm 0,20$ \\
$\mathrm{~K}$ & $11,61 \pm 3,22$ & $2,41 \pm 0,58$ & $5,75 \pm 1,86$ \\
$\mathrm{Ca}$ & $11,23 \pm 2,22$ & $2,79 \pm 0,48$ & $5,72 \pm 1,17$ \\
$\mathrm{Mg}$ & $4,67 \pm 1,01$ & $0,81 \pm 0,34$ & $2,04 \pm 0,37$ \\
\hline
\end{tabular}

1. Médias \pm intervalo de confiança com $95 \%$ de confiança.

Esses teores foram semelhantes aos relatados na literatura, variando de 28,8 a $34,8 \mathrm{~g} \mathrm{~kg}^{-1}$ de N, 1,1 a 1,5 $\mathrm{g} \mathrm{kg}^{-1}$ de P, 13,8 a 20,5 $\mathrm{g} \mathrm{kg}^{-1}$ de $\mathrm{K}, 6,7$ a $26,5 \mathrm{~g} \mathrm{~kg}^{-1} \mathrm{de}$ Ca e 2,8 a 4,6 $\mathrm{g} \mathrm{kg}^{-1}$ de $\mathrm{Mg}$ (Lulandala \& Hall, 1990; Nyathi \& Campbell, 1994).

Os teores de carbono orgânico e micronutrientes também diferiram para as partes da planta. Os ramos foram mais ricos em $\mathrm{Cu}, \mathrm{Zn}$ e $\mathrm{Fe}$, com teores de 22, 
215 e $86 \mathrm{mg} \mathrm{kg}^{-1}$, respectivamente. As folhas tiveram mais $\mathrm{Mn}$, com $38 \mathrm{mg} \mathrm{kg}^{-1}$. O carbono orgânico esteve na concentração de $449 \mathrm{~g} \mathrm{~kg}^{-1}$ (Tabela 22).

Tabela 22. Concentração carbono orgânico $\left(\mathrm{g} \mathrm{kg}^{-1}\right) \mathrm{e}$ micronutrientes $\left(\mathrm{mg} \mathrm{kg}^{-1}\right)$ nas folhas e ramos da leucena (médias de 3 repetições).

\begin{tabular}{lccccc}
\hline Parte analisada & C org. & Cu & Mn & Zn & Fe \\
\hline Ramos & 415 & 22 & 19 & 215 & 86 \\
Folhas & 483 & 15 & 38 & 22 & 56 \\
\hline
\end{tabular}

$\mathrm{O}$ aporte total de nutrientes foi de $125,0 \mathrm{~kg} \mathrm{ha}^{-1}$ de $\mathrm{N} ; 7,57 \mathrm{~kg} \mathrm{ha}^{-1}$ de P; 45,23 $\mathrm{kg} \mathrm{ha}^{-1}$ de $\mathrm{K} ; 47,76 \mathrm{~kg} \mathrm{ha}^{-1}$ de Ca e 17,16 $\mathrm{kg} \mathrm{ha}^{-1}$ de Mg (Tabela 23). Tais quantidades foram relativamente altas em comparação à exigência das culturas agrícolas, exceto para o caso do P e Mg.

Tabela 23. Fitomassa seca e aporte de nutrientes ( $\left.\mathrm{g} \mathrm{ha}^{-1}\right)$ da leucena.

\begin{tabular}{lccc}
\hline Atributo $^{(1)}$ & Folhas & Ramos & Total \\
\hline Matéria seca & $2781 \pm 776$ & $6149 \pm 3.369$ & $8930 \pm 3.835$ \\
$\mathrm{~N}$ & $94,60 \pm 29,71$ & $30,41 \pm 16,42$ & $125,01 \pm 40,6$ \\
$\mathrm{P}$ & $5,41 \pm 1,15$ & $2,16 \pm 1,40$ & $7,57 \pm 2,3$ \\
$\mathrm{~K}$ & $30,50 \pm 8,40$ & $14,73 \pm 10,54$ & $45,23 \pm 15,1$ \\
$\mathrm{Ca}$ & $31,71 \pm 10,42$ & $16,05 \pm 8,02$ & $47,76 \pm 15,6$ \\
$\mathrm{Mg}$ & $12,85 \pm 4,23$ & $4,31 \pm 2,34$ & $17,16 \pm 5,7$ \\
\hline
\end{tabular}

1. Médias \pm intervalo de confiança com $95 \%$ de confiança.

Notou-se, também, adição diferenciada de nutrientes, conforme a parte da planta. As folhas contribuíram com $31 \%$ da matéria seca total, mas, forneceram 76 $\%$ do N; $73 \%$ do P; $67 \%$ do K; $63 \%$ do Ca e $75 \%$ do Mg. Além disso, os nutrientes presentes nos ramos têm baixa disponibilidade, pela lenta decomposição desse material.

Normalmente a relação de ramos e folhas da fitomassa é aumentada com práticas de manejo que permitem o crescimento vegetativo, como podas pouco frequentes. Em um experimento no Havai, com duas cultivares de leucena plantadas em 
monocultivo, verificou-se menor produção de fitomassa nos cortes mais frequentes. Porém, a proporção de folhas e ramos era menor. O espaçamento entre plantas na linha não teve efeito significativo nessa relação (Guevarra et al., 1978; Ferraris, 1979). Na Indonésia, o uso de podas menos frequentes manteve constante a produção de folhas da leucena, mas houve aumento significativo do crescimento dos ramos (Catchpoole $\&$ Blair, 1990).

Em outro trabalho com leucena em cultivo em aléias, na Nigéria, obteve-se maior produção de fitomassa e acúmulo de $\mathrm{N}$ em intervalo de cortes semestral, em relação aos cortes mensais. Apesar desse aumento, a fitomassa tornou-se mais lenhosa (mais ramos), observando nos brotos novos (podas mensais), maior concentração de nitrogênio. Nos cortes mais frequentes, apesar do menor aporte de fitomassa e $\mathrm{N}$, a produção das culturas associadas (milho e feijão miúdo) aumentou. Isso ocorreu em função da menor competição exercida pela leucena (Duguma et al., 1988). Em virtude desses resultados, espera-se liberação mais rápida de nutrientes para as culturas intercalares em manejos agrossilvoculturais que favorecem o desenvolvimento de folhas.

Essa proporção é modificada ainda, conforme a idade da planta. Um trabalho com Leucaena leucocephala PR, com densidade de plantio de 2500 plantas ha ${ }^{-1}$ e com poda somente no $5^{\circ}$ ano após o plantio, mostrou uma proporção de folhas de 22 $\%$ da matéria seca total (Wang et al., 1991).

\subsubsection{Produção das culturas.}

A adubação verde do milho consorciado com leguminosas produziu $5486 \mathrm{~kg} \mathrm{ha}^{-1}$ de fitomassa seca. Com centeio e aveia, obteve-se $923 \mathrm{~kg} \mathrm{ha}^{-1}$. Foram ainda incorporados ao solo, os resíduos culturais do feijão e do milho, que contribuíram com 438 e $2812 \mathrm{~kg} \mathrm{ha}^{-1}$, respectivamente (Tabela 24). A baixa produção de fitomassa do centeio e aveia foi ocasionada pela falta de água durante a estação de crescimento.

A adição total de fitomassa foi de $9659 \mathrm{~kg} \mathrm{ha}^{-1}$, contribuindo significativamente com a reciclagem de nutrientes. Essa produção foi relativamente alta, considerando a baixa fertilidade do solo. 
Tabela 24. Fitomassa seca e nutrientes $\left(\mathrm{kg} \mathrm{ha}^{-\mathrm{I}}\right)$ adicionados pelas culturas.

\begin{tabular}{|c|c|c|c|c|c|}
\hline & \multicolumn{2}{|c|}{ Adubos verdes } & \multicolumn{2}{|c|}{ Restos culturais } & \multirow[b]{2}{*}{ Total } \\
\hline Atributo $^{(I)}$ & Milho + leg. & Cent. + aveia & Feijão & Milho & \\
\hline Massa seca & $5486 \pm 975$ & $923 \pm 149$ & $438 \pm 43$ & $2812 \pm 472$ & 9659 \\
\hline $\mathrm{N}$ & $89,67 \pm 20,67$ & $11,58 \pm 2,99$ & $6,94 \pm 1,02$ & $15,72 \pm 2,67$ & 123,91 \\
\hline$P$ & $8,10 \pm 2,66$ & $0,96 \pm 0,24$ & $0,54 \pm 0,24$ & $1,41 \pm 0,48$ & 11,01 \\
\hline K & $44,60 \pm 8,91$ & $9,16 \pm 2,29$ & $5,70 \pm 0,90$ & $19,79 \pm 4,40$ & 79,25 \\
\hline $\mathrm{Ca}$ & $37,48 \pm 8,94$ & $2,58 \pm 0,88$ & $4,63 \pm 0,92$ & $3,73 \pm 0,74$ & 48,42 \\
\hline $\mathrm{Mg}$ & $19,79 \pm 4,05$ & $1,11 \pm 0,17$ & $2,60 \pm 0,42$ & $4,58 \pm 1,26$ & 28,08 \\
\hline
\end{tabular}

1. Médias \pm intervalo de confiança $(95 \%)$.

$\mathrm{O}$ aporte total de nutrientes pelas culturas foi de $123,9 \mathrm{~kg} \mathrm{ha}^{-1} \mathrm{de} \mathrm{N}$; $11,01 \mathrm{~kg} \mathrm{ha}^{-1}$ de P; 79,25 $\mathrm{kg} \mathrm{ha}^{-1}$ de $\mathrm{K} ; 48,42 \mathrm{~kg} \mathrm{ha}^{-1}$ de Ca e 28,08 $\mathrm{kg} \mathrm{ha}^{-1}$ de Mg. A maior adição foi obtida com o milho + leguminosa, em virtude da maior fitomassa. Esta cultura teve um ciclo maior ( 8 meses) e não foi feita a colheita dos grãos.

Os resíduos do milho tiveram baixa concentração de nutrientes na fitomassa com 5,84 $\mathrm{g} \mathrm{kg}^{-1}$ de $\mathrm{N}, 0,51 \mathrm{~g} \mathrm{~kg}^{-1}$ de $\mathrm{P}, 6,82 \mathrm{~g} \mathrm{~kg}^{-1}$ de $\mathrm{K}, 1,32 \mathrm{~g} \mathrm{~kg}^{-1}$ de Ca e $1,55 \mathrm{~g} \mathrm{~kg}^{-1}$ de $\mathrm{Mg}$. $\mathrm{O}$ resíduo de feijão adzuki (leguminosa), apresentou os maiores teores de $\mathrm{Ca}$ e $\mathrm{Mg}$, com 10,36 e 5,93 $\mathrm{g} \mathrm{kg}^{-1}$, respectivamente (Tabela 25).

Tabela 25. Concentração de nutrientes $\left(\mathrm{g} \mathrm{kg}^{-1}\right)$ na fitomassa seca das culturas.

\begin{tabular}{lcccc}
\hline \multirow{2}{*}{ Nutriente $^{(1)}$} & \multicolumn{2}{c}{ Adubos verdes } & \multicolumn{2}{c}{ Restos culturais } \\
\cline { 2 - 5 } & Milho + legum. & Centeio + aveia & Feijão & Milho \\
\hline $\mathrm{N}$ & $16,53 \pm 2,35$ & $12,36 \pm 1,75$ & $15,68 \pm 1,17$ & $5,84 \pm 0,61$ \\
$\mathrm{P}$ & $1,45 \pm 0,29$ & $1,06 \pm 0,21$ & $1,24 \pm 0,52$ & $0,51 \pm 0,14$ \\
$\mathrm{~K}$ & $8,26 \pm 1,12$ & $10,17 \pm 2,38$ & $13,36 \pm 1,85$ & $6,82 \pm 0,84$ \\
$\mathrm{Ca}$ & $6,93 \pm 1,49$ & $2,74 \pm 0,72$ & $10,36 \pm 1,02$ & $1,32 \pm 0,09$ \\
$\mathrm{Mg}$ & $3,67 \pm 0,63$ & $1,22 \pm 0,08$ & $5,93 \pm 0,55$ & $1,55 \pm 0,26$ \\
\hline
\end{tabular}

1. Médias \pm intervalo de confiança $(95 \%)$. 
A produção de grãos no cultivo em aléias foi baixa. Para o feijão adzuki, o rendimento médio (peso seco) foi de $174,9 \mathrm{~kg} \mathrm{ha}^{-1} \pm 20,7 \mathrm{~kg}$ (intervalo de confiança $95 \%$ ). O milho teve rendimento médio de $1210 \mathrm{~kg} \mathrm{ha}^{-1}$.

A produção baixa das culturas anuais foi ocasionada, em parte, pela competição exercida pela leucena. No feijão, observou-se produção de $148,3 \mathrm{~kg} \mathrm{ha}^{-1}$ nas linhas distantes $1,5 \mathrm{~m}$ dos renques, o que foi significativamente menor $(5 \%$ de significância), do que a $2,5 \mathrm{~m}$, onde obteve-se $201,5 \mathrm{~kg} \mathrm{ha}^{-1}$. No milho, a análise de regressão entre a produção e a distância dos renques foi significativa $(P<0,05)$. A $1 \mathrm{~m}$ da leucena, produziu $604 \mathrm{~kg} \mathrm{ha}^{-1}$, aumentando para $1700 \mathrm{~kg} \mathrm{ha}^{-1}$ no centro da faixa de cultivo (Figura 9). Outra causa foi a menor densidade de plantio para o milho, em comparação ao monocultivo, tendo-se apenas 35.000 plantas $\mathrm{ha}^{-1}$.

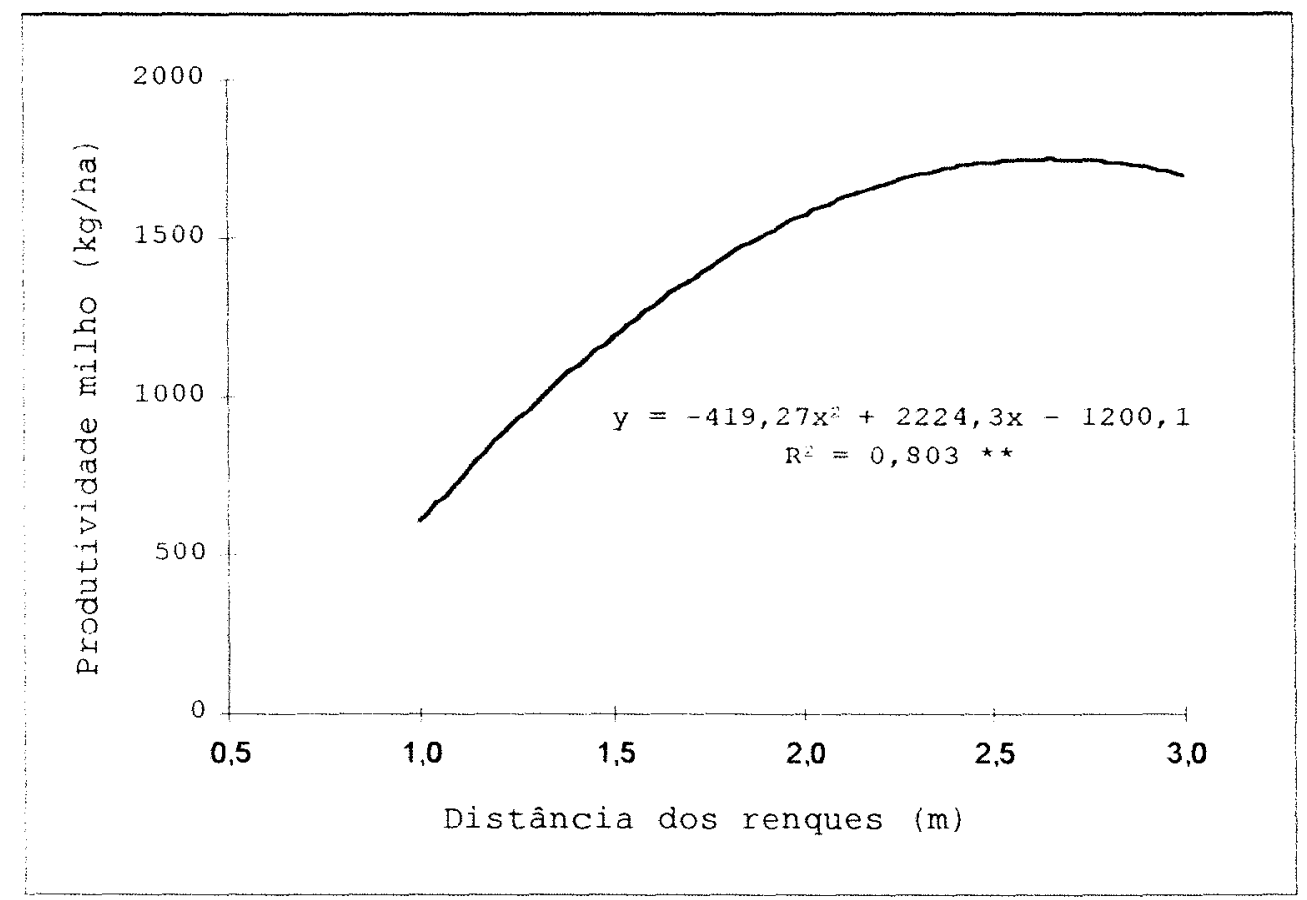

Figura 9. Produtividade do milho conforme a distância dos renques.

A redução do rendimento das culturas no cultivo em aléias foi estudada em diversas condições. Singh et al. (1989) e Fernandes et al. (1993) 
demonstram competição mais severa em solos pobres e com deficiência hídrica. As causas foram a competição por luz, água e nutrientes exercida pela leucena.

Os teores de nutrientes nos grãos variaram de $36,1 \mathrm{~g} \mathrm{~kg}^{-1}$ de $\mathrm{N}$ e $3,43 \mathrm{~g}$ $\mathrm{kg}^{-1}$ de $\mathrm{P}$ para o feijão adzuki e $14,24 \mathrm{~g} \mathrm{~kg}^{-1}$ de $\mathrm{N}$ e $2,29 \mathrm{~g} \mathrm{~kg}^{-1}$ de $\mathrm{P}$, no milho (Tabela 26). A concentração, especialmente de $N$ e $P$ nos grãos, foi alta, removendo $22,7 \mathrm{~kg} \mathrm{ha}^{-1}$ de $\mathrm{N}, 3,27 \mathrm{~kg} \mathrm{ha}^{-1}$ de P, 6,38 $\mathrm{kg} \mathrm{ha}^{-1}$ de $\mathrm{K}, 0,72 \mathrm{~kg} \mathrm{ha}^{-1}$ de Ca e 1,35 $\mathrm{kg} \mathrm{ha}^{-1} \mathrm{de} \mathrm{Mg.}$

Tabela 26. Concentração $\left(\mathrm{g} \mathrm{kg}^{-1}\right)$ e remoção $\left(\mathrm{kg} \mathrm{ha}^{-1}\right)$ de nutrientes nos grãos.

\begin{tabular}{lccccc}
\hline & \multicolumn{2}{c}{ Feijão adzuki } & \multicolumn{2}{c}{ Milho } & \multirow{2}{*}{ Nutriente } \\
\cline { 2 - 5 } & Teor & Remoção $^{(1)}$ & Teor & Remoção $^{(1)}$ & Total \\
\hline $\mathbf{N}$ & 36,06 & $6,15 \pm 0,78$ & 14,24 & $16,53 \pm 2,74$ & 22,68 \\
$\mathbf{P}$ & 3,43 & $0,60 \pm 0,07$ & 2,29 & $2,67 \pm 0,49$ & 3,27 \\
$\mathbf{K}$ & 16,83 & $2,94 \pm 0,34$ & 2,92 & $3,44 \pm 0,69$ & 6,38 \\
Ca & 2,64 & $0,46 \pm 0,06$ & 0,23 & $0,26 \pm 0,04$ & 0,72 \\
My & 1,88 & $0,33 \pm 0,04$ & 0,92 & $1,02 \pm 0,18$ & 1,35 \\
\hline
\end{tabular}

1. Média \pm Intervalo de confiança, com $5 \%$ de significância.

\subsection{Componentes edáficos.}

As alterações nas características químicas do solo são importantes para compreender o efeito do cultivo em aléias sobre a reserva de nutrientes, em comparação à condição original do solo. Observou-se também a perda de $\mathrm{N}$ por volatilização, a partir da aplicação da fitomassa da leucena sobre o solo.

\subsubsection{Nutrientes no solo.}

Os teores de matéria orgânica $(\mathrm{MO}), \mathrm{N}, \mathrm{P}, \mathrm{Ca}$ e $\mathrm{Mg}$, na camada superficial $(0-20 \mathrm{~cm})$, foram maiores no sistema agroflorestal. As concentrações foram de $26,00 \mathrm{~g} \mathrm{~kg}^{-1}, 1,33 \mathrm{~g} \mathrm{~kg}^{-1}, 11,25 \mathrm{mg} \mathrm{kg}^{-1}, 18,63 \mathrm{mmol}_{\mathrm{c}} \mathrm{dm}^{-3}$ e 9,50 $\mathrm{mmol}_{\mathrm{c}} \mathrm{dm}^{-3}$, respectivamente. No cerrado, os teores foram de $18,23 \mathrm{~g} \mathrm{~kg}^{-1}$ de $\mathrm{MO}, 0,90 \mathrm{~g} \mathrm{~kg}^{-1} \mathrm{de} \mathrm{N}$, $4,25 \mathrm{mg} \mathrm{kg}^{-1}$ de P, 2,38 $\mathrm{mmol}_{\mathrm{c}} \mathrm{dm}^{-3}$ de Ca e 1,63 $\mathrm{mmol}_{\mathrm{v}} \mathrm{dm}^{-3}$ de Mg (Tabela 27). 
Tabela 27. Teores de matéria orgânica e nutrientes no solo, na profundidade de $0-20 \mathrm{~cm}$.

\begin{tabular}{lcccccc}
\hline \multirow{2}{*}{ Atributo } & \multicolumn{3}{c}{ Cerrado } & \multicolumn{3}{c}{ Sistema agroflorestal } \\
\cline { 2 - 7 } & Inverno & Verão & Média $^{(1)}$ & Inverno & Verão & Média $^{(1)}$ \\
\hline $\mathrm{MO}\left(\mathrm{g} \mathrm{kg}^{-1}\right)$ & 14,50 & 21,75 & $18,13^{* *}$ & 20,50 & 31,50 & $26,00^{* *}$ \\
$\mathrm{~N}\left(\mathrm{~g} \mathrm{~kg}^{-1}\right)$ & 0,93 & 0,88 & $0,90^{* *}$ & 1,70 & 0,95 & $1,33^{* *}$ \\
$\mathrm{P}\left(\mathrm{mg} \mathrm{kg}^{-1}\right)$ & 3,50 & 5,75 & $4,25 * *$ & 10,00 & 12,50 & $11,25 * *$ \\
$\mathrm{~K}\left(\mathrm{mmol}_{\mathrm{c}} \mathrm{dm}^{-3}\right)$ & 0,68 & 0,53 & 0,60 & 0,45 & 0,58 & 0,51 \\
$\mathrm{Ca}\left(\mathrm{mmol}_{\mathrm{c}} \mathrm{dm}^{-3}\right)$ & 2,50 & 2,25 & $2,38^{* *}$ & 19,50 & 17,75 & $18,63^{* *}$ \\
$\mathrm{Mg}\left(\mathrm{mmol}_{\mathrm{c}} \mathrm{dm}^{-3}\right)$ & 1,00 & 2,25 & $1,63^{* *}$ & 10,50 & $\mathbf{8 , 5 0}$ & $9,50^{* *}$ \\
\hline
\end{tabular}

1. ${ }^{* *}=$ significativo com $99 \%$ de confiança.

Esses resultados, obtidos em amostragens trimestrais, foram similares aos obtidos nas trincheiras. O aumento no teor de carbono orgânico do solo em função do suprimento continuo de fitomassa também foi observado em outros locais. Em Ibadan, Nigéria, o cultivo em aléias em um alfissol, utilizando ('assia sp., resultou em maior teor desse elemento na camada superficial do solo $(0-15 \mathrm{~cm})$, em comparação ao solo original (Yamoah et al., 1986). Neste mesmo local, 6 anos após um cultivo em aléias com leucena, aumentou os teores de C orgânico, N, K e Mg no solo (Lal, 1989c). Contudo, na Costa do Marfim, em 3 anos de cultivo em aléias com Gliricidia sepium, apesar de ter havido enriquecimento em carbono na camada superficial, houve diminuição nos teores de $\mathrm{N}, \mathrm{Mg}$ e $\mathrm{K}$ no subsolo. As causas relatadas foram as perdas por lixiviação, remoção pelas colheitas e imobilização pelas plantas nos renques (Schroth et al., 1995).

O teor de nutrientes no solo sob cultivo em aléias, manteve-se em níveis relativamente constantes ao longo do ano, não havendo alterações significativas, mesmo após a aplicação da fitomassa das culturas e da leucena. Somente o fósforo e a matéria orgânica tiveram ligeiro acréscimo durante o verão. Esse fenômeno também foi relatado por Szott et al., (1991b), justificando-o à baixa quantidade de fitomassa aplicada e à permanência dos elementos em formas orgânicas ou inorgânicas não 
detectáveis pelas técnicas rotineiras de análise. Seria necessário um tempo maior para modificar os niveis de nutrientes no solo.

Por outro lado, o uso de métodos, tais como bolsas com fitomassa e a incubação no solo, em condições controladas, seria mais eficiente no estudo da liberação de nutrientes da fítomassa ao solo, em curto período de tempo (Constantinides \& Fownes, 1994).

A reserva de minerais no solo disponíveis para as plantas na profundidade de $0-160 \mathrm{~cm}$ e considerando a densidade de $1,0 \mathrm{~g} \mathrm{~cm}^{-3}$, seguiu a mesma tendência dos teores de nutrientes. Obteve-se no sistema agroflorestal $17700 \mathrm{~kg} \mathrm{ha}^{-1}$ de $\mathrm{N}, 52,5 \mathrm{~kg} \mathrm{ha}^{-1}$ de $\mathrm{P}, 329 \mathrm{~kg} \mathrm{ha}^{-1}$ de $\mathrm{K}, 1568 \mathrm{~kg} \mathrm{ha}^{-1}$ de Ca e $705 \mathrm{~kg} \mathrm{ha}^{-1}$ de Mg. No cerrado, teve $7400 \mathrm{~kg} \mathrm{ha}^{-1}$ de N, 27,5 kg ha ${ }^{-1}$ de P, $305 \mathrm{~kg} \mathrm{ha}^{-1}$ de K, $376 \mathrm{~kg} \mathrm{ha}^{-1}$ de Ca e $210 \mathrm{~kg} \mathrm{ha}^{-1} \mathrm{de} \mathrm{Mg}$ (Tabela 28).

Tabela 28. Reserva de nutrientes no solo $\left(\mathrm{kg} \mathrm{ha}^{-1}\right)$, na profundidade de $0-160 \mathrm{~cm}$.

\begin{tabular}{lccccc}
\hline Local & N & P & K & Ca & Mg \\
\hline Cerrado & $7400^{* *}$ & $27,5 * *$ & 305 & $376^{* *}$ & $210^{* *}$ \\
Sistema agrollorestal & $17700^{* *}$ & $52,5 * *$ & 329 & $1568^{* *}$ & $705^{* *}$ \\
\hline
\end{tabular}

$1{ }^{* *}=$ significativo com $99 \%$ de confiança.

O sistema agroflorestal apresentou em média, 2,4 vezes mais $\mathrm{N}$ e 1,9 vezes mais $\mathrm{P}$ do que o cerrado. As maiores diferenças ocorreram com o $\mathrm{Ca}$ e $\mathrm{Mg}$, cuja reserva foi de 4,2 e 3,4 vezes superior, respectivamente.

O nutriente com maior reserva foi de nitrogênio. Considerando que este elemento é encontrado predominantemente na forma orgânica e assumindo uma taxa de mineralização entre 1 e $3 \%$, pode-se ter um suprimento razoável às culturas. Contudo, nem sempre há boa correlação entre a quantidade total e a disponibilidade às plantas. Esta é dependente da estabilidade da matéria orgânica, tipo de solo, perdas por erosão e lixiviação, clima e cultura (Cantarella et al., 1992). 
O nutriente com menor reserva no solo foi o fósforo, apresentando $52,5 \mathrm{~kg} \mathrm{ha}^{-1}$ no agroflorestal e $27,5 \mathrm{~kg} \mathrm{ha}^{-1}$ e no cerrado. Provavelmente foi o elemento mais limitante ao crescimento vegetal.

\subsubsection{Volatilização de nitrogênio}

A perda de nitrogênio na forma de amônia, durante o período após a aplicação da fitomassa podada da leucena (150 dias), atingiu $46,67 \mathrm{~kg} \mathrm{ha}^{-1}$ no sistema agroflorestal. Isso foi significativamente maior ( $99 \%$ de confiança) do que o encontrado no cerrado, que totalizou $44,47 \mathrm{~kg} \mathrm{ha}^{-1}$.

Contudo, esses valores absolutos não foram considerados, pois as análises da espuma coletora tratada com ácido, (prova em branco sem exposição no campo), apresentaram teores de amônia variáveis conforme o tempo de reação. Observou-se liberação de $1,43 \mathrm{mg}$ de $\mathrm{N}$ com 12 dias e $0,73 \mathrm{mg}$ de $\mathrm{N}$ com 8 dias de tratamento, o que foi atribuido à decomposição da espuma. Isto poderia ser evitado pelo uso de espumas brancas (

Para contornar esse problema, os valores encontrados no cerrado foram utilizados como brancos, ou seja, indicaram a decomposição média da espuma onde não foi aplicada fitomassa. Consequentemente, a liberação líquida de amônia a partir da leucena foi obtida pela diferença entre o $\mathrm{N}$ volatilizado no sistema agroflorestal e no cerrado. Isso resultou em $2,20 \mathrm{~kg} \mathrm{ha}^{-1}$ de $\mathrm{N}$, equivalendo à $1,8 \%$ do $\mathrm{N}$ total aplicado.

A volatilização depende da quantidade e qualidade da fitomassa. Normalmente em materiais ricos em nitrogênio e menos lignificados, aplicados sobre o solo, pode-se perder até $20 \%$ como amônia (Palm, 1995). Para fitomassa de lentilha, aplicada sobre o solo, perdeu-se $14 \%$ do $\mathrm{N}$ adicionado, havendo maior volatilização na primeira semana de tratamento (Janzen \& McGinn, 1991). Além disso, esse processo é dependente de fatores edáficos e climáticos. Nas condições avaliadas, com $\mathrm{pH}$ ácido e boa drenagem, a volatilização tende a ser inibida. Outro aspecto, foi a elevada proporção de material lenhoso, de decomposição lenta, havendo imobilização do nitrogênio a medida que ia sendo mineralizado. 
As maiores taxas de liberação ocorreram até 80 dias após a aplicação da fitomassa, com máximo em torno de 34 dias (Figura 10). Neste período a perda diária atingiu até $24 \mathrm{~g} \mathrm{ha}^{-1}$ de nitrogênio. A eficiência do coletor variou de 5,4 a $12,0 \%$.

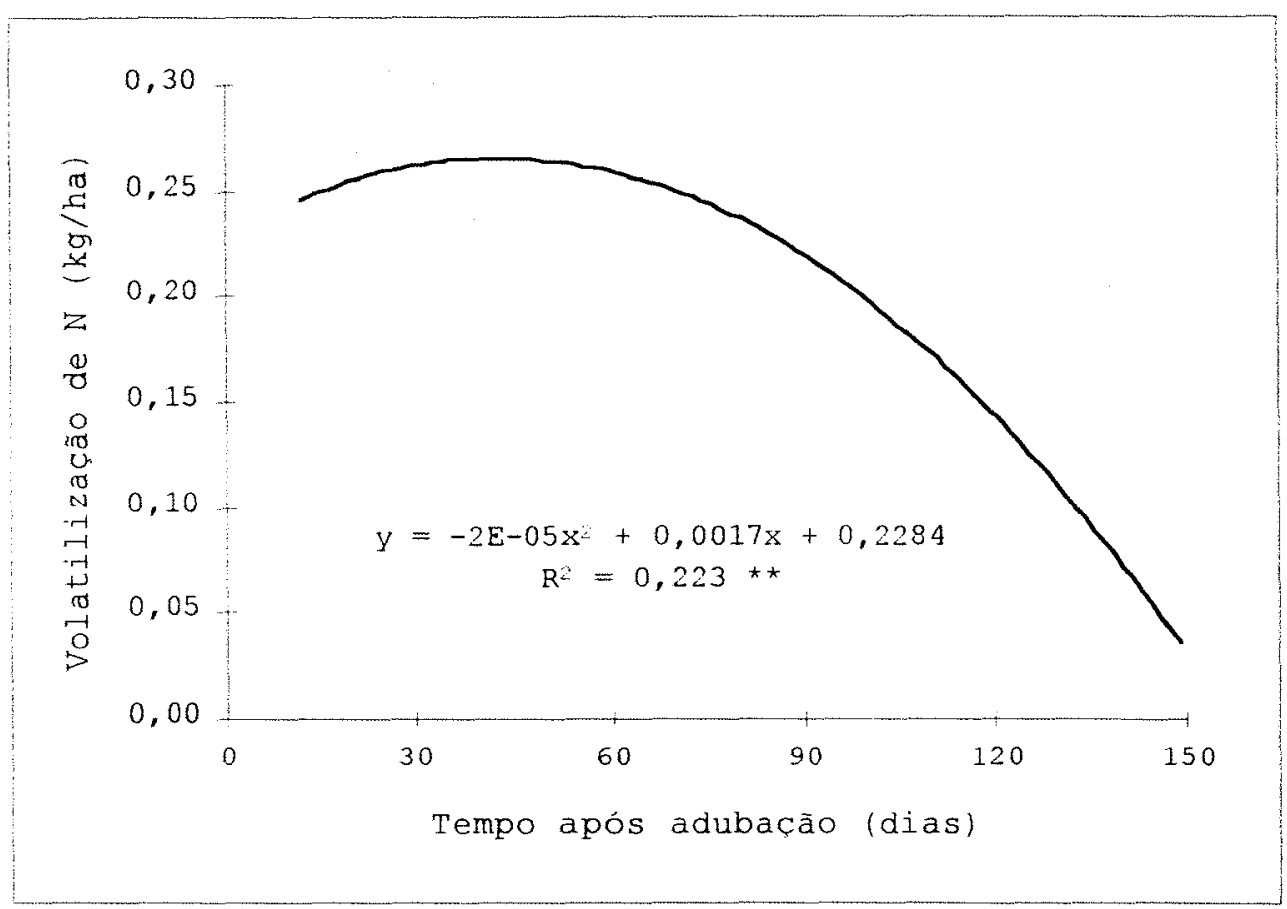

Figura 10. Volatilização de nitrogênio após a aplicação da fitomassa da leucena.

\subsection{Balanço de nutrientes.}

Foi obtido pela diferença entre a entrada externa de nutrientes (precipitação) e as saídas (lixiviação, enxurrada, colheita dos grãos e volatilização). Contabilizou-se ainda a reciclagem interna nos componentes hídricos e vegetais.

A precipitação incidente adicionou anualmente $15,5 \mathrm{~kg}^{-1}$ de $\mathrm{N}, 2,8$ $\mathrm{kg} \mathrm{ha}^{-1}$ de P, 5,4 kg ha ${ }^{-1}$ de $\mathrm{K}, 13,0 \mathrm{~kg} \mathrm{ha}^{-1}$ de Ca e 2,4 $\mathrm{kg} \mathrm{ha}^{-1}$ de Mg (Tabela 29).

As saídas anuais de nutrientes no cerrado totalizaram $6,9 \mathrm{~kg} \mathrm{ha}^{-1} \mathrm{de} \mathrm{N}$, 1,5 $\mathrm{kg} \mathrm{ha}^{-1}$ de $\mathrm{P}, 4,7 \mathrm{~kg} \mathrm{ha}^{-1}$ de $\mathrm{K}, 28,4 \mathrm{~kg} \mathrm{ha}^{-1}$ de Ca e 4,9 $\mathrm{kg} \mathrm{ha}^{-1}$ de $\mathrm{Mg}$. Já no sistema agroflorestal, foram perdidos $28,3 \mathrm{~kg} \mathrm{ha}^{-1}$ de $\mathrm{N}, 5,5 \mathrm{~kg} \mathrm{ha}^{-1}$ de $\mathrm{P}, 13,3 \mathrm{~kg} \mathrm{ha}^{-1}$ de $\mathrm{K}$, $36,2 \mathrm{~kg} \mathrm{ha}^{-1}$ de Ca e 6,1 kg ha ${ }^{-1}$ de $\mathrm{Mg}$. 
Tabela 29. Balanço anual de nutrientes $\left(\mathrm{kg} \mathrm{ha}^{-1}\right)$ no cerrado e sistema agroflorestal.

\begin{tabular}{|c|c|c|c|c|c|}
\hline COMPONENTES $^{(1)}$ & $\mathbf{N}$ & $\mathbf{P}$ & $\mathbf{K}$ & $\mathrm{Ca}$ & $\mathbf{M g}$ \\
\hline \multicolumn{6}{|c|}{ Cerrado } \\
\hline Precipitação (Entrada) & 15,47 & 2,82 & 5,35 & 12,95 & 2,42 \\
\hline Gotejamento de copa & 5,30 & 3,01 & 3,18 & 14,93 & 2,03 \\
\hline Fluxo de caule & $0,23 *$ & 0,21 & $0,51 * *$ & 0,09 & 0,11 \\
\hline Serapilheira & $27,84 *$ & $1,08 * *$ & 7,17 & $13,23 * *$ & $3,65 * *$ \\
\hline Soma do ciclo planta-solo: & 33,37 & 4,30 & 10,86 & 28,25 & 5,79 \\
\hline Erosão & $2,20 *$ & 0,37 & 1,90 & $3,77 *$ & 0,22 \\
\hline Lixiviação & $4,73 *$ & 1,09 & 2,79 & 24,66 & 4,69 \\
\hline Soma das saídas: & 6,93 & 1,46 & 4,69 & 28,43 & 4,91 \\
\hline SALDO: & 8,54 & 1,36 & 0,66 & $-15,49$ & $-2,49$ \\
\hline \multicolumn{6}{|c|}{ Sistema agroflorestal } \\
\hline Precipitação (Entrada) & 15,47 & 2,82 & 5,35 & 12,95 & 2,42 \\
\hline Gotcjamento de copa & 5,20 & 2,91 & 4,74 & 17,77 & 2,84 \\
\hline Fluxo de caule & $0,10^{*}$ & 0,12 & $1,00 * *$ & 0,10 & 0,19 \\
\hline Serapilheira & $52,33 *$ & $2,68 * *$ & 12,74 & $40,35 * *$ & $14,18 * *$ \\
\hline Fitomassa podada & 62,51 & 3,79 & 22,62 & 23,88 & 8,58 \\
\hline Restos de cultura & 34,24 & 2,91 & 34,65 & 10,94 & 8,29 \\
\hline Soma do ciclo planta-solo: & 154,38 & 12,41 & 75,75 & 93,04 & 34,08 \\
\hline Erosão & $0,86 *$ & 0,19 & 0,96 & $0,87^{*}$ & 0,28 \\
\hline Lixiviação & $2,56 *$ & 2,00 & 5,92 & 34,58 & 4,46 \\
\hline Grãos colhidos & 22,68 & 3,27 & 6,38 & 0,72 & 1,35 \\
\hline Volatilização & 2,20 & $\cdots$ & -- & -- & -- \\
\hline Soma das saidas: & 28,30 & 5,46 & 13,26 & 36,17 & 6,09 \\
\hline SALDO: & $-12,83$ & $-2,64$ & $-7,91$ & $-23,25$ & $-3,67$ \\
\hline
\end{tabular}

$1 .{ }^{*}=$ significativo com $95 \%$ de confiança; $* *=$ significativo com $99 \%$ de confiança. 
A lixiviação foi o processo que mais removeu nutrientes catiônicos, contribuindo em 46 a $96 \%$ das perdas. Os grãos foram importantes na saída de $\mathrm{N}$ e P. A enxurrada contribuiu pouco em virtude da cobertura permanente do solo.

As perdas por lixiviação foram superestimadas em função da metodologia empregada. Tais valores resultam da alteração na movimentação da água e no equilíbrio com os solutos, em função da modificação na estrutura do solo dos lisimetros. Nota-se também a importância das raízes das árvores na reciclagem dos minerais, evitando a perda para camadas mais profundas. Isso foi evidenciado por Pompéia (1989), que obteve concentração muito baixa de nutrientes na solução percolada em solo de cerrado vegetado e sem revolvimento.

As perdas de nutrientes no sistema agroflorestal foram maiores em relação ao cerrado, chegando a 3,7 vezes superior para o $P$ e 4,1 vezes para o $\mathrm{N}$, o que esteve relacionado à maior reserva daquele solo e a colheita dos grãos sem reposição na forma de fertilizantes.

A partir desses resultados, obteve-se no cerrado, um saldo anual de nutrientes no solo de $8,54 \mathrm{~kg} \mathrm{ha}^{-1}$ de $\mathrm{N}, 1,36 \mathrm{~kg} \mathrm{ha}^{-1}$ de $\mathrm{P}, 0,66 \mathrm{~kg} \mathrm{ha}^{-1}$ de $\mathrm{K},-15,49 \mathrm{~kg}$ $\mathrm{ha}^{-1}$ de $\mathrm{Ca}$ e $-2,49 \mathrm{~kg} \mathrm{ha}^{-1}$ de $\mathrm{Mg}$. Os valores negativos resultam no empobrecimento contínuo do solo, diminuindo a disponibilidade de nutrientes para a vegetação, uma vez que seus teores eram baixos a muito baixos, exceto para o nitrogênio.

A sobrevivência da vegetação nestas condições está ligada ao armazenamento dos minerais, especialmente no caso do $\mathrm{N}, \mathrm{P}$ e $\mathrm{Ca}$, nos quais a reserva na fitomassa é superior à do solo (Pompéia, 1989).

O saldo anual de nutrientes no cultivo em aléias totalizou $-12,83 \mathrm{~kg}$ ha ${ }^{\prime}$ de N, $-2,64 \mathrm{~kg} \mathrm{ha}^{-1}$ de P, $-7,91 \mathrm{~kg} \mathrm{ha}^{-1}$ de K, $-23,25 \mathrm{~kg} \mathrm{ha}^{-1}$ de Ca e -3,67 $\mathrm{kg} \mathrm{ha}^{-1} \mathrm{de} \mathrm{Mg}$. Foi menor ao cerrado para todos nutrientes em função das maiores perdas.

A reciclagem anual de nutrientes no ciclo planta-solo no cerrado, atingiu 33,4 $\mathrm{kg} \mathrm{ha}^{-1}$ de N, 4,3 $\mathrm{kg} \mathrm{ha}^{-1}$ de P, 10,9 $\mathrm{kg} \mathrm{ha}^{-1}$ de $\mathrm{K}, 28,3 \mathrm{~kg} \mathrm{ha}^{-1}$ de Ca e 5,8 kg $\mathrm{ha}^{-1}$ de $\mathrm{Mg}$. A serapilheira foi a forma mais importante para o $\mathrm{N}, \mathrm{K}$, Ca e $\mathrm{Mg}$, participando com 47 a $83 \%$ do total. Somente para o $\mathrm{P}$, houve maior importância do gotejamento de copa. Isso demonstra a eficiente reciclagem de nutrientes da vegetação, 
que é uma adaptação para sua sobrevivência, especialmente no ambiente tropical (Vitousek, 1984).

No sistema agroflorestal, a reciclagem anual de nutrientes entre planta e solo foi de $154,4 \mathrm{~kg} \mathrm{ha}^{-1}$ de N, 12,4 $\mathrm{kg} \mathrm{ha}^{-1}$ de P, 75,8 $\mathrm{kg} \mathrm{ha}^{-1}$ de $\mathrm{K}, 93,0 \mathrm{~kg} \mathrm{ha}^{-1}$ de Ca e 34,0 kg ha ${ }^{-1}$ de $\mathrm{Mg}$. Os componentes vegetais foram mais importantes, pois participaram com 76 a $97 \%$ desse total. A reciclagem de N, Ca e Mg nesse sistema foi superior à adubação mineral recomendada nessas condições, para expectativa de produtividade média de grãos (Instituto Agronômico de Campinas, 1995). Salienta-se ainda, que esses valores foram 2,9 a 7,0 vezes superior ao cerrado.

A reciclagem de nutrientes foi subestimada, uma vez que não foi levado em conta a ação da fauna do solo. Os animais, principalmente os cupins, formigas e minhocas, movimentam grande quantidade de solo, trazendo para superfície os nutrientes, junto com o material do subsolo (Hole, 1981).

$\mathrm{O} P$ e o $\mathrm{K}$ foram os elementos menos disponiveis para a vegetação pois timham teores baixos a muito baixos no solo, além de serem significativamente removidos pela colheita.

Salienta-se ainda, a adição subestimada do nitrogênio nos dois sistemas, pois não foi contabilizada a fixação biológica. No caso da leucena, este processo pode representar $40 \%$ do elemento presente na fitomassa (Mulongoy \& Meersch, 1989). 


\section{CONCLUSÃo}

As perdas de nutrientes no cerrado foram baixas, sendo a lixiviação o mecanismo mais importante para os cátions, representando 46 a $96 \%$ do total. Esta perda foi superestimada, principalmente devido à ausência de raízes das árvores nos lisímetros. No sistema agroflorestal, a remoção através dos grãos foi o principal mecanismo de perda de nutrientes. Notou-se baixo escoamento superficial nos dois tratamentos, em função da cobertura permanente do solo.

A reciclagem interna de nutrientes ocorreu principalmente através dos componentes vegetais. A serapilheira no cerrado produziu $2176 \mathrm{~kg} \mathrm{ha}^{-1} \mathrm{ano}^{-1} \mathrm{de}$ fitomassa seca. No sistema agroflorestal, acumulou-se $11039 \mathrm{~kg} \mathrm{ha}^{-1} \mathrm{ano}^{-1}$ de matéria seca, sendo $40 \%$ proveniente da fitomassa podada, $38 \%$ dos restos culturais e $22 \%$ da serapilheira. Como resultado, teve-se uma reciclagem 2,9 a 7,0 vezes superior ao cerrado.

$\mathrm{O}$ balanço anual de nutrientes no cerrado foi de $8,5 \mathrm{~kg} \mathrm{ha}^{-1}$ de $\mathrm{N}, 1,4$ $\mathrm{kg} \mathrm{ha}^{-1}$ de P, 0,7 $\mathrm{kg} \mathrm{ha}^{-1}$ de $\mathrm{K},-15,5 \mathrm{~kg} \mathrm{ha}^{-1}$ de Ca e $-2,5 \mathrm{~kg} \mathrm{ha}^{-1}$ de $\mathrm{Mg}$. Os valores negativos representam perda contínua de cátions no sistema, resultando no empobrecimento do solo. Excetuando-se o nitrogênio, os demais nutrientes tiveram teores baixos a muito baixos no solo, sendo uma das principais limitações ao desenvolvimento da vegetação.

No sistema agroflorestal, o saldo anual de nutrientes atingiu $-12,8 \mathrm{~kg}$ $\mathrm{ha}^{-1}$ de $\mathrm{N},-2,6 \mathrm{~kg} \mathrm{ha}^{-1}$ de $\mathrm{P},-7,9 \mathrm{~kg} \mathrm{ha}^{-1}$ de $\mathrm{K},-23,3 \mathrm{~kg} \mathrm{ha}^{-1}$ de Ca e $-3,7 \mathrm{~kg} \mathrm{ha}^{-1}$ de $\mathrm{Mg}$. As perdas de nutrientes foram maiores que no cèrrado devido a remoção através dos grãos. Além disso, a adição de nitrogênio foi subestimada, pois não foi avaliada a fixação biológica. 
O principal benefício do cultivo em aléias foi o aumento nos teores de matéria orgânica, $\mathrm{N}, \mathrm{P}, \mathrm{Ca}$ e $\mathrm{Mg}$ na camada superficial do solo $(0-20 \mathrm{~cm})$, em comparação ao cerrado, devido à reciclagem continua através da fitomassa.

Apesar da melhoria de tais atributos, a produtividade das culturas foi baixa, sendo $1210 \mathrm{~kg} \mathrm{ha}^{-1}$ de milho e $175 \mathrm{~kg} \mathrm{ha}^{-1}$ de feijão. Isso foi atribuído à competição exercida pela leucena e à baixa disponibilidade de nutrientes no solo.

A adubação complementar, principalmente com fósforo e potássio poderia aumentar a produtividade das culturas e reverter o balanço de nutrientes. A adoção de podas mais frequentes iria diminuir a competição entre a leucena e as culturas, além de produzir uma fitomassa mais rica em nutrientes.

O cultivo em aléias pode ser recomendado para produção de alimentos sem a aplicação rotineira de fertilizantes, possibilitando economia de insumos para o agricultor. 


\section{REFERÊNCIAS BIBLIOGRÁFICAS}

BERTALOT, M.; PIAMONTE, R.; HARKALY, A. Sistema agrossilvopastoril no Instituto Biodinâmico. Agricultura Biodinâmica, v. 10, p.4-7, 1993.

BROWN, S.; ANDERSON, J.M.; WOOMER, P.L.; SWIFT, M.J.; BARRIOS, E. Soil biological processes in tropical ecosystems. In: WOOMER, P.L.; SWIFT, M.J. The biological management of tropical soil fertility. Chichester: John Wileu \& Sons, 1994. cap. 2, p.17-46.

CANTARELLA, H.; ABREU, C.A.; BERTON, R.S. Fornecimento de nutrientes pela matéria orgânica do solo: problemas e soluções. In: GUERRINI, I.A.; BÜLL, L.T. Encontro sobre matéria orgânica do solo: problemas e soluções, Bolucatu: Faculdade de Ciências Agronômicas/UNESP, 1992. p. 63-122.

CATCHPOOLE, D.W.; BLAIR, G. Forage tree legumes. I. Productivity and N economy of lecucuena, (iliricidia, (calliandra and Seshania tree/green panic mixtures. Australian Journal of Agricultural Research, v.41, n.3, p.521-30, 1990.

CHAGAS, J.M.; KLUTHCOUSKI, J.; AQUINO, A.R.L. Leucaena leucocephala como adubo verde para a cultura de feijão $\mathrm{em}$ cerrado. Pesquisa Agropecuária Brasileira, v. 16, n.6, p.809-14, 1981.

CONSTANTINIDES, M.; FOWNES, J.H. Nitrogen mineralization from leaves and litter of tropical plants: relationship to nitrogen, lignin and soluble polyphenol concentrations. Soil Biology and Biochemistry, v.26, p.49-55, 1994.

DELITTI, W.B.C.; SANTOS, A.L.P.; GARBER, V.R. Biomassa hipogéia da vegetação do cerrado. In: REUNIÃO ANUAL DA SOCIEDADE BRASILEIRA PARA O PROGRESSO DA CIÊNCIA, 38., Curitiba, 1986. Resumos. Ciência e Cultura, Suplemento, v.38, n.7, p.697-8.

DUGUMA, B.; KANG, B.T.; OKALI, D.U.U. Effect of pruning intensities of three woody leguminous species grown in alley croping with maize and cowpea on an alfisol. Agroforestry systems, v.6, p. 19-35, 1988. 
EMPRESA BRASILEIRA DE PESQUISA AGROPECUÁRIA. Serviço Nacional de Levantamento e Conservação de Solos. Manual de métodos de análise de solos. Rio de Janeiro: 1979. v.1.

FERNANDES, E.C.M.; DAVEY, C.B.; NELSON, L.A. Alley cropping on an acid soil in the upper Amazon: mulch, fertilizer and hedgerow root pruning effects. ASA Special Publication, v.56, p.77-96, 1993.

FERRARIS, R. Productivity of Leucaena leucocephala in the wet tropics of North Queensland. Tropical Grasslands, v. 13, n.1, p.20-7, 1979.

GOEDERT, W.J. Solos dos cerrados: tecnologias e estratégias de manejo. São Paulo: Nobel; Brasilia: EMBRAPA/CPAC, 1985. 422p.

GOTTSBERGER, I.S.; EITEN, G. Fitossociologia de um hectare de cerrado. Brasil Florestal. v. 54, p.55-70, 1983.

GREENLAND, D.I. The nitrogen cycle in West Africa. Agronomic considerations. In: ROSSWALL, T. Nitrogen cycling in West African Ecosystems. Stockholm: SCOPE/UNEP, 1980. p.73-81.

GUEVARRA, A.B.; WHITNEY, A.S.; THOMPSON, J.R. Influence of intra-row spacing and cutting regimes on the growth and yield of Leucuena. Agronomy Journal, v.70, p.1033-7, 1978.

HAGGAR, J.P.; WARREN, G.P.; BEER, J.W.; KASS, D. Phosphorus availability under alley cropping and mulched sole cropping systems in Costa Rica. Plant and Soil, v. 137, p.275-83, 1991.

HAGGAR, J.P.; TANNER, E.V.J.; BEER, J.W.; KASS, D.C.L. Nitrogen dynamics of tropical agroforestry and annual cropping systems. Soil Biology and Biochemistry, v. 25, n. 10, p. 1363-78, 1993.

HÖGBERG, P.; KUARNSTRÖM, M. Nitrogen fixation by woody legume Leucaena leucocephala in Tanzania. Plant and Soil, v.66, p.21-8, 1982.

HOLE, F.D. Effects of animals on soil. Geoderma, v.25, p.75-112, 1981.

INGRAM, J. The role of trees in maintaining and improving soil prodetivity. In: PRINSLEY, R.T. Agroforestry for sustainable production: economic implications. London: Commonweath Science Council, 1990. cap. 2, p.243-303.

INSTITUTO AGRONÔMICO DE CAMPINAS. Instruções agrícolas para o Estado de São Paulo. Campinas: 1995. 231 p. (IAC, Boletim Técnico, 200). 
INSTITUTO DE PESQUISAS TECNOLÓGICAS. Mapa geológico do Estado de São Paulo. São Paulo: IPT/Divisão de Minas e Geologia Aplicada, 1981. v.1.

JANZEN, H.H.; McGINN, S.M. Volatile loss of nitrogen during decomposition of legume green manure. Soil Biology and Biochemistry, v.23, n.3, p.291-7, 1991.

JORDAN, C.F.; HEUVELDOP, J. The water budget of an amazonian rain forest. Acta Amazonica, v.11, n.1, p.87-92, 1981.

KANG, B.T; WILSON, G.F.; SIPKENS, L. Alley cropping maize and leucaena in Southern Nigeria. Plant and Soil, v.63, p.165-79, 1981.

LAL, R. Losses of plant nutrients in runoff and eroded soil. In: ROSSWALL, T. Nitrogen cycling in West African Ecosystems. Stockholm: SCOPE/UNEP, 1980. p.31-8.

LAL, R. Agroforestry systems and soil surface management of a tropical alfisol: I: Soil moisture and crop yields. Agroforestry systems, n.8, p.7-29, 1989a.

LAL, R. Agroforestry systems and soil surface management of a tropical alfisol: II: Water runoff, soil crosion and nutrient loss. Agroforestry systems, v.8, p.97-111, $1989 \mathrm{~b}$.

LAL, R. Agroforestry systems and soil surface management of a tropical alfisol: III: Changes in soil chemical properties. Agroforestry systems, n.8, p.113-32, 1989c.

LANDSBERG, J.J. Nutrient dynamics and tree growth. In: LANDSBERG, J.J. Physiological ecology of forest production. London: Academic Press, 1986. p.11132.

LANGKAMP, P.J.; FARNELL, G.K,; DALLING, M.J. Nutrient cycling in a stand of Acacia holosericea A. Cunn. ex G. Don. 1. Measurement of precipitation, interception, seasonal acetylene reduction, plant growth and nitrogen requirement. Australian Journal of Botany, v.30, p.87-106, 1982.

LARA CABEZAS, W.A.R.C; TRIVELIN, P.C.O. Eficiência de um coletor semi-aberto estático na quantificação de $\mathrm{N}-\mathrm{NH}_{3}$ volatilizado da uréia aplicada ao solo. Revista Brasileira de Ciência do Solo, v. 14, p.345-52, 1990.

LEMOS, R.C.; SANTOS, R.D. Manual de método de trabalho de campo. Campinas: Sociedade Brasileira de Ciência do Solo, 1976, 36 p. 
LULANDALA, L.L.L.; HALL, J.B. Nutrient removals in havesting of Leucaena hedgerows at Mafiga, Morogo, Tanzania. Forest Ecology and Management, v.35, p.207-16, 1990 .

LUNDGREN, B.; NAIR, P.K.R. Agroforest for soil conservation. In: EL-SWAIFY, S.A.; MOLDENHAUER, W.C.; LO, A. Soil erosion and conservation. Ankeny: Soil Conservation Society of America, 1985. p. 703-717.

MALAVOLTA, E; VITTI, G.C.; OLIVEIRA, S.A. Avaliação do estado nutricional das plantas. Piracicaba: Associação Brasileira de Pesquisa da Potassa e Fosfato, $1989,201 \mathrm{p}$.

MEGURO, M.; DELITTI, W.B.C. O papel da precipitação na ciclagem de nutrientes minerais no campo cerrado de Mogi-Guaçu-SP. In: REUNIÃ̃O ANUAL DA SOCIEDADE BRASILEIRA PARA O PROGRESSO DA CIÊNCIA, 37., Belo Horizonte, 1985. Resumos. Ciência e Cultura, Suplemento, v.37, n.7, p.561.

MEGURO, M.; VINUEZA, G.N.; DELITTI, W.B.C. Ciclagem de nutrientes minerais na mata mesófila secundária. São Paulo. II. O papel da precipitação na importação e transferência do potássio e fósforo. Boletim de Botânica da Universidade de São Paulo. v.7, p.61-7, 1979.

MULUNGOY, K.; MEERSCH, M.K. Nitrogen contribution by leucaena (leucuena leacocephula) prunings to maize in an alley cropping system. Biology and Fertility of Soils, v.6, p.282-5, 1988

NASCIMENTO, C.M.; PEREIRA, M.A.M.G. Atlas climatológico do Estado de São Paulo (1977-1988). Campinas: Fundação Cargill, 1988, 93p.

NYATHI, P.; CAMPBELL, B. Leaf quality of Sesbania sesban, Leucaena leucocephala and Brachystegia spiciformis: potential agroforestry species. Forest Ecology and Management, v.64, p.259-64, 1994.

ONG, C.K.; CORLETT, J.E.; SINGH, R.P.; BLACK, C.R. Above and below ground interactions in agroforestry systems. Forest Ecology and Management, v.45, p.45$57,1991$.

PAINTER, R.B. Climatology and environmental measurement. In: CHAPMAN, S.B. Methods in plant ecology. Oxford: Blackwell Scientific Publications, 1976. p.369410.

PALM, C.A. Contribution of agroforestry trees to nutrient requeriments of intercropped plants. Agroforestry systems, v.30, p.105-24, 1995. 
PEREIRA, J; ; PERES, J.R.R. Manejo da matéria orgânica. In: GOEDERT, W.J. Solos dos cerrados: tecnologias e estratégias de manejo. São Paulo: Nobel; Brasília: EMBRAPA/CPAC, 1985. cap.10, p.261-84.

PERES, J.R.R.; SUEHT, A.R.; VARGAS, M.A.T.; DROZDOWICZ, A. Litter production in areas of brazilian cerrados. Pesquisa Agropecuária Brasileira, v. 18, n.9, p. 1037-43, 1983.

POMPÉIA, S.L. Aspectos dạ dinâmica dos nutrientes minerais em solo sob vegetação de campo-cerrado (Mogi-Guaçu-SP). São Paulo, 1989. 137p. Dissertação (M.S). Instituto de Biociências da USP.

QUEIROZ NETO, J.P. Solos da região dos cerrados e suas interpretações. Revista Brasileira de Ciência do Solo, v.6, n.1, p.11-2, 1982.

RAIJ, B.; QUAGGIO, J.A. Métodos de análise de solo para fins de fertilidade. Campinas, Instituto Agronômico de Campinas, 1983. 42p. (IAC, Boletim Técnico, 81 ).

RIZZO, J.A.; CENTENO, A.J.; LOUZA, J.S.; FILGUEIRAS, T.S. Levantamento de dados em áreas de cerrado e floresta caducifólia tropical do planalto Centro-oeste. In: FERRI, M.G. Simpósio sobre o cerrado. São Paulo: Editora Edgar Blücher, 1971. p.103-9.

SANCHEZ, P.A. Science in agroforestry. Agroforestry systems, v.30, p.5-55, 1995.

SANDHU, J.; SINHA, M.; AMBASHT, R.S. Nitrogen release from decomposing litter of leacaena leacocephala in the dry tropics. Soil Biology and Biochemistry, v.22, n.6, p.850-63, 1990.

SANTOS, P.F. Água de escoamento dos troncos e arquitetura arbórea. In: REUNIÃO ANUAL DA SOCIEDADE BRASILEIRA PARA O PROGRESSO DA CIÊNCIA, 40., 1988. Resumos. Ciência e Cultura, Suplemento, v.40, n.7, p.646.

SANTOS, P.F.; RODRIGUES, G.S. Avaliação de métodos para estimativa da decomposição do folhedo em ecossistema de cerrado (Corumbataí-SP). In: REUNIÃO ANUAL DA SOCIEDADE BRASILEIRA PARA O PROGRESSO DA CIÊNCIA, 34., Campinas, 1982. Resumos. Ciência e Cultura, Suplemento, v.34, n.7, p.559.

SANTOS, P.F.; RODRIGUES, G.S. Aporte de nutrientes minerais via precipitação pluviométrica em mata tropical subcaducifólia dos Planaltos do Paraná. In: REUNIÃO ANUAL DA SOCIEDADE BRASILEIRA PARA O PROGRESSO DA CIÊNCIA, 44., São Paulo, 1992. Resumos. Ciência e Cultura, Suplemento, v.44, n. 7, p.647-8. 
SETZER, J. Atlas climatológico e ecológico do Estado de São Paulo. São Paulo: Comissão Interestadual da Bacia Paraná, 1966.

SCHROTH, G. Tree root characteristics as criteria for species selection and systems design in agroforestry. Agroforestry systems, v.30, p.125-43, 1995.

SCHROTH, G.; OLIVER, R.; BALLE, P.; GNAHOVA, G.M.; KANCHANAKANTI, N.; LEDUC, B.; MALLET, B.; PELTIER, R.; ZECH, W. Alley cropping with Gliricidia sepium on an a high base status soil following forest clearing: effects on soil conditions, plant nutrition and crop yields. Agroforestry systems, v.32, p.261-76, 1995.

SEYFRIED, M.S.; RAO, P.S.C. Nutrient leaching loss from two contrasting cropping systems in the humid tropics. Tropical Agriculture. v.68, n.1, p.9-18, 1991.

SHANNON, D.A.; VOGEL, W.O; KABALVAPA, K.N. The effects of alley cropping and fertilizer application on continuously cropped maize. Tropical Agriculture, v.71, n.3, p.163-9, 1994

SINGH, R.P.; ONG, C.K.; SAHARAN, N. Above and below ground interactions in alley-cropping in semi-arid India. Agroforestry systems, v.9, p.259-74, 1989.

SSEKABEMBE, C.K. Perspectives hedgerow intercropping. Agroforestry Systems, v.3, n.4, p.339-56, 1985.

SZOTT, L.T.; FERNANDES, E.C.M; SANCHEZ, P.A. Soil-plant interactions in agroforestry systems. Forest Ecology and Management, v.45, p.127-52, 1991 a.

SZOTT, L.T; PALM, C.A.; SANCHEZ, P.A. Agroforestry in acid soils of the humid tropics. Advances in Agronomy, v.45, p.275-301, $1991 \mathrm{~b}$.

TEDESCO, M.J.; VOLKWEISS, S.J.; BOHNEN, H. Análise de solos, plantas e outros materiais. Porto Alegre: UFRGS, 1985. (Boletim técnico, 5).

VAN NOORDWIJK, M; HEINEN, M.; HAIRIAH, K. Old tree root channels in acid soils in the humid tropics: Important for crop root penetration, water infiltration and nitrogen management. Plant and Soil, v.134, p.37-44, 1991.

VITOUSEK, P.M. Litterfall, nutrient cycling and nutrient limitation in tropical forest. Ecology, v.65, n.1, p.285-98, 1984.

VITOUSEK, P.M.; SANFORD, R.L. Nutrient cycling in moist tropical forest. Annual Review of Ecology and Systematics. v.17, p.137-67, 1986. 
WANG, D.; BORMANN, F.H.; LUGO, A.E.; BOWDEN, R.D. Comparison of nutrientuse efficiency and biomass production in five tropical tree taxa. Forest Ecology and Management, v.46, p. 1-21, 1991.

WANG, I.J.; HSIA,Y.J.; HWANG, J.L.; KING, H.B. Long-term ecological research in Fushan forest. Hidrochemical cycles. In: PENG, C.I.; CHOU, C.H. Biodiversity and terrestrial ecosystems. Taipei: Academia Sinica, 1994. p.362-71. (Monograph series, No 14).

XU, Z.H.; SAFFIGNA, P.G.; MYERS, R.J.K.; CHAPMAN. A.L. Nitrogen cycling in leucaena (Leucuena leucocephala) alley cropping in semi-arid tropics. Plant and Soil, v.148, p.63-82, 1993.

YAMOAH, C.F.; AGBOOLA, A.A.; WILSON, G.F.; MULONGOY, K. Soil properties as affected by the use of leguminous shrubs for alley cropping with maize. Agriculture, Ecosystems and Environment, v.18, p.167-77, 1986. 